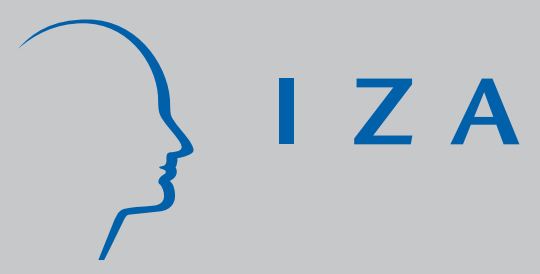

IZA DP No. 2348

Does School Tracking Affect Equality of Opportunity?

New Intemational Evidence

Giorgio Brunello

Daniele Checchi

September 2006 


\title{
Does School Tracking Affect Equality of Opportunity? New International Evidence
}

\author{
Giorgio Brunello \\ University of Padova, Collegio Carlo Alberto Torino, \\ CESifo and IZA Bonn \\ Daniele Checchi \\ University of Milano \\ and IZA Bonn
}

Discussion Paper No. 2348

September 2006

\author{
IZA \\ P.O. Box 7240 \\ 53072 Bonn \\ Germany \\ Phone: +49-228-3894-0 \\ Fax: +49-228-3894-180 \\ E-mail: iza@iza.org
}

Any opinions expressed here are those of the author(s) and not those of the institute. Research disseminated by IZA may include views on policy, but the institute itself takes no institutional policy positions.

The Institute for the Study of Labor (IZA) in Bonn is a local and virtual international research center and a place of communication between science, politics and business. IZA is an independent nonprofit company supported by Deutsche Post World Net. The center is associated with the University of Bonn and offers a stimulating research environment through its research networks, research support, and visitors and doctoral programs. IZA engages in (i) original and internationally competitive research in all fields of labor economics, (ii) development of policy concepts, and (iii) dissemination of research results and concepts to the interested public.

IZA Discussion Papers often represent preliminary work and are circulated to encourage discussion. Citation of such a paper should account for its provisional character. A revised version may be available directly from the author. 


\section{ABSTRACT \\ Does School Tracking Affect Equality of Opportunity? New International Evidence}

This paper investigates whether at the interaction between family background and school tracking affects human capital accumulation. Our a priori view is that more tracking should reinforce the role of parental privilege, and thereby reduce equality of opportunity. Compared to the current literature, which focuses on early outcomes, such as test scores at 13 and 15, we look at later outcomes, including literacy, dropout rates, college enrolment, employability and earnings. While we do not confirm previous results that tracking reinforces family background effects on literacy, we do confirm our view when looking at educational attainment and labour market outcomes. When looking at early wages, we find that parental background effects are stronger when tracking starts earlier. We reconcile the apparently contrasting results on literacy, educational attainment and earnings by arguing that the signalling role of formal education - captured by attainment - matters more than actual skills - measured by literacy - in the early stages of labour market experience.

JEL Classification: J24

Keywords: education, tracking, literacy, wages

Corresponding author:

Giorgio Brunello

Department of Economics

University of Padova

Via del Santo 33

35100 Padova

E-mail: giorgio.brunello@unipd.it

\footnotetext{
* Paper prepared for the October Panel Meeting of Economic Policy in Helsinki. We are grateful to the participants at the Turin conference on "Institutional Configuration, Schooling Choices, Labor and Financial Markets" and at the 2nd CSEFIGIER Symposium on "Economics and Institutions" for comments. We would like to thank the Editor in charge, three referees, Andreas Ammermüller, Gabriele Ballarino, Norberto Bottani, Bruno Losito, Lorenzo Rocco and Fabian Waldinger for helpful comments, and Ludger Wößmann for a useful discussion. Virginia Maestri provided competent research assistantship. This paper was prepared during visits at IZA-Bonn (Daniele Checchi) and Collegio Carlo Alberto in Moncalieri (Giorgio Brunello), which provided generous hospitality. The usual disclaimer applies.
} 
"Postponing the point in the educational career at which children enter different tracks and where educational decisions have to be made will improve the ability to anticipate future educational performance. The future to be anticipated is shorter and more experience with past educational performance is available to form respective expectations for the future. The working class should profit more from such measures because the upper classes will have better knowledge about educational requirements and more confidence to fulfil them from the beginning"

Breen et alt. 2005, p.9

"...vocational training is likely to be a two-edged in its appeal, as both incentives and diversion effects are simultaneously apparent in our results. [...] On the one hand, vocational training might contribute to increased training participation among those who would otherwise not continue into upper secondary education. On the other, young people in vocational training are less likely to invest any more in education and training than those in more general tracks"

Gangl, Müller and Raffe 2003, p.296.

"..the model of comprehensive schooling that grew up in the 1960s and 1970s is simply inadequate for today's needs... the keys are diversity not uniformity".

Morris quoted in Gorard and Smith 2004, p.17

\section{Motivation}

The quotes from eminent social scientists reported above well summarise the common opinion emerged after two decades of studies in the sociology of education. While initial studies focused mainly on secondary education, recent literature extends the analysis to school stratification at tertiary level (Arum, Gamoran and Shavit 2004). The key concept developed here is school stratification, considered as detrimental to educational achievement because it introduces fictitious barriers to further education. School stratification is viewed as a relevant institutional device reinforcing the intergenerational persistence in educational achievements across different social classes (Mare 1981).

More recently, few papers in the economics of education have reinforce this view (see Hanushek and Wößmann 2006, Ammermüller 2005, Schuetz, Ursprung and Wößmann 2005). In their analysis, the age of first selection into tracking and/or the number of track options available to the students is found to reinforce the impact of family background, and increase the dispersion in student achievements. While the large part of the sociological literature uses representative samples of adult populations and typically investigates educational attainment, the economic literature mainly relies on samples of students from international surveys, which measure literacy and numeracy at relatively early ages (13 or 15).

Our paper follow the line of research in the economics of education. We ask whether the effects of school design on inequality of opportunity are a temporary effect that can be detected when students are close to the tracking point or extend beyond that to the early part of adult working life. The question has relevance for policy, which is naturally more concerned about lasting effects. Therefore, we extend the analysis of the impact of school design on the role of parental privilege from 
the classrooms to the labour market, because we believe that one acid test of the quality of human capital accumulated at school is labour market returns (see Card and Krueger, 1990).

The empirical literature - see for instance the recent OECD PISA reports - has documented that one important reason of within country differences in educational attainment is family background. Since learning begets learning, initial differences in individual achievement at school due to parental education are likely to widen over time, as documented in a number of papers by Heckman and associates (see for instance Carneiro and Heckman, 2003). The influence of family background on schooling outcomes has implications both for efficiency and for equity. By restricting access to higher education, less privileged family background may reduce the investment in education below its efficient level. Since parental education is a circumstance beyond individual control, differences in outcomes generate inequality. The government can try to compensate poor background with publicly provided education, especially early on in individual life. For many, however, parental background is not itself open to policy influence in the short and medium run.

Another potential factor affecting schooling outcomes, which is potentially more amenable to policy influence, is school design. By school design we mean the institutional set-up that characterizes compulsory and post-compulsory education, starting from primary and ending with tertiary education. School design can affect outcomes directly, and can interact with parental background in determining individual choice. While under the heading of school stratification we can classify different institutional measures, going from grade repetition to creation of magnet schools, or from the development of a private schooling sector to curricula differentiation, we will focus on one important aspect of school design that has attracted considerable attention in recent years, first in the US and now in Europe, that is school tracking.

A school system is characterized by tracking when pupils are allocated, at some stage of their career between primary and tertiary school, to different tracks, which usually differ in the curriculum offered as well as in the average cognitive talent of enrolled students. While in the North-American context tracking is mainly ability grouping or streaming within a fully comprehensive schooling structure, in the European context tracking takes the form of well-defined separate segments in the education process, typically specializing in general and vocational education. Insofar that allocation to tracks is non random, school tracking introduces selection in the schooling process, which may take several forms, ranging from self selection to admission based on a test or on teachers' recommendations. In most cases, selection is affected, directly or indirectly, by family background. For instance, better-educated parents are more likely to enrol their offspring in a general track, which leads more naturally to university. On the other hand, blue-collar families may enrol an equally talented child in a more vocational curriculum. Even when the allocation is based on a formal test, pupils from bettereducated families are more likely to enter the academic track, either because cognitive ability could be 
partially incorporated in the genes or partially because it can be the product of the environment. With school selection, parental background can affect educational outcomes both directly, by influencing individual talent and resources, and indirectly, by conditioning the selection of pupils into different tracks - via parental pressure and lobbying. ${ }^{2}$

The policy question we ask in this paper is whether the influence of parental background on educational and labour market outcomes is affected by the design of the schooling system, with particular reference to school tracking. Suppose that comprehensive schooling reduces the influence of family background on educational outcomes. Then government policy which aims at increasing equality before labour market entry should prefer such system to a system which tracks students into different schools. The wave of comprehensive school reforms which have taken place in Europe since the early 1960 s - first in the UK and Italy, then in Scandinavia and most recently in Spain - was apparently motivated by the need to reduce the influence of privilege.

It is not at all obvious, however, that more comprehensive education also fosters efficiency. One potential merit of tracking is to separate pupils into more homogeneous classes, and any teacher knows that her job is much more effective in such an environment. The specialization effect of tracking can be further enhanced by the presence of non-linear peer effects, which increase average performance (see Minter Hoxby, 2000). At the same time, however, the allocation of pupils into tracks is far from noiseless, and the size of the noise is likely to increase the earlier the allocation occur (see Brunello, Ariga and Giannini, 2006 and Dustmann 2004). Furthermore, early specialization reduces versatility: in a rapidly changing economy, lack of versatility in the production of skills can generate relevant economic losses (see Ariga, Brunello, Iwahashi and Rocco, 2006).

We are not the first to investigate whether school design affects the relationship between parental background and educational outcomes. We introduce, however, two key differences with previous work: a) we employ a wider range of individual outcomes, including earnings and employment and literacy at adult age; b) alternative measures of school tracking. As briefly reviewed in the next section, previous empirical work has focused on individual test scores, taken at age 10,13 or at age 15 . We argue in the paper that these measures of individual outcomes are not fully satisfactory, insofar as they capture the impact of school design early on, without allowing the impact of schooling institutions to fully unravel. We elect instead to measure individual outcomes later on, when the relevant population has completed upper secondary education, and depending on the data at hand we select individuals in their late teens and early twenties, and often compare them with older workers. Our

\footnotetext{
2 There are additional dimensions along which students can be selected according to ability. Most European countries have introduced the possibility of having students repeat the same class if they are considered unfit for the following degree (Goux and Maurin 2006). The mere existence of final examination can induce self-selection by ability (Dee and Jacob 2006). Finally, the presence of private schooling may induce self-selection based on ability, especially when the public sector provides uniform standards of education for everyone (Stiglitz 1974), but recent empirical evidence on this is controversial (Vandenberghe and Robin 2004).
} 
measures of individual outcomes are educational attainment, literacy, employment and earnings. The underlying idea is that, if school tracking and family background matter, their economic effects should be more visible at the end of secondary school or in early labour market outcomes. This strategy follows Card and Krueger (1990), who study the impact of school quality on earnings rather than on test scores, as done for instance by Hanushek (1986). We also add to standard measures of school tracking - such as the time spent in a tracked school, the age of first selection or the number of available tracks - the share of the population tracked into the vocational stream, which, as shown in the theoretical model reported in the Appendix 1, captures the presence or absence of non-linear peer effects.

Our paper is organised as follows. In section 2 we review the existing literature in the economics of education which studies tracking and its interactions with parental background. In Section 3 we summarise theoretical results obtained in a formal model reported in Appendix 1, and present our measures of school design. Section 4 and Section 5 introduce the econometric strategy and the data. Section 6 presents the results. The policy implications are discussed in the final Section 7. 


\section{Previous research}

When reviewing the literature on the relationship between school tracking, family background and school outcomes, one needs to recognize that the word "tracking" means something rather different in Europe and the US. In Europe tracking refers to the presence of differentiated curricula, usually with an academic and a vocational emphasis, and students are assigned or self-sort into schools that specialize in each curriculum. In the US, tracking corresponds to ability streaming within a comprehensive school system, open to all American students.

Tracking itself has changed over time in a number of countries. The movement towards fully comprehensive school systems until the end of secondary level of education that occurred in some European countries during the sixties and the seventies (most notably in Sweden, Finland, England) has produced a reduction in the impact of parental background on children educational choice, which remains strong in systems where secondary schools are characterized by tracking (Germany, Italy, Switzerland). Most reforms were accompanied by the extension of compulsory education, which makes it difficult to decompose the contribution of each change. ${ }^{3}$

The empirical literature to date on the relationship between school tracking, family background and the production of human capital covers both country specific case studies and cross-national analysis. We briefly review some of these studies in the boxes reported below. Broadly, the empirical evidence based on country studies does not reject the idea that early tracking reinforces intergenerational persistence in educational attainment. Cross-country analysis also tends to conclude that tracking boosts educational inequality by strengthening the importance of parental background effects. The effects on average school performance appear to be less clear-cut. Overall, the message from this literature is that early school tracking is bad for equal opportunity, because it reinforces the role of household privilege in the quality and quantity of accumulated human capital.

Empirical research on the implications of school tracking is often bogged down by the lack of adequate data. The ideal dataset that any scholar would be eager to have consist of nationally representative longitudinal samples, collected over a sufficient number of countries and sufficiently long over time to guarantee an adequate number of educational reforms, possibly taking place at different dates. Needless to say, this dataset does not exist, and researchers have to compromise in some way or another. Typically, the studies in this area combine data from different surveys and pursue a difference-in-difference approach. They usually ignore temporal variation, since parental background and student information are collapsed for each country in a single snap-shot.

The papers by Schuetz, Ursprung and Wößmann (2005) and Waldinger, (2006) are the closest

\footnotetext{
${ }^{3}$ See the review of French, British and Swedish experience in Leschinsky and Mayer 1990.
} 
to ours in that they also ask whether cross country variations in school design can explain the observed cross country variation in the importance of parental background for schooling outcomes, typically measured by standardized test scores. Because of this, it is useful to consider these papers in more depth. Schuetz, Ursprung and Wößmann (2005) uses as a measure of schooling outcome the test scores of 13 year old pupils in over 50 countries and investigates whether this measure is significantly affected by the interaction of family background (number of books available at home) with an indicator of school design, the first age of selection into school tracking, conditional on a set of country dummies and on a number of possible confounding factors. They find that early tracking increases the impact of family background on test scores and exacerbate inequalities.

Waldinger (2006) focuses on the test scores of 15 year olds and uses a difference in difference approach, which consists of comparing outcomes for the treatment group, the 15 year olds students tested in the PISA experiment, and for the control group, the primary school pupils involved in the PIRLS tests. He finds no evidence that the interaction between school design and family background affects individual outcomes.

While we consider both papers very valuable contributions to this literature, looking at their potential drawbacks is useful to clarify where the empirical contribution of this paper lies. Both papers look at the impact of school design on test scores. While this is interesting, it might be somewhat limited when the issue at hand is whether secondary school design affects schooling outcomes. The sample used by Schuetz and co-authors cover the very young 13 year olds, who have still to start upper secondary education in most countries. With the exception of the countries with a very early tracking system (Germany, Austria, Hungary, Turkey, Czech Republic), tracking usually starts somewhat later, at 14 or 15. Similarly, the PISA sample used by Waldinger covers 15 year olds, who are in many countries only at the start of a tracking system. By choosing relatively early outcomes, both papers run the risk of not giving tracking enough time to work out its effects. One way to check this would be to look at later outcomes, such as for instance completion of secondary school or college.

These papers have also in common the fact that they exploit exclusively the cross-section variation in schooling institutions. This is prima facie reasonable, because these institutions vary slowly over time, and necessary with their cross-sectional data. However, the introduction of time variation would obviously help identifying the effects of schooling institutions on the outcome of interest. This could be done by considering for each country different cohorts of individuals, who were exposed to school at sufficiently different points in time. 


\subsection{Country case studies}

\section{Scandinavia}

Sweden introduced an educational reform in the 1950s, which increased compulsory education age, abolished selection by ability at age 12 and adopted a unified curriculum. Meghir and Palme (2004) use the fact that the reform was gradually implemented across municipalities, adopt a difference-indifference methodology for two cohorts, control for ability and family background, and show that the reform increased educational attainment and wages for the treated.

A similar reform introduced in Finland in 1972-73 is analysed by Pekkarinen, Uusitalo and Pekkala (2006). The age when tracking first occurs was shifted in Finland from 10 to 16 and the curriculum was unified. As for Sweden, the gradual introduction of the reform across municipalities allow the authors to use a difference-in-difference approach and estimate the degree of intergenerational mobility in male earnings. They find a significant decline in the autocorrelation coefficient. Since earnings and educational attainment are positively correlated, we interpret this finding as supportive of the view that the educational reform reduced the impact of parental background on children educational attainment. ${ }^{4}$

While Norway was already a late tracking country, it extended compulsory education by two years (from 7 to 9) during the 1970's, and unified the curriculum up to that point. Black, Devereux and Salvanes (2005) show that this reform was associated to an increase in educational attainment in the parent generation, but is silent on the potential link between father and child educational attainment.

\section{Germany}

Schnepf (2002) uses data from TIMMS 1995 and PISA 2000 to show that the early selection of German boys and girls into different tracks may be responsible for the lower average attainment and the larger variance recorded for Germany in this surveys. The data show that, although ability (proxied by test score) is a key allocation criterion in the tripartite system, educational achievement varies greatly within each school track.

Dustmann (2004) uses the panel component of the German Socio-Economic panel to investigate the correlation between secondary school choice and parental background (father and mother education and occupation). He estimates an ordered probit model for the type of secondary school completed ${ }^{5}$, and shows that the type of school attended a specific school type affects the entry wage. Both studies show that early selection (currently at the age of ten) could generate a poor allocation of talents.

\section{Great Britain}

Galindo-Rueda and Vignoles (2004) study the gradual transformation of British selective schools into a comprehensive system ${ }^{6}$ and show the increasing role played by parental background in student outcomes, together with a decline of the returns to ability. Using the National Child Development Survey, which has information on cognitive ability at ages 7 and 11, and the uneven implementation of the reform across areas, they conclude that comprehensive schools have reduced the performance of

\footnotetext{
${ }^{4}$ In a related paper, Pekkarinen (2005) explores the impact of the same reform on the educational attainment gender gap, and finds that postponement of the tracking age increased gender differences in the probability of choosing the academic secondary education and continuing into academic tertiary education. The reform had particularly negative effects on boys with a non-academic family background.

5 Dustmann 2004 follows the standard classification, which divides schools into secondary general schools (Hauptschule), intermediate schools (Realschule), and high schools (Gymnasium). In some lander (Berlin is a good example) comprehensive schools (Gesamtschule) are important, see the discussion in Schnepf 2002. A similar tripartite system (secondary modern school, technical school, and grammar school) existed in the early post-war period in the UK (see below).

${ }^{6}$ Until the 1960's England and Wales were characterised by a tri-partite system consisting of college-oriented 'grammar' schools, 'secondary modern' schools and a small and declining number of 'technical' schools. Students were selected into different tracks at the age of 11. The system wag gradually reformed during the 1970's.
} 
talented students, without substantial changes for low/middle ability students. In this perspective, the de-segregation of the English secondary system should have produced a compression in the distribution of educational achievements.

Their results have been questioned by Manning and Pisckhe (2006) on the basis of the pre-existing differences between LEAs which quickly shifted to the comprehensive school system and LEAs which resisted the reform, the former being systematically poorer and populated by children with lower previous achievement. These authors conclude rather sceptically that we know very little about the effect of comprehensive schooling in Britain.

\section{Switzerland}

Bauer and Riphahn (2006) use cantonal variations in the age of tracking interacted with parental education to show that late tracking reduces the relative advantage of children of better educated parents, thus supporting the findings by Dustmann (2004) for Germany.

\section{Netherlands}

Oosterbeek and Webbink (2004) investigate a reform which took place in the Netherlands in 1975, and simultaneously increased compulsory education and lengthened some of the vocational programmes. While track allocation was formally unaltered, there was a partial de-tracking of schools, because the reform reduced the curricular differences among tracks. The authors find that individuals attending lower vocational programmes do not benefit in terms of later wages from additional general education.

\section{Italy}

Students allocation to different tracks is studied by Checchi and Flabbi (2005), who compare Italy and Germany using the PISA 2003 dataset. ${ }^{8}$ These authors argue that, due to the lack of binding restrictions in the access to academic tracks in Italy (contrary to what applies in some German lander), sorting in the former country is driven more by family background (parental education and occupation, books at home) than by ability (test scores, grade repetition, previous marks), while the opposite occurs in Germany.

\section{United States}

Figlio and Page (2002) review the large literature on whether tracking by ability harms disadvantaged students. Their key point is that, since the allocation to tracks may be endogenous due to unobservable characteristics, the contribution of tracking to the dispersion in test scores can be overestimated. The authors also provide evidence that low achievers may even benefit from the availability of tracked schools. ${ }^{9}$ Notice that the notion of tracking in the US is different from the European notion, and is related to ability streaming within a formally comprehensive school system. In addition, the existence of large and identifiable minorities make the distinction between tracking and segregation rather ambiguous (see Oakes (1992)).

\footnotetext{
${ }^{7}$ Sorting by ability has not completely disappeared, especially after the quasi-market reforms introduced by in the 1980 's, which increased school incentives to attract good students. See the discussion in Noden 2000 and the references therein. Whether England secondary schools can currently be considered a two-tier system de facto is discussed in Taylor, Fitz and Gorard 2005.

${ }^{8}$ Here again we find a tripartite upper secondary school system based on vocational (istituti professionali), technical (istituti tecnici) and academic oriented high schools (licel). Differently from Germany, in principle all types of school give access to university, but transition rates are rather differentiated.

${ }^{9}$ Similar results are obtained by Betts and Shkolnik 2000 (see also their review of the literature on the argument).
} 


\subsection{Cross-country analysis}

Vandenberghe (2005) uses the test scores of 15-year-old students in PISA 2000 and asks whether alternative measures of school stratification (extent of tracking - measured by the percentage of pupils attending vocational and prevocational programmes, repetition - measured by the percentage of students attending a grade inferior to the modal one, interschool segregation - measured by the standard deviation of school mean scores) affect either the mean or the dispersion of test scores. He concludes that the only measure slightly affecting dispersion is school segregation.

School segregation is also the focus of the analyses conducted by Gorard and Smith (2004) and by Jenkins, Micklewright and Schnepf (2006). The first paper is based on PISA 2000 survey and provide different measures of school dissimilarity indices for $15 \mathrm{EU}$ countries. ${ }^{10}$ The second paper extends the analysis to all the countries included in PISA 2000 and PISA 2003 surveys. They explore the decomposition of the dissimilarity index in order to account for the differences in segregation that may be attributable to the public/private divide and to the existing degree of parental choice.

Entorf and Lauk (2006) also use PISA data and consider a specific form of social exclusion related to the status of migrant (defined as child of foreign born parents). They study the group specific peer effect among subgroups of natives and migrants, and also the spill-over effect among groups (so-called 'social multiplier'), finding that in tracking countries (Austria and Germany) group-specific peer effects are stronger than in comprehensive school countries (the Scandinavian ones). ${ }^{11}$

Hanushek and Wößmann (2005), combine six surveys (TIMMS 1995, 1999, 2003, PISA 2000 and 2003, PIRLS 2001) so as to have two observations by country, one before tracking takes place $\left(4^{\text {th }}\right.$ grade) and the other after it has taken place in countries with early tracking $\left(8^{\text {th }}\right.$ grade). ${ }^{12}$ They measure tracking with a dummy equal to 1 when tracking takes place before or after the $8^{\text {th }}$ grade, and to zero otherwise. After controlling for initial conditions, they find no clear evidence that tracking affects average performance and clearer evidence that it increases the dispersion in test scores. They also show that low-performing students are those who are most damaged by early tracking.

Ammermüller (2005) considers four potential sources of inequality in student performance: the number of school tracks available at $9^{\text {th }}$ grade, annual instruction time, the share of students in private schooling and school autonomy (only available for cross-section analysis in PISA). By combining data from two surveys (PISA and PIRLS) he studies whether the correlation between student performance and parental background (proxied by parental education and social prestige, books available at home and language spoken at home) is affected by one or more measure of school stratification. He finds that the number of tracks has increases inequality since "...the choice of schools seems to benefit socially advantaged students, who have easier access to better schools. This also holds for the size of the private school sector, which is positively linked to the effect of books at home."13

\footnotetext{
10 They compute segregation indices (defined as the 'proportion of disadvantaged students - bottom $10 \%$ of the distribution - who would have to exchange schools within the area of the analysis, for there to be an even distribution of this group among the population'), dissimilarity indices and Gini indices by sex, parental occupation, foreign origin and ability. The indices are pairwise highly correlated and give an almost identical ranking of countries; tracking countries, like Germany or Belgium, come out among the most segregating educational systems in their sample, while Nordic countries are the least segregated (due to their catchment policy).

11 They interpret their results in a causal way after showing that the estimated coefficients on peer effects do not change significant when they exclude the schools where the head of school declare that selection on ability is applied on application. 12 The comparability of different surveys (as if they were random draws from the same distribution) is the implicit assumption of this and the following papers (see Fertig 2004a). A comparison of central moments between PISA, PIRLS, TIMMS and IALS suggest that all these surveys depict a similar picture in terms of country ranking: see Brown et al. 2005. ${ }^{13}$ Ammermüller 2005, p.25.
} 
Analogous conclusions are reached in Schuetz, Ursprung and Wößmann (2005). They use data from TIMMS and TIMMS-Repeat to provide an estimate of inequality of opportunity based on the correlation between parental education (proxied by the number of books at home) and student achievement. This measure is correlated with schooling institutions, including the age of first tracking, the duration of pre-primary school and the enrolment in pre-primary education (the latter variable exhibiting an inverted U-shape relationship). Their main results confirm the predictions of their theoretical model: "There is a negative relationship of the FBE [family background effect] with age of first tracking and preschool duration, and an inverted U-shaped relationship between FBE and preschool enrolment. In the country-level model ..., these features of the education system can together account for 40 percent of the cross-country variation in our estimated FBEs." 14

These results have been challenged by Waldinger (2006), who questions the causal link between the selected measure of tracking, parental background and student outcomes. His main argument is that even in comprehensive systems with family choice there may be a spontaneous tendency to self select according to ability or family background (through residential segregation, use of private sector, choice of subjects). He applies a difference-in-difference approach using PISA 2000, PIRLS 2001, TIMMS 1995 and 1998 surveys, and he finds no significant effect of tracking on the relationship between parental background and school outcomes.

\subsection{Our contribution}

Our investigation of the relationship between schooling institutions, parental background and educational outcomes innovates with respect to the previous literature in three directions. First, we look at a much broader list of indicators of school performance, well beyond the standardized test scores taken early on in schooling life. This list includes educational attainment, enrolment in college and literacy, which pertain directly to school outcomes, but also more indirect indicators, which measure early labour market performance, such as employment, training and wages. The underlying idea is that, if school tracking and family background matter, their economic effects should be more visible at the end of secondary school or in early labour market outcomes.

Second, we introduce time variation by looking at two different cohorts of individuals, who have been at school at some distance from each other. For each cohort, we have data on schooling outcome, family background, and schooling institutions, which we reconstruct by going back two decades (mid 1980s and mid 1990s). We believe that by so doing we add to the cross-country variation some genuine temporal variation, which obviously relies on the variation of schooling institutions over time. We are also aware that by so doing we face an important trade-off. If we want to maximize the number of countries, then we should proceed as Schuetz and co-authors (2005), and focus on the standardized test scores of 13 or 15 years old students. If we want to look at schooling outcome later on in life, then the number of countries with available data falls dramatically by half, from close to 50 to close to 25 . To this we can partially remedy by adding genuine time variation.

\footnotetext{
${ }^{14}$ Schuetz, Ursprung and Wößmann 2005, p.24.
} 
Third, we develop theoretical models which justify the inclusion of two indicators of school tracking, the length of time spent in tracked schools and the percentage of students enrolled in vocational tracks. While the former indicator has been used previously, the latter indicator has been ignored, but has potentially interesting implications for the presence - or absence - of non-linear peer effects in schools.

\section{Theoretical insights}

As recently summarized by Manning and Pischke (2006) "..at a theoretical level, there are good arguments for selection as well as for comprehensive education. The main argument for selection or tracking is presumably that it is much easier to teach lower variance classes. Since teachers can focus on the ability level of particular groups of students, students of all ability levels might benefit from selection. One argument against selection is that there might be positive peer effects from the most able students. By tracking these students into separate classrooms, the most able students may benefit from being with each other. However, the lower ability ranges loose from not having this peer group around. We know very little about the different impact of peer group effects on different types of students empirically, so it is difficult to judge a priori whether this leads to lower or higher average performance in a selective system".

Clearly, there are both efficiency and equity arguments for school tracking. Higher school effectiveness in lower variance schools is an efficiency argument. Peer effects increase efficiency if they are non-linear. Quoting Hoxby and Weingarth (2005).."if peer effects were linear in means, then regardless of how peers were arranged, society would have the same average level of outcome...Moreover, most applications of peer effects....need to have non-linear peer effects to generate results that are interesting and that mimic the facts." (p.3). The presence of peer effects has also equity implications if ability tracking concentrate students from less privileged parental background in the lower ability tracks.

There is no consensus in the empirical literature on the existence and/or size of peer group effects. The US evidence to date is also mixed. Many find weak or non - existent peer effects. Recent work, including Hoxby (2000) and Sacerdote (2001), find instead evidence of positive peer effects. In a recent study employing Chinese data, Ding and Lehrer (2006), find not only that peer effects exist, but they are highly non-linear. Turning to Europe based studies, Ammermüller and Pischke (2006) find significant peer effects in the primary school classes of 6 European countries, even after taking into account self-selection based on family background and measurement errors. Schneeweis and WinterEbmer (2005), study the existence of peer effects in the Austrian sample of the PISA 2000 survey, and find a positive contribution of the peer socio-economic background at school level, especially for low- 
ability students, while social heterogeneity has a small negative effect. By combining the two results, the authors argue in favour of reallocating students within school types. In the same vein, Goux and Maurin (2006) identify neighbourhood effects produced by other teenagers living in close proximity, and find significant effects on the probability of grade repetition at the end of junior high school.

In the two models presented in the Appendix 1, we show that the nature of peer effects is also relevant for the issue at hand - whether school tracking affects in a significant way the impact of parental background on school outcomes and equal opportunity in education and the labour market, which we call the family background effect (FBE), in line with Schuetz and co-authors. The first model sets the preliminary stage and in the spirit of Benabou (1996) shows that whether ability types are complements or substitutes in the production of the peer effect is relevant both for average human capital and for the impact of tracking on the family background effect.

The latter model is designed more specifically to address the issue discussed in this paper, and draws from previous work by Brunello, Ariga and Giannini (2004). We consider a schooling system ranging from primary to upper secondary education - college can be fitted in at some additional cost. Depending on the schooling institutions in place, at some stage schools are separated into two tracks, a general and a vocational track. The allocation of pupils to tracks depends on a mixture of parental choice, ability testing and recommendation by teachers.

A key tenet in this literature is that parental background affects school performance both directly - because ability is partly in the genes - and indirectly, because households with "good" parental background are more likely to have their offspring admitted to the general track, which is expected to provide better education.

If the children of less privileged households are more likely to end up in vocational tracks, and the quality of the education offered by these tracks is lower than in general tracks, then the gap in schooling performance between these pupils and the pupils of more privileged households is going to increase the longer the time spent in each track, which explains why the literature focuses on an indicator of tracking length.

Each track produces human capital by combining a) individual ability; b) the peer effect, which is the average ability of the pupils enrolled in the track. The academic track attracts more talented pupils, and has a higher peer value than the vocational track. If peer effects are linear, the increase in individual human capital in the academic track - associated to a higher peer effect - should exactly compensate the reduction in individual human capital in the vocational track - associated to a lower peer effect there. Non-linearities in the peer effect imply instead that re-allocating students across tracks affect the average or expected outcome.

We allow peer effects to be non-linear. We also model parental background as a component of individual ability: the better the background, the higher individual talent. While this is a convenient 
short-cut, it captures well the important role played by household characteristics in the development of talent in the initial steps of life. Therefore, parental background affects allocation to tracks by affecting individual ability.

With this simple model in hand, we can compute the family background effect, that is, the increase in average human capital associated to an increase in average parental background. It turns out that the contribution of family background depends on tracking length, on the impact of the peer effect in each track and, in the presence on non-linear peer effects - on the share of pupils allocated to the less prestigious track. The reason for the latter effect is simple. While a good background is instrumental to the allocation of the pupil to the academic track, such allocation depends also on the availability of slots. When only a few slots are available in the academic track, even students from privileged households end up in vocational tracks, where the peer effect is lower.

This simple model focuses on two tracking indicators: a) tracking length, or the time spent in a stratified school; b) the share of individuals in the vocational and less prestigious track, which matters in the presence of non-linearities. We can use the model to study how the family background effect (FBE) varies with changes in both indicators. Does family background matters more for schooling when tracking is longer? The answer is that more tracking affects positively FBE if the contribution of the peer effect to human capital is higher in the academic track of a stratified school than in a comprehensive school which has no tracks - a specialization effect. When the peer effect is non-linear, however, the answer depends also on the share of students in the vocational track, because an increase in such a share reduces the number of slots in the top track, and the room of manoeuvre for privileged households.

\subsection{Available measures of sorting}

The empirical literature which has investigated how parental background and school design affect individual school performance has used alternative indicators of school tracking. Hanushek and Wößmann (2005), for instance, measure tracking with the age at which tracking takes place. Since performance is measured at the same age (15 for PISA and 13 for TIMMS), the inclusion of the age of first selection in a cross-country set-up captures the length of time spent in a diversified system. Ammermüller (2005) uses instead the number of tracks a schooling system has when the students are in lower secondary education. This measure, however, fails to capture how many years a student spends in a track. Waldinger (2006) measures tracking with the minimum school grade at which a significant proportion of students are educated in a different type of school. He then defines an early tracking threshold, which indicates whether a country tracks students early or late.

Our theoretical model has two implications: the family background effect FBE on human capital is affected both by the extent of time spent by an (average) student in tracked schools, and by 
the share of students allocated to the vocational track. The latter variable matters only when peer effects are non-linear. Needless to say, we can think of other confounding variables which can also affect FBE. For instance, where schools are comprehensive, sorting may occurs along different dimensions, such as the public-private divide. Family background could also interact with the resources invested in education, such as the share of public expenditure in education over GDP or the studentteacher ratio in secondary education. Following Schuetz, Ursprung and Wößmann (2005) we also consider the percentage of the student population enrolled in pre-primary education, which in their model has a non-linear effect on the FBE. ${ }^{15}$

Table 1 reports our main indicators of tracking for the majority of OECD countries at three discrete points of schooling time, 1985, 1995 and 2002, while the Appendix 2 reports data sources and additional variables for the same educational systems. The age of first selection into tracks (first three columns) has remained unchanged over time in the vast majority of the selected countries, because the major comprehensive school reforms have taken place in the sixties and seventies. Important exceptions are Spain, with the LOGSE reform of 1990, which delayed tracking from 14 to $16^{16}$, the Czech Republic, which anticipated it from 15 to 11 in the early 1990 by allowing pupils to complete compulsory education using either normal school or the gymnasium, and the Netherlands, which introduced in 1993 an additional year of compulsory education, raising the separation into tracks at the age of 13. The second group of three columns reports the length of school tracking, our empirical counterpart of variable $\tau$ in the theoretical model, which measures the percentage of time in primary and secondary school spent in a tracking regime and ranges between zero and one. ${ }^{17}$ Finally, the third group of three columns illustrates the percentage of students enrolled in vocational education in upper secondary education, which ranges from 0 in the US and Canada, where schools are entirely comprehensive ${ }^{18}$, to more than 70 percent in Austria and Germany. ${ }^{19}$

Table 2 reports pair-wise correlations of our selected variables. While it is obvious that time spent in tracked curricula is correlated with the share of student in vocational tracks, it is less obvious that both variables positively correlate with pre-primary enrolment. In addition, pre-primary schooling

\footnotetext{
${ }^{15}$ We have also collected data on other dimensions of student sorting, such as the age of start and end of compulsory education, the share of students under tracking in lower secondary education, the repetition rate at secondary level, the number of tracks available at secondary and tertiary level, the share of students in tertiary vocational education (ISCED 5B), but the coverage and/or the high correlation with other selected variables have advised to leave them out of the analysis. ${ }^{16}$ We are grateful to Laura Romero for helping us with the Spanish institutional setup.

${ }_{17}$ This variable is constructed as the ratio of $(t-s)$, where $t$ is age at the end of upper secondary education and $s$ is the age of first selection (column 1 to 3 ), to $(t-p)$, where $p$ is the age of primary education start. One may object that since $t$ varies across countries, we are not comparing countries on an identical basis (as it could be the case if $t$ were set equal to 18 for all countries). However, educational achievement is mainly relative to the neighbouring population, and therefore is country specific. For this reason, we have preferred our definition, also because the variation is limited: in the mid 90's the end of secondary school ranges from 17.5 (Ireland, Netherlands and Russian Federation) to 19.5 (Denmark, Switzerland).

${ }^{18}$ However, ability streaming within comprehensive institutions is widespread in the US.

${ }^{19}$ We were forced to group "pre-vocational" and "general" secondary school enrolment, because our OECD data source merged the two definitions into one around mid 90's.
} 
is also positively correlated with public expenditure in education. Overall, the low level of correlation between these variables is reassuring of the fact that we are capturing different features of the educational systems in these countries.

\subsection{Advantages and limits of our measure}

There are two types of problems in our research strategy. The first is related to the classification of institutions. At the best of our knowledge, there is no official data source providing institutional information that is consistently comparable across countries and years. ${ }^{20}$ Especially for initial years (remember that we wanted information on educational systems at least in the mid 1980s), we were forced to go to paper sources, and to reconstruct institutional details from country case description and/or visual inspection of charts describing different educational systems. The risk of measurement errors due to arbitrary classification is clearly high. The second problem is related to school participation data. In some cases, we have found different numbers from different sources with respect to secondary school participation. ${ }^{21}$ For reasons of comparability we have decided to stick to a unique data source, the OECD Education Database, which ensures the largest country/year coverage. However, by inspecting the time series of the relevant variables we suspect that some change of definitions has occurred between the first and the second period for a few countries (notably vocational education share in Belgium in 1991 and Australia in 1993) but also between the second and the third period (also vocational share in Hungary in 1998, Italy in 2000). We believe that the cost in terms of comparability of using alternative national data sources is likely to be higher than the advantage of having an international dataset, especially if we take into account the fact that we always control for country/year fixed effects in the regressions. Therefore, our data on pre-primary education, vocational enrolment and private school participation are all extracted from the same dataset.

\section{The Econometric Approach}

It is very difficult to evaluate the impact of variation in educational systems (notably school reforms) on individual outcomes. As argued by Palme and Meghir (2005) these reforms are implemented nationally and often at once, implying that one should rely on before and after comparisons, which may confound the effects of policies with other macro-aggregate and cohort

\footnotetext{
${ }^{20}$ Eurydice (www.eurydice.org) is a rich source of information on institutional details about educational systems, but unfortunately cover only European countries, and in some cases lacks of retrospective information. The Unesco World Higher Education Database (http://www.unesco.org/iau/onlinedatabases/index.html) has a larger country coverage, but it spans only 7 years. The well-known OECD publication Education at a glance was started only in 1996, and is not very rich on institutional details.

${ }^{21}$ For example, according to Eurostat the share of students in vocational secondary education in Belgium in 1985 is 64.8 , while in OECD database the same number is 48.7; similarly corresponding figures for Greece are 28.3 and 32.8 , for Netherlands 66.1 and 52.1, for Portugal 27.0 and 10.2.
} 
effects. We start from the baseline specification

$$
Y_{i j k}=\delta_{j k}+\alpha X_{i j k}+\beta_{1} F B_{i j k}+\gamma F B_{i j k} T_{j k}+\varepsilon_{i j k}
$$

where $Y$ is the outcome of interest, $\delta$ are dummies (country $(k) \times \operatorname{cohort}(j)), X$ is a vector of individual controls, $F B$ is the indicator of family background, and $T$ is a (vector of) school tracking indicator(s). This specification omits the direct effect of school design on individual outcomes, which are affected by a host of country specific and (country $\times$ wave) specific confounding factors. With the data at hand, we cannot hope to discriminate these factors from the influence of schooling. By focusing instead on the impact of schooling institutions on the slope of the relationship between $Y$ and $F B$, we reduce the bias attributable to omitted country-specific variables, the impact of which is captured by unrestricted country and country $\times$ cohort dummies ${ }^{22}$. The underlying idea is that the structure of schooling can alter the relationship between household characteristics and individual outcomes, or the family background effect.

As remarked by Waldinger (2006), however, the inclusion of country dummies does not preclude the possibility that the schooling indicator $T$ be correlated with unobserved country variables, and that these variables affect the relationship between $Y$ and $F B$. If this is the case, the estimate of $\gamma$, our parameter of interest, would be biased. Waldinger controls for these unobservables by using a difference in difference technique. We choose a different strategy, which exploits the variation across countries and over time in school design, and consists of adding to the set of explanatory variables the interaction of family background with potential confounding factors $C_{j k}$, as in equation (2)

$$
Y_{i j k}=\delta_{j k}+\alpha X_{i j k}+\beta_{1} F B_{i j k}+\beta F B_{i j k} C_{j k}+\gamma F B_{i j k} T_{j k}+\varepsilon_{i j k}
$$

and as done by Schuetz, Ursprung and Wößmann (2005). ${ }^{23}$ Our confounding factors are enrolment in pre-primary schools, enrolment in private schools, the student-teacher ratio and public expenditure in education. All these confounding factors have been found in the literature to be correlated with various measures of educational attainment.

Since the schooling indicator in equation (2) is measured at the country by cohort rather than at

\footnotetext{
22 A similar approach is discussed by Card and Krueger 1996a, in the literature of the impact of school quality, and more recently by Schuetz, Ursprung and Wößmann 2005.

${ }^{23}$ Since our measures of school design vary both across countries and over time, we could interact family background with country dummies, and control for all time invariant confounding factors, which affect the relationship between family background and the selected outcomes. By so doing, however, we would not be able to distinguish the contribution of the cross-country variation of school design. With only two points in time, it is likely that such variation in school design takes up the bulk of the total variation in our indicator.
} 
the individual level, we allow the error term to be independent across countries and cohorts and interdependent within each combination of country and cohort. This means that we treat the standard errors as if there were only as many observations as there are combinations of countries and cohorts in the regression. Similarly, we abstract from survey specific weights (when available), and use weighed regressions, where weights are designed to give to each country in each wave the same weight.

We are aware that the estimated coefficients in (2) can be affected by the potential endogeneity of the regressors. In facts, let us decompose the error term in (2) as follows

$$
\varepsilon_{i j k}=u_{i}+u_{j k}+\eta_{i j k}
$$

where the $u$ components are individual and country by cohort effects, and the residual $\eta$ is assumed to be orthogonal to the regressors in (2). Consider first the individual effect. As discussed by Card and Krueger (1996b) such effect could capture unobserved individual ability, which is correlated both with individual outcomes and with parental background, because ability can be genetically and/or culturally transmitted. In such a case, the estimated coefficients are biased. However, in the case where this ability bias is invariant across countries and cohorts we can consider our estimates of $\gamma$ as informative of the relationship between the family background effect and school design. We are unable to think of factors that may systematically affect this potential bias, either across countries or over time, and therefore we hold our estimates as informative of the impact of school design on the equality of opportunity, as measured by the relationship between family background and educational attainment.

Next let us consider the country by cohort component $u_{j k}$, which has the same level of aggregation as our indicator of school tracking, and assume for instance that our dependent variable $Y$ is individual educational attainment. This component can be interpreted as a country $\times$ cohort innovation to attainment, which can be correlated with the distribution of students between school types. In such a case, our tracking indicator $T$ and educational attainment would be driven by a common factor, and our estimates would be distorted. Our remedy to this is to capture all country by cohort effects with country by cohort dummies. 


\section{The Data}

\subsection{Description}

As stressed in the introduction to this paper, we are interested in studying the impact of the design of schooling institutions on the relationship between family background and the education and early labour market outcomes of young adults. For this purpose we need data that are representative of national populations, and contain at the same time a sufficient number of countries to allow for sufficient variation in schooling institutions. We identify four datasets with the required characteristics: a) the European Community Household Panel (ECHP), a comparative panel covering 15 European countries and spanning 8 years, from 1994 to 2001. The ECHP is based on a fairly uniform questionnaire, and explicitly designed to favour international comparisons. Individuals in this survey are interviewed once they reach age 16. In order to disentangle age and cohort effects, we use the time span of the panel to extract from these data two cohorts of individuals, those aged 20 to 24 in 1995 and those aged 20 to 24 in 2000. ${ }^{24}$ While the first cohort was born between 1971 and 1975, and went to upper secondary school between 1985 and 1994, the second cohort was born between 1976 and 1980 and went to high school between 1990 and 1999. The two schooling periods partly overlap, but not entirely so, and we assign to the former cohort the schooling institution indicators for the mid 80s and to the latter cohort the institution indicators for the mid 90's. Needless to say, this assignment is rather extreme, and perhaps exaggerates the variation occurring between the two cohorts. The advantage of using ECHP is that is allows us to construct two separate cohorts of individuals with the same age. One disadvantage is that the information on family background is not immediately available, and need to be constructed by linking households over time. This exercise generates important attrition in the data ${ }^{25}$.

The second dataset we use is the International Social Survey Programme (ISSP), a repeated cross-country survey of the adult population, in place since 1985, with a variable number of countries in each year. The survey contains information on maximum educational attainment (with countryspecific coding), occupational status and earnings. In some surveys there is also information about parental education and job satisfaction. In order to extract from these data two different cohorts of the same age, who went to school in different years, with a sufficient time lag between them, we have selected the 1991 and the 1999 surveys. ${ }^{26}$ In this way we identify two age cohorts, both aged between

\footnotetext{
24 The age range of the cohorts is dictated by the need to avoid having the same individuals in both cohorts.

${ }_{25}$ D'Hombres and Brunello, 2005, illustrate in detail the pros and cons of using family background in the ECHP, and present evidence that the endogenous selection problems originated by the construction of the data are not serious.

26 The most recent wave reporting information on parental education is 1999, which includes 25 countries (Australia, Austria, Bulgaria, Canada, Chile, Cyprus, Czech Republic, France, Germany, Hungary, Israel, Japan, Latvia, New Zealand, Norway, Philippines, Poland, Portugal, Russian Federation, Slovakia, Slovenia, Spain, Sweden, United Kingdom and United States). A 10-year time lag between surveys would have been ideal, but the 1989 survey contains too few countries with valid information on parental education (Austria, Hungary and United States). Therefore we have selected the 1991 survey, which includes 16 countries (Australia, Austria, Germany, Hungary, Ireland, Israel, Italy, Netherlands, New Zealand, Norway, Philippines, Poland, Russian Federation, Slovenia, United Kingdom and United States).
} 
18 and 24 (included), who were born in the periods 1967-1973 and 1975-1981 respectively, and went to secondary school during 1981-1992 and 1989-2000. Non-missing information on parental education and school stratification reduces the available sample to 5 countries (Australia, Germany (both East and West), Hungary, Poland and United States). In order to increase the number of countries, we combine these two datasets, obtaining a sample of 33.132 observations covering 16 countries. $^{27}$ The age restriction makes this sample more appropriate for the investigation of youth behaviour at labour market entry, but less appropriate for investigating educational attainment, since in some countries college completion occurs at a later age. Descriptive statistics for this sample are reported in Table 3.

We also generate data for two subsequent cohorts, using the International Adult Literacy Survey (IALS), which investigate the prose, document and quantitative literacy of adults in a sample of OECD countries, and ISSP. The countries included in IALS ${ }^{28}$ have conducted their surveys at different points in time, some in 1994, some in 1996 and the rest in 1998. An advantage with respect to ECHP is that it provides data on parental education on a representative scale. Our requirement to identify the two subsequent cohorts is that either cohort went to school in a different period, when the school indicators take different values. Because of the different dates of the interviews, we select different age groups: the age groups 17-22 and 27-32 for the countries which carried their surveys in 1994; the age groups 18-24 and 28-34 for the surveys undertaken in 1996; the age groups 20-25 and 30-35 for the surveys taken in 1998. In the first case, the younger cohort was born between 1972 and 1977, and went to high school during the period 1986-1996. The older cohort was born and went to school ten years later. In this case, there is overlap between the two cohorts, and we attribute to the former cohort the schooling institutions of mid 80's and to the latter cohort the institutions of mid 90's.

We use a similar methodology for the 1999 ISSP survey, and identify two age cohorts, aged 1824 and 28-34, which were born in 1975-1981 and 1965-1971 respectively, who went to upper secondary school during 1989-2000 and 1979-1990. We associate the former cohort to the schooling institutions of the mid 1990s, and the latter cohort to the institutions of the mid 1980s. Following this alternative route, and excluding missing information on parental education (missing for Austria, Bulgaria and United Kingdom), ${ }^{29}$ or on school stratification (missing for Cyprus), we are left with 21 countries (Australia, Canada, Chile, Czech Republic, France, Germany, Hungary, Israel, Japan, Latvia, New Zealand, Norway, Philippines, Poland, Portugal, Russian Federation, Slovakia, Slovenia, Spain, Sweden,

\footnotetext{
27 The countries are Austria, Belgium, Denmark, Finland, France, Germany, Greece, Ireland, Italy, Portugal, Spain, United Kingdom from ECHP and Australia, Hungary, Poland and United States from ISSP 1991-99. Sweden and the Netherlands are excluded from ECHP due to missing observations on parental background in one wave; Germany is excluded from ISSP in order to avoid overlapping with ECHP. Slovenia is retained, but data on school institutions are absent.

${ }_{28}$ Countries are Belgium, Chile, Czech Republic, Denmark, Finland, Germany, Hungary, Ireland, Italy, Netherlands, New Zealand, Norway, Poland, Slovenia, Sweden, Switzerland, United Kingdom and United States.

${ }^{29}$ It is worth recalling that in addition to the question about father and mother educational attainment, the 1999 survey contains a question about "how many books did you have at home when you were 15". We have explored the significance of this alternative representation of family background, but in general it is less significant than maximum parental education.
} 
United States). By combining the these two datasets and avoiding overlapping of countries between the two, we obtain a second sample of 14.330 observations covering 24 countries (Australia, Belgium, Canada, Chile, Czech Republic, Denmark, Finland, France, Germany, Hungary, Ireland, Italy, Japan, Netherlands, New Zealand, Norway, Poland, Portugal, Russian Federation, Spain, Sweden, Switzerland, United, Kingdom, United, States). This sample contains adult individuals, and is more appropriate to study educational attainment, as well as the distribution of basic competences. Descriptive statistics are also reported in Table 3.

To compare our results with the existing literature based on student test scores, we have also used a fourth dataset, drawn from the Programme for International Student Assessment (PISA), an internationally standardised assessment promoted every three years by OECD and administered to15year-olds in schools. We use the 2003 survey, which includes 41 countries. ${ }^{30}$ The survey measures competences in four areas (reading ability, numeracy, scientific knowledge and problem solving). The questionnaire contains detailed information on the family background of students, on their motivations and aspirations, as well as on the contents of their relationship with parents and teachers. Additional questionnaires report information on previous educational career, access and ability to use of ICT (OECD 2004). The main limit of this survey is its cross-section nature of individuals similarly aged, which prevents us to exploit time variations to identify potential effects of institutional differences. ${ }^{31}$ For this reason, we will use this dataset as auxiliary, to explore the role of parental background in secondary school choices.

\subsection{The Outcomes}

We group education outcomes into three main groups: educational attainment; early labour market experience and skill development, and study their correlation with family background, with special focus on how schooling institutions influence the family background effect. We look at the distribution of educational attainment in the sample from different perspectives:

i) the attainment of the average individual, which we capture with the years of education (Table 4);

ii) the bottom tail, which we study by focusing on the probability of being a school dropout ${ }^{32}$ (Table 5);

iii) the upper tail, or the probability of being enrolled in college or having a college degree (Table 6);

\footnotetext{
30 The countries participating in the 2003 survey are Australia, Austria, Belgium, Brazil, Canada, Czech Republic, Denmark, Finland, France, Germany, Greece, Hong Kong (China), Hungary, Iceland, Indonesia, Ireland, Italy, Japan, Korea, Latvia, Liechtenstein, Luxembourg, Macao (China), Mexico, Netherlands, New Zealand, Norway, Poland, Portugal, Russian Federation, Slovakia, Spain, Sweden, Switzerland, Thailand, Tunisia, Turkey, United Kingdom, United States, Uruguay, Serbia and Montenegro.

${ }^{31}$ For this reason many authors prefer the TIMMS surveys (as in Schuetz, Ursprung and Wößmann (2005) or combine PISA survey with other surveys conducted on younger children (as in Waldinger 2006).

${ }^{32}$ Following the OECD, we define school dropouts as individuals aged 20 to 24 who are not in school and have at most ISCED 2 education.
} 
iv) the dispersion of educational attainment in the population, described by the correlation between a measure of dispersion (the coefficient of variation of years of schooling) and the corresponding dispersion of family background (Table 7).

To study how these outcomes interact with family background and schooling institutions, we use the pooled IALS-ISSP dataset, which covers 24 countries.

We look at the labour market outcomes of young adults by using the standard tools of price and quantity and focusing on:

v) employment, or the probability of being employed, unemployed or out of the labour force (Table 8);

vi) earnings, which we study by explicitly taking into account self-selection into paid employment with the usual Heckman procedure (Table 9);

vii) earnings inequality in the working population, which we analyse by considering the correlation between a measure of dispersion (the coefficient of variation of wages) and the corresponding dispersion of family background (Table 10).

We look at labour market outcomes by using the ECHP-ISSP dataset.

Finally, we consider skill development by focusing on:

viii) literacy, measured with the ability to read, process documents and carry out quantitative analysis (Table 11);

ix) literacy inequality, or the coefficient of variation of literacy, which we relate to the dispersion of family background (Table 12);

$x$ ) access to job training, or the probability of having participated to a training event since the year before the interview (Table 13).

We look at these outcomes by using either IALS or the combined ECHP-ISSP dataset.

Before discussing our results, we briefly review our theoretical expectations, using a simple graph to illustrate. In Figure 1 we trace the relationship between the educational attainment of two subsequent generations. In the South-West quadrant we assume that parental education has a given normal distribution. Next, we assume that the relationship between child and parent education is linear (the solid line in the South-East quadrant), and map the distribution of educational attainment of the children from the distribution of parental education. As argued in the model reported in Appendix 1, a change in schooling institutions may affect the relationship between the two distributions. Suppose that an increase in school tracking length increase the effect of parental education on the education of children in a non-linear way, as shown in the dashed line in the South-East quadrant ${ }^{33}$. If this is the case, the effect of parental background is attenuated for low-education families, but reinforced for

33 The solid line corresponds to the function $h_{t+1}=1+0.8 \cdot h_{t}$, while the dashed line is obtained from $h_{t+1}=2.54+0.2 \cdot h_{t}^{1.55}$. Given a normal distribution of $h_{t}$ with $\mu=5, \sigma=1$, these two function generates two normal distributions, with almost identical means, and the latter characterised by lower variance than the former. 
better educated parents. As a consequence, educational attainment falls at both tails, with an ensuing reduction in educational inequality. This is rather consistent with what we shall find in the empirical analysis.

Turning to the other outcomes, it is natural to expect that labour market outcomes are positively correlated with educational attainment. Thus, we expect to find an analogous relationship between parental education and either employment probability and/or earnings. On the contrary, we do not have strong a priori expectations with regard to skill development. We know that "learning begets learning", and that this carries on from formal education to training opportunities (see Bassanini et al. 2006). Actual skills, however, are also the product of work experience, which is not necessarily correlated with educational attainment. While we find reasonable to expect a positive correlation between parental background and individual cognitive skills, we do not have strong expectations on how this relationship is modified (if ever) by changes in the institutional design educational structures.

\subsection{Parental background and the role of confounding factors}

In our framework it is essential to have good measures of parental background. While the ECHP includes measures of parental income (at least for the individuals still leaving with their families, which is more likely in Southern countries), the other datasets have information on parental occupation, which is not cross-country comparable - except in the case of PISA, where occupation is associated with an index of social prestige. Thus we resort to parental education, which is available in all datasets as a 3-outcomes variable. ${ }^{34}$ Two datasets (the ISSP survey in 1999 and PISA 2003) also report information on the (estimated) number of books when the interviewee was 15-years old, while another one (IALS) asks about the number of books currently at home, which cannot be taken as a proxy for parental background at the time of schooling. Using the number of books as an alternative proxy for family background yields similar results, which we do not report to save space.

For each outcome variable, we estimate four specifications ${ }^{35}$, which include respectively:

a) parental background alone and interacted with length of tracking;

b) parental background alone and interacted with the share of students enrolled in vocational tracks;

c) parental background alone, interacted both with length of tracking and with share of students enrolled in vocational tracks;

d) parental background alone and interacted with the product of tracking length and the share of students in vocational tracks.

\footnotetext{
34 We have considered the highest educational attainment in the couple of parents, coding 0 when no parents completed secondary education, 1 when at least one parent has a secondary education degree and 2 when at least one parent has a college degree.

35 All regressions include age and gender.
} 
While in specifications b) and c) the two measures of school tracking identified in the theoretical section are included separately, in the last specification we allow them to interact in their impact on the family background effect.

These four specifications are replicated five times, first without any confounding factor and then by introducing one by one interaction of parental background with schooling variables, which might influence the family background effect independently of school tracking - the share of students in pre-primary schools, the share of private schools, public expenditure in education and the studentteacher ratio. We are forced to introduce these additional controls once at a time, to avoid collinearity problems. Our results are reported in Tables 4-13.

When we study the overall impact of schooling institutions onto the distribution of outcomes, be it years of education, earnings or literacy, we regress our measure of outcome dispersion (the coefficient of variation) on an analogous measure of dispersion of parental background, and interact the latter with schooling institutions. We expect to find a close correspondence in signs between the regressions in levels and those using coefficients of variation. ${ }^{36}$

\section{Empirical Results}

\subsection{Education}

We start with educational attainment, measured as the number of years of education attained by the average individual in the sample (Table 4), using the IALS-ISSP sample. As expected, we find that parental education and the educational attainment of the offspring are positively correlated. This effect is reinforced when tracking length is longer. However, the coefficient associated to the interaction between family background and tracking length is not very precise - significant at the $10 \%$ level of confidence in most cases - and becomes statistically not significant when we include the interaction of parental background with public expenditure in education as a share of GDP. The share of students enrolled in vocational schools, which in our model would affect the FBE in the presence of non-linear peer effects, is never statistically significant. We have also verified, but do not report in the paper,

\footnotetext{
${ }^{36}$ If we test the significance of a relationship like $Y=A \cdot F B^{\gamma(T)}$ where $Y$ is the outcome, $F B$ the measure of family background and $T$ a measure of school design, its corresponding log-version is $y=\alpha+\gamma(T) f b$. If $F B$ is lognormally distributed (which is reasonable especially when $F B$ represents family income), then $f b$ is normally distributed with moments $\left(\mu_{f b}, \sigma_{f b}^{2}\right)$, and $y$ is also normally distributed with moments $\left(\alpha+\gamma \mu_{f b}, \gamma^{2} \sigma_{f b}^{2}\right)$. Then the coefficient of variation of $f b$ is $C V_{f b}=\frac{\sigma_{f b}}{\mu_{f b}}$, and the corresponding measure of $y \quad$ is $C V_{y}=\frac{\gamma(s) \sigma_{f b}}{\alpha+\gamma(s) \mu_{f b}}=\frac{1}{1+\frac{\alpha}{\gamma(s) \mu_{f b}}} \cdot \frac{\sigma_{f b}}{\mu_{f b}}=\Gamma(s) C V_{f b}$. Therefore by construction $\operatorname{sign}\left(\gamma^{\prime}\right)=\operatorname{sign}\left(\Gamma^{\prime}\right)$.
} 
whether the effect of the share of students in the vocational track varies with the parental background of pupils, as suggested by the model in the Appendix 1, but have found no evidence for that. ${ }^{37}$

Turning to the analysis of the two tails of the distribution of educational attainment, we consider the probability that the individuals in the sample have not attained upper secondary education. Our results in Table $5^{38}$ show rather clearly that earlier tracking reinforces the negative effects of a "good" parental background on the probability of dropping out. Our results are less controversial when we focus on the upper tail of the distribution of educational achievement. In table 6 we focus on the probability of being enrolled at or having completed university. Here, the evidence is that individuals from a better family background are more likely to be enrolled at or to have completed college. This effect is reinforced when the tracking length is longer or the share of students enrolled in vocational schools is lower. Based on the model presented in the Appendix 1, our results are consistent with the fact that peer effects matter relatively more in tracked than in comprehensive schools. Contrary to the evidence on educational attainment, they also point to the presence of non-linear peer effects. One alternative explanation is associated to the organization of tracking in most countries, which usually prevents the possibility of university enrolment. While these effects are robust to the introduction of confounding schooling variables, we are puzzled by the negative sign attracted by the interaction of parental background and the share of private schooling.

Finally, we consider the dispersion of educational attainment in Table 7. Here, we do not find statistically significant effects of institutional design, except for the pupil-teacher ratio. If we consider this as a negative proxy of school resources, we notice that - other things constant - the inequality induced by parental background tend to be stronger in countries where the pupil-teacher ratio is higher.

Overall, these results are consistent with our theoretical model: the length of tracking generally reinforces the family background effect, while the share of students in vocational works goes in the opposite direction.

\subsection{Labour market outcomes}

We now move to study how school design and family background interact in the determination of employment and earnings. In Table 8 we report the estimated coefficients of the probability of being "employed" relative to the probability of being "out of the labour market". Since students are classified in the last group, it is not surprising that parental background is negatively associated with this probability. This effect is reinforced both by tracking length, and by a higher share of students enrolled

\footnotetext{
37 This may be due to the fact that parental background has only three entries, which allow for just two dummies, making it difficult to capture a weak nonlinearity.

38 One may object that this measure fails to account for the education completed in the apprenticeship systems typical of countries with early tracking, but unfortunately this inforamtion is not available in our data-set.
} 
in vocational schools. One the one hand, good parental background makes college attendance more likely and employment condition less likely. On the other hand, a larger share of students in the vocational track should reduce parental background effects to be consistent with our results on college. However, this is not the case. One explanation is that vocational tracks provide skills that can be spent rather easily in the labour market, thus favouring the employability of individuals from relatively poor family background, who have less access to favourable social networks.

Table 9 presents the results for earnings. Since assignment to employment is non-random, we estimate a simultaneous Heckman model and identify participation with variables which capture family composition. Consistently with the finding on years of education in Table 4, we find that earnings are positively associated with parental education, and that this relationship is reinforced both by the extent of tracking and by the share of students enrolled in vocational schools.

Table 10 looks at earnings inequality, again using the combined ECHP-ISSP sample. Here, we find that the dispersion of family background is positively correlated with the dispersion of children earnings only in few specifications. On the other hand, it's the interaction of this dispersion with tracking length is frequently positive and statistically significant.

\subsection{Life-long skills}

Lastly, we turn to skill formation. Table 11 looks at the correlation of parental background with reading skills, using the IALS sample. It turns out that parental education is positively correlated with these skills. Interestingly, this effect is weaker in settings with longer tracking length or with a large share of students enrolled in vocational schools. Therefore, earlier tracking seems to reduce the impact of family background on the development of cognitive skills. This finding does not square well with previous findings in this literature. Schuetz, Ursprung and Wößmann (2005), for instance, find that earlier tracking increases the impact of parental background on the standardized cognitive test scores taken by TIMMS at age 13. Waldinger (2006) on the other hand, finds no significant effect of schooling institutions on the FBE when examining the standardized tests taken at 15 by PISA.

While the tests taken by TIMMS, PISA and IALS are not strictly comparable, they all refer to cognitive skills. The IALS data we use refer to individuals aged 18 or older, who may have completed high school or dropped out, and who have spent some time in the labour market. One way to reconcile these results is to argue that the time spent in the labour market undoes the negative impact of tracking on the family background effect. Another possible explanation is that our window of observation is more suitable to fully capture the effects of school tracking than earlier windows at 13 or 15, when the real effects on individual human capital have only started to unwind. 
The positive contribution of tracking to reducing the impact of parental background on literacy extends also to the dispersion of literacy (Table 12). In addition, the parental background effect is also attenuated in countries with higher expenditure in education, while pre-primary enrolment works in the opposite direction.

Finally, we consider how tracking affects the relationship between parental background and training (Table 13), using either the data from ECHP or from IALS. If the "learning begets learning" hypothesis holds, we should find results that are consistent with educational attainment. We find that parental background has a positive and statistically significant effect on training only in the IALS sample. The interaction between parental background and tracking is negative, which suggests that the impact of family background is weaker in countries with earlier tracking.

\subsection{Summing up}

Table 14 summarizes our findings. Inspection of the second column in the Table suggest that school tracking interacts in a number of way with parental background in the determination of educational and labour market outcomes. Whenever tracking reinforces the family background effect, it contributes to reducing intergenerational mobility in educational attainment and to foster inequality. Reinforcement is the pattern for educational attainment and early labour market outcomes, but the opposite holds for literacy and training.

How can we reconcile these findings? Suppose that the earnings of young adults combine the effects of formal education, education on the job (training) and skill development both at school and in the job (literacy). Suppose also that non-cognitive skills matter in the wage generating function. Then the reinforcing effects of tracking on the FBE on earnings is the combination of the reinforcing effects on formal education and the weakening effects of learning on the job and in the market. Our results suggest that the net outcome of this combination is negative, and that the effects on educational attainment matter the most. By producing specialized skills, early tracking could reduce the influence of privilege in the assignment to training, because of the complementarity between vocational schooling and apprenticeships, and on the development of real skills, such are reading. By reducing the opportunities to access college, however, tracking may exacerbate the influence of privilege on the highest level of educational attainment, and on high paying college jobs.

As already mentioned, the findings on literacy apparently contradict the findings by Schuetz, Ursprung and Wößmann (2005), who argue that early tracking reinforces the effect of parental background on standardized reading and maths skills, thereby exacerbating inequality of opportunity. To further investigate, we have replicated the estimates of the determinants of literacy in the PISA 2003 sample to check whether our different results can be attributed either to a different sample or to 
different tracking indicators or finally to other factors (see table 15). ${ }^{39}$ Using our indicators, we confirm that tracking length reinforces the impact of parental education on the literacy competences for 15year-old students, and that this effect survives even when including additional indicators of school design. We conclude from this that the relationship between school tracking and parental background is not independent from the window of observation. Tracking possibly exacerbates the FBE early on, at the age of selection into tracks or immediately after. When we take a longer perspective, however, and ask whether these reinforcing effects persist in tests taken later on, we find that they don't.

\section{Policy implications}

We now discuss the policy implications of our empirical results. As we remarked at the forefront, given the data at hand we cannot assess the efficiency implications of school tracking, because we cannot disentangle in the empirical analysis these effects from confounding factors. Therefore, we focus on the equity dimension. This is an important dimension of the issue, and an apparently uncontroversial one: whenever tracking allocates pupils to schools with different value based on parental privilege, inequality of outcomes increases. Policies which de-track schools have the merit of reducing the inequality of opportunity.

The previous literature examines how school tracking interacts with family background in determining school outcomes early on, either at 13 or at 15 , and focuses on the results of standardized cognitive tests as the measure of school outcome. As reviewed above, some authors- notably Ammermüller (2005), Schuetz, Ursprung and Wößmann (2005), Hanushek and Wößmann (2006), and the reference therein - confirm the intuition that earlier tracking reinforces the role of parental background. Other authors - see Waldinger (2006) - question whether these effects are real and claim the absence of significant effects of tracking of the inequality of opportunity.

We have motivated this paper by asking whether the potential role of tracking in reducing equality of opportunity by reinforcing family background effects persists beyond the early tests taken at 13 and 15 and affect the educational attainment, skill development and early labour market history of young adults. Suppose that it does, perhaps because learning is persistent over time, or because the negative effects of tracking do not concentrate at the time of track selection, but unravel during secondary school and at the critical time of college choice. Then the damaging effects of early tracking on inequality are even more relevant for policy, because they spread from the classrooms of early secondary school to early working life.

\footnotetext{
${ }^{39}$ In order to increase comparability, our dependent variable is the (log of) average test score over four areas of PISA testing (mathematical literacy, reading literacy, scientific literacy, problem solving). Parental background is defined in a consistent way in order to maintain comparability with IALS.
} 
Suppose instead that the reinforcing effects of tracking weaken or even disappear at age 18 or later, during college or in the early stage of labour market experience. Then policy concern on the inequality implications of early tracking are likely to be over-emphasized, and policy measures such as de-tracking are less justified.

On balance, our results do not provide a clear-cut answer to this important policy question. Consider for instance the literacy scores in the standardized tests taken by young adults, aged between 18 and 35. Presumably these scores reflect not only formal schooling until the mid twenties, but also training and early labour market experience. For this sample of individuals we find that early school tracking reduces the impact of family background on the level and the coefficient of variation of literacy. Clearly, one must allow for the fact that the design of the tests carried out by TIMMS, PISA and IALS is not the same. Notice, however, that all these surveys focus on cognitive abilities.

The weakening effect of early tracking on the family background effect could depend on training, as we find that early tracking also reduces the impact of family background on the provision of training. One explanation is that the type of skills provided by vocational schools increases the trainability of workers, thereby reducing alternative selection mechanisms, such as those based on parental background and the associated informal networks.

Can we conclude that early tracking is beneficial in reducing inequality of opportunity? Not at all if we look at educational attainment and early labour market history. On balance, our results suggest that early tracking reinforces the family background effects on the years of completed education, on the probability of dropping out and of enrolling or graduating in college. Therefore, in countries with less pronounced tracking, the difference in the dropout rate and college enrolment or completion between the children of poorly and better educated parents is smaller than in countries with stronger tracking.

Perhaps more importantly, we also find that early tracking also reinforces the impact of parental background on earnings. How do we reconcile this latter finding with the findings on literacy and training? In our empirical estimates, we have associated log earnings to individual controls, country by cohort dummies, parental background and the interaction of parental background with school tracking and other confounding factors. We can think of this specification as a reduced form: suppose that log earnings depend on educational attainment, training, and accumulated skills, measured by the literacy test scores. In our empirical model, each explanatory variable depends on parental background and its interactions with tracking and other confounding factors. If we replace the explanatory variables with their empirical determinants, we obtain our empirical specification of log earnings, which depend on individual effects, country by cohort dummies, parental background and its interactions with tracking and other confounding effects. Then, the impact of tracking on the family background effect on earnings is the combination of the impact on the effect on educational attainment, literacy and training. Our empirical results suggest that this impact reinforces the FBE on education, but reduces it with 
respect to training and literacy, and that the former effect prevails on the latter two. Differently put, the channel working its way on educational attainment matters more for wages than the channel operating through literacy and training.

If we take labour market earnings as the key indicator of inequality of opportunity, the natural conclusion we draw from our analysis is that we should concentrate our attention on the effect of tracking on educational attainment rather than on standardized test scores. This is far from surprising, since we are considering labour market outcomes in the early stages of an individual career - for wages we are taking individuals aged 20 to 24 in the ECHP, and we know that the impact of education on wages declines as individual ages and the signalling effect of schooling loses importance in favour of labour market experience.

Due to data limitations, our empirical evidence does not cover all the relevant aspects of tracking from an equity perspective. For instance, an evaluation in terms of equity of tracking requires that we also investigate the assignment rule used in a tracked system. For the sake of simplicity, our theoretical discussion was carried out on the assumption of perfect observability of individual talent, and the assignment was based on pure ability. This may be too simple, and other important factors could be at play. We can provide some evidence on this by looking at the allocation of students to tracks as they can be inferred from their distribution in the PISA 2003 survey. In most countries where vocational schools are available, they sort students into qualitatively different tracks, and provide a lower quality education. Table 16 reports the median differences between students in general and vocational tracks, at the same age and in the same grade. On average, $40 \%$ of the students in these countries are enrolled in vocational tracks, and they possess a lower level of literacy (the difference being highest in reading and lowest in problem solving). Given the possibility of student sorting, this could be either the reflection of individual characteristics, peer effects or the outcome of the different educational curricula provided in vocational schools, or a combination of all these factors. We explore the nature of the sorting process taking place in countries with tracking in Table 17, which reports the estimates of a probit model, where the dependent variable is attending a vocational school (columns 1 to 4). To provide a benchmark for comparison, especially in the case of non-tracked countries, we have also investigated the probability of attending a private school (columns 5 to 8). We are interested in understanding whether student sorting is based on ability, parental education or parental income, and whether this is affected by institutional differences in the extent of tracking. As a measure of ability we cannot use test scores - they could be endogenous if different types of schools provide different types of education - and we resort to information on whether during the previous year a student has obtained scores that are at or above/below the pass mark in mathematics. ${ }^{40}$ In order to better capture the role of

40 We have also considered alternative proxies for abilities, based on the number of repetitions during the previous schooling career (see Goux and Maurin 2006), but not all the countries resort to grade repetition to cope with low ability 
cultural resources, we also include a variable measuring the number of books available at home. For parental income, we use two alternative measures: an index of occupational prestige ${ }^{41}$, and an index of possession of durables and cultural resources (both variables being positively correlated with unreported family income). The results in Table 17 show that students enrolled in vocational schools are more likely to be older boys, with low performance at school, coming from less educated parents (either in terms of educational attainment or in terms of books available at home), which are typically also poorer (columns 3 and 4). Thus sorting into vocational schools is based on both ability and family background. When we interact these variables with institutional design, we notice that more tracked systems attenuate the impact of ability, while reinforcing the role of cultural resources of the family of origin (columns 2 and 4). As a term of comparison, let us have a look to the sorting process between public and private schools. Students enrolled in private schools are also sorted by ability, by parental educational attainment and, more effectively, by parental income (meaning that abler students with more educated and richer parents are more likely to be enrolled in private schools). In this case institutional differences related to tracking are statistically insignificant, except in the case of ability, since in countries where tracking is longer and/or more widespread in the student population (and/or any combination between these two cases) enrolment in private vocational schools is more likely.

Finally, in search of country specific variations, we have re-estimated the same model by allowing for a country-specific impact of ability and parental background. The country specific coefficients are reported in Figure 2. While there is significant variation in terms of the impact of ability, we are unable to find a clear trade-off between sorting on ability and sorting on family background. Based on sorting by ability (as it seems to occur for formerly planned economies Yugoslavia, Hungary, Czech Republic and Slovakia), students should observe a reduction in the impact of the parental education, but the two effects seem to reinforce each other. Thus we do not find a clear pattern in student sorting among alternative tracks, even if students allocation based on observables is more transparent (and potentially more equitable, especially when based on ability and not on parental background) in some countries than in others.

A final element that needs to be taken into account when discussing the costs and benefits of tracking is the imperfect observability of tracking. We have already mentioned that early tracking is exposed to the risk of misallocation, since either student ability is hard to measure or their willingness

students, and therefore this measure was not available for all countries. The current information on ability based on marks is available only for Australia, Austria, Czech Republic, Germany, Greece, Hungary, Iceland, Indonesia, Ireland, Italy, Latvia, Mexico, Netherlands, Poland, Portugal, Slovakia, Thailand, United States, Uruguay, Serbia and Montenegro (which therefore are the countries included in table 17).

41 “The PISA international socio-economic index of occupational status (ISEI) was derived from students' responses on parental occupation. The index captured the attributes of occupations that convert parents' education into income. The index was derived by the optimal scaling of occupation groups to maximise the indirect effect of education on income through occupation and to minimise the direct effect of education on income, net of occupation (both effects being net of age). For more information on the methodology, see Ganzeboom et al. (1992). The highest international socio-economic index of occupational status(HISEI) corresponds to the highest ISEI of either the father or the mother.” (OECD 2004, p.307). 
to proceed in the educational ladder is not well formed ${ }^{42}$. On the contrary, later tracking may represent a waste of resources, since it retains into general education individuals who have already made their mind in a work-based career. Especially in the past decade some countries have opted for postponing the tracking to a later age and/or to a tertiary level. This appears more equitable, since students assignment is based on more reliable information, but it may exacerbate other problems, like excessive aspirations (captured by over-education).

We are sympathetic to this option, since we believe that the costs of early tracking overwhelm the benefits. Our ideal schooling system should consider a block of compulsory education (say ten years), which has to be identical for all students, independent of their future aspirations (which often reflect parental aspirations). In order to minimise the future risk of over-education, compulsory education has to include some non-cognitive practically oriented training. Compulsory education should be then followed by a block of tracked secondary schools (lasting from 2 to 4 years), each giving access to some tertiary education. Nordic countries (Norway, Denmark, Finland and Sweden) are organised along similar lines. In this way we achieve three results: people aspiring to progress in education are not prevented in proceeding further; we reduce the risk of keeping together in the same class students with very different levels of aspirations (which is one of the main criticism to comprehensive systems); and finally one can take advantage of peer effects.

\footnotetext{
${ }^{42}$ See Brunello, Giannini and Ariga, 2004, for a model of tracking with poorly measured ability.
} 


\section{Appendix 1 - School tracking and parental background: two illustrative models.}

\section{A.1 Tracking in the presence of peer effects}

To illustrate the relationship between tracking and peer effects, consider the following simple model, based on the original work of Benabou (1996) on geographical segregation. Start with $n$ students, indexed by $i=1,2, \ldots, n$, and $m$ schools, indexed by $j=1,2, \ldots, m<n$, with $\gamma=n / m$ being the school size, assumed identical for all schools. Without loss of generality, we rescale the number of students to be equal to the number of schools, so that the school size becomes unitary $(\gamma=1)$. The formation of individual human capital is assumed to depend on parental background $F$, individual ability $A$ and the school peer effect $P$, which is based on the ability composition of the class. ${ }^{43}$

For simplicity we assume that these inputs are imperfect substitutes in the human capital production function

$$
H_{i j}=f\left(F_{i j}, A_{i j}, P_{j}\right)=F_{i j}^{\delta} A_{i j}^{\eta} P_{j}^{\theta}
$$

where $H_{i j}$ is the human capital of student $i$ enrolled in school $j, F_{i j}$ is her family background (be it parental education, parental income, family wealth or any combination of them), $A_{i j}$ is her individual ability and $P_{j}$ is the peer effect in school $j$. In order to allow for different forms of interaction and cooperation among students, we follow Benabou (1996) in assuming that the peer effect can be measured by a CES (constant elasticity of substitution) index

$$
P_{j}=\left[\sum_{i=1}^{\gamma} A_{i j}^{\sigma}\right]^{\frac{1}{\sigma}}
$$

We assume that students belong to one of two ability types, $A_{H}>A_{L}>0$, with $n_{1}$ being the number of "high" types and $\left(n-n_{1}\right)$ the number of "low" types. We also define $\alpha=\frac{n_{1}}{n}$ as the corresponding fraction of high types in the population. We know from Benabou (1996) that when $\sigma<1$ ability types are complements, $L$ is convex in $\alpha$, the number of talented students in the class, and heterogeneity is a source of efficiency loss, since

$$
P_{j}=\left[\alpha A_{H, j}^{\sigma}+(1-\alpha) A_{L, j}^{\sigma}\right]^{\frac{1}{\sigma}} \leq \bar{A}_{j}=\alpha A_{H, j}+(1-\alpha) A_{L, j}
$$

On the contrary, when $\sigma>1, L$ is concave in $\alpha$, heterogeneity is a source of gain, and the integration of students reinforces the peer effect.

Applying these concepts to school design, they imply that pooling students of different ability into a comprehensive educational system is more efficient (in terms of the production of human capital) when ability types are substitutes, whereas tracking systems, which gather students of similar abilities in the same schools, are more efficient when abilities are complements. More formally, if

\footnotetext{
43 Benabou (1996) calls this term the "local interaction" effect, which more generally could include the social composition of the class, and capture role models, social capital, family networking and related phenomena. We restrict our analysis to the pure "peer effect" based on student ability. Since student ability in this model is assumed to be perfectly observable, sorting does not entail the misallocation of students.
} 
students are sorted into classes with homogeneous ability, this is considered as equivalent to a tracked system, where high ability students are selected into the academic track $\mathrm{H}$ and low ability students go to the vocational track L. With tracking, individual human capital formation is given by ${ }^{44}$

$$
H_{i}=F_{i}^{\delta} A_{i}^{\eta+\theta}, i=L, H
$$

The total human capital accumulated in the society will therefore be

$$
H_{\text {stratified }}=\sum_{i=1}^{n} H_{i}=\sum_{i=1}^{n} F_{i}^{\delta} A_{i}^{\eta+\theta}=A_{H}^{\eta+\theta}\left(\sum_{i=1}^{n_{1}} F_{i}^{\delta}\right)+A_{L}^{\eta+\theta}\left(\sum_{i=n_{1}+1}^{n} F_{i}^{\delta}\right)
$$

If instead the system is fully integrated, each school exhibits the same ability composition, and individual human capital formation is given by

$$
H_{i}=F_{i}^{\delta} A_{i}^{\eta}\left[\alpha A_{H}^{\sigma}+(1-\alpha) A_{L}^{\sigma}\right]^{\theta}, i=L, H
$$

while total human capital in the society is

$$
H_{\text {comprehensive }}=\sum_{i=1}^{n} H_{i}=A_{H}^{\eta}\left[\alpha A_{H}^{\sigma}+(1-\alpha) A_{L}^{\sigma}\right]^{\theta}\left(\sum_{i=1}^{n_{1}} F_{i}^{\delta}\right)+A_{L}^{\eta}\left[\alpha A_{H}^{\sigma}+(1-\alpha) A_{L}^{\sigma}\right] \frac{\theta}{\sigma}\left(\sum_{i=n_{1}+1}^{n} F_{i}^{\delta}\right)
$$

The comparison of equations (8) and (10) does not lead to clear-cut conclusions, since the peer effect interacts with individual ability and family background, and the aggregate effect depends on the joint distribution of these two variables. If we abstract from these effects - and set $\delta=\eta=0, \theta=1$ - it is easy to show that $H_{\text {comprehensive }}>H_{\text {track }}$ if and only if $\sigma>1$, and vice versa. Therefore de-tracking schools is efficiency-enhancing if student abilities are substitutes in the generation of the peer effect.

One problem with the current simplified setup is that in most countries both comprehensive and tracked schools coexist, often in sequence, with an initial period of comprehensive (primary and in most cases lower secondary) school, followed by tracked (upper) secondary schools. Defining $\tau$ as the length of tracked education in a country, each student accumulates human capital as follows

$$
\begin{aligned}
H_{i} & =(1-\tau) F_{i}^{\delta} A_{i}^{\eta}\left[\alpha A_{H}^{\sigma}+(1-\alpha) A_{L}^{\sigma}\right]^{\theta} \sigma-\tau F_{i}^{\delta} A_{i}^{\eta+\theta}= \\
& =F_{i}^{\delta} A_{i}^{\eta}\left\{(1-\tau)\left[\alpha A_{H}^{\sigma}+(1-\alpha) A_{L}^{\sigma}\right]^{\theta} \sigma \tau A_{i}^{\theta}\right\}, i=L, H
\end{aligned}
$$

Since we want to assess how education reforms which de-track schools affect human capital inequality, we define the family background effect (FBE) as the contribution of family background to individual educational attainment (namely $F B E=\frac{\partial H_{i}}{\partial F}$ ) and compute

$$
\frac{\partial F B E}{\partial \tau}=\frac{\partial^{2} H_{i}}{\partial F_{i} \partial \tau}=\delta F_{i}^{\delta-1} A_{i}^{\eta}\left\{A_{i}^{\theta}-\left[\alpha A_{H}^{\sigma}+(1-\alpha) A_{L}^{\sigma}\right]^{\frac{\theta}{\sigma}}\right\}, i=L, H
$$

\footnotetext{
${ }^{44}$ Notice that we are implicitly assuming that the distribution of school types will match the distribution of ability types in the society.
} 
which shows that the second order mixed derivative is positive for "high talent" students and negative for "low talent" students. This implies that an increase in the length of school tracking reduces the impact of family background for low ability students but increases it for the high ability group. The effect of longer tracking on the FBE for the average student depends on the relative share of each ability type in the population of students. By extension, given the distribution of family background, this differential effect should produce a reduction in inequality in the lower tail of the human capital distribution and an increase in dispersion in the upper tail. The overall effect will therefore be indeterminate. Symmetrically, a reform which de-tracks school is likely to reinforce the FBE for low talent students and to reduce it for high talent group.

\section{A.2 Parental background and the allocation to tracks}

The model in the previous sub-section illustrates the efficiency gains or losses of tracking students in different classes and emphasizes the technical relationship between ability types. In that model, however, parental background has no effect on the allocation of students to tracks. In policy discussions, this is an important aspect, which lies at the very root of equity concerns. The main issue here is whether individuals are allocated to the lower ability track not because of actions they control, such as low effort, but because of circumstances outside their own control, such as being born in an affluent household.

In this second model, we assume that the allocation of students to tracks depends on ability. Ability is partly in the genes and partly depends on the household environment where the individual spends her pre-school years. A residual component is purely idiosyncratic, and orthogonal to parental background. By affecting the development of individual talent, parental background can affect the allocation to tracks. Needless to say, there are other channels which link parental background to type of school, such as household resources and social networks. Since these channels have also the implication that family privilege increases the likelihood of allocation to the best track, as does the channel we emphasize, we ignore them here for the sake of simplicity.

Consider a secondary schooling system, which consists of a comprehensive school (C) of duration $(1-\tau)$, and of a stratified school, of duration $\tau$. The stratified school is composed of a vocational $(\mathrm{V})$ and an academic $(\mathrm{G}) \operatorname{track}^{45}$. Households consist of a mother and a daughter. Individual ability $\Theta$ has a component $B$ common to the mother and the daughter, which we broadly identify with family background, and an additional idiosyncratic component $D$, which is independent of family background. The underlying idea is that individual talent depends on the genes and develops during the initial stages of life. This development is favoured by good family characteristics, such as parental education and the presence of books at home ${ }^{46}$. Family background, however, cannot explain entirely individual different in talents, which depend also on idiosyncratic factors.

We model the production of talent $\Theta$ as follows

$$
\Theta=B D^{\lambda}
$$

where $\Theta$ is talent and $\lambda>0$ : good family background can compensate low endowment of idiosyncratic ability, and a large endowment of the latter can compensate, albeit at a different rate, poor family background. If $\lambda$ is small, then the allocation to tracks depends almost exclusively on family

\footnotetext{
45 This model follows rather closely Brunello, Giannini and Ariga, 2004.

46 Carneiro and Heckman, 2003, show that important differences in ability across family types appear at early ages and persist.
} 
background. Both components are lognormally distributed. Let $b$ be the $\log$ of $B$ and $d$ be the $\log$ of D. Then

$$
\begin{gathered}
b \sim N\left(f, \sigma_{f}^{2}\right) \\
d \sim N\left(0, \sigma_{a}^{2}\right) \\
\theta=b+\lambda d \sim \Phi\left(f, \sigma_{\theta}^{2}\right)
\end{gathered}
$$

Enrolment in school depends on $\theta$ : individuals with observed $\log$ ability $\theta$ higher than a predefined threshold $\theta^{*}$ enrol in the $\mathrm{G}$ school, and individuals with a lower $\log$ ability enrol in the $\mathrm{V}$ school. The threshold $\theta^{*}$ is determined by the local or central authority, and defines the number of slots available in each type of school. The probability of enrolling in a $\mathrm{V}$ school is

$$
\Phi\left(\frac{\theta^{*}}{\sigma_{\theta}^{2}}\right)=\operatorname{Pr} o b\left(\theta<\theta^{*}\right)
$$

which corresponds also to the share of pupils enrolled in that type of school.

Let $H$ be the outcome of schooling. This outcome includes the accumulation of skills and the completion of a curriculum, but extends also to the labour market: a good education is measured not only by the portfolio of competencies learned at school, but also by employability and the quality of work it gives access to ${ }^{47}$. Briefly, we call this outcome human capital. Human capital is produced at school and depends both on individual talent $\Theta$ and on the average ability of the class (peer effect) ${ }^{48}$. Schools are endowed with the same resources and employ teachers with equal teaching talent. When schools are fully comprehensive, individual human capital is

$$
H_{C}=\Theta[\exp \beta E(\theta)]
$$

where $E(\theta)$ is the peer effect and $\beta>0$ is the contribution of peer effect to human capital. In logs, this is also

$$
h_{C}=\theta+\beta E(\theta)
$$

where we use small letters for logs.

With tracking, human capital produced in the G school is

$$
H_{G}=\Theta\left[\exp \beta_{H} E\left(\theta \mid \theta \geq \theta^{*}\right)\right]
$$

and in the V school is

$$
H_{V}=\Theta\left[\exp \beta_{L} E\left(\theta \mid \theta<\theta^{*}\right)\right]
$$

\footnotetext{
${ }^{47}$ Card and Krueger, 1992, emphasize labor market outcomes as the natural measure of the returns to schooling.

48 The literature on peer effects is too large to review here. See Nechyba, 2005, for a theoretical review and Hoxby and Weingarth, 2005, for an overview of the empirical research.
} 
When students are allocated to different types of schools and classes, there are three potential effects at play. First, the average talent of the class is either higher or lower than the unconditional mean, depending on the track. In the presence of peer effects, average talent matters for individual performance at school. Second, peer effects can be non-linear. In this case the benefit attained by talented students from being allocated to a good class differs from the loss born by talented students who are allocated to a not so good class. Given the balance of the empirical evidence, we are far from religious in arguing in favour of non-linearities. The latter, however, cannot be excluded in principle. If peer effects matter more in tracked schools, and are also non-linear, then we have $\beta_{H} \neq \beta_{L}>\beta$. If instead peer effects are linear and matter more when types are mixed rather than separated, then $\beta_{H}=\beta_{L}<\beta$.

Suppose that individuals spend time $(1-\tau)$ in the comprehensive school, and the rest of time $\tau$ in a stratified school. The expected log human capital at the end of school for the individuals who go to the $G$ track is

$$
E h_{G}=(1-\tau) \beta f+\left[1+\tau \beta_{H}\right] E\left(\theta \mid \theta \geq \theta^{*}\right)
$$

and for the V track

$$
E h_{V}=(1-\tau) \beta f+\left[1+\tau \beta_{L}\right] E\left(\theta \mid \theta<\theta^{*}\right)
$$

Using the algebra of truncated normal standard distributions, we have

$$
\begin{gathered}
E\left(\theta \mid \theta \geq \theta^{*}\right)=f+\sigma_{\theta} \frac{\phi\left(\frac{\theta^{*}}{\sigma_{\theta}}\right)}{1-\Phi\left(\frac{\theta^{*}}{\sigma_{\theta}}\right)} \\
E\left(\theta \mid \theta<\theta^{*}\right)=f-\sigma_{\theta} \frac{\phi\left(\frac{\theta^{*}}{\sigma_{\theta}}\right)}{\Phi\left(\frac{\theta^{*}}{\sigma_{\theta}}\right)}
\end{gathered}
$$

Notice that the $G$ student stands to gain from peer effects compared to the $\mathrm{C}$ student; on the other hand, the $\mathrm{V}$ student loses, because of the poorer peer group. So, the peer group effect is negative for the $\mathrm{V}$ student, who could partially be compensated if $\beta_{L}>\beta$. Average log human capital is the weighted average of expected human capital in the two tracks. Therefore

$$
E h=(1-\Phi) E h_{G}+\Phi E h_{V}
$$

and

$$
E h=(1-\tau) \beta f+f\left[1+\tau \beta_{H}-\tau \Phi\left(\beta_{H}-\beta_{L}\right)\right]+\tau\left(\beta_{H}-\beta_{L}\right) \sigma_{\theta} \phi
$$

Average log human capital depends on the tracking length $\tau$, on the percentage $\Phi$ of workers enrolled in the $\mathrm{V}$ track, and on average family background $f$. Define FBE as the effect of an increase in average family background on average human capital. This is given by

$$
\frac{\partial E h}{\partial f}=F B E=1+(1-\tau) \beta+\beta_{H} \tau-\tau\left[\left(\beta_{H}-\beta_{L}\right) \Phi\right]
$$


By contributing to the development of individual talent, a shift in the mean of the distribution of $\log$ family background affects average log human capital. The size and direction of this effect depends on the relative importance of peer effects in each track. If $\beta_{H}=\beta_{L}$, then $\frac{\partial E h}{\partial f}>0$.

Notice that a shift in average family background is different from a shift in individual family background: an individual who is assigned to a better background is more likely to be allocated to the $G$ track, and to end up with higher human capital. An increase in average parental background shifts instead the entire distribution of talent. Notice also that we are keeping the threshold $\theta^{*}$ as given. Suppose instead that a shift in the mean of the distribution of parental background, due for instance to an increase in average income per head, leads to political pressure for more school slots in $\mathrm{G}$ schools ${ }^{49}$. In this case $\frac{\partial \theta^{*}}{\partial f}<0$ and

$$
\frac{\partial E h}{\partial f}=F B E=1+(1-\tau) \beta+\beta_{H} \tau-\tau\left[\left(\beta_{H}-\beta_{L}\right) \Phi\right]-\tau f\left(\beta_{H}-\beta_{L}\right) \frac{\phi}{\sigma_{\theta}} \frac{\partial \theta^{*}}{\partial f}-\tau\left(\beta_{H}-\beta_{L}\right) \phi \frac{\theta^{*}}{\sigma_{\theta}} \frac{\partial \theta^{*}}{\partial f}
$$

The question we ask in the paper is whether the relationship between family background and human capital varies with school design. First consider an increase in the length of tracking time, and keep the threshold $\theta^{*}$ as given. Then we have

$$
\frac{\partial F B E}{\partial \tau}=\beta_{H}-\beta-\left(\beta_{H}-\beta_{L}\right) \Phi
$$

A higher tracking time increases the effect of family background on human capital if $\beta_{H}>\beta$, that is, if separating types is more effective for teaching than mixing types. When peer effects are non-linear and $\beta_{H}>\beta_{L}$, the increase in human capital is reduced by a higher share of vocational schools, because these schools are less effective than academic schools in the production of human capital.

Next, we investigate the effect of an increase in the threshold $\theta^{*}$, which corresponds to an increase in the share of vocational schools $\Phi$. We have

$$
\frac{\partial F B E}{\partial \Phi}=\frac{\partial F B E}{\partial \theta^{*}} \frac{\partial \theta^{*}}{\partial \Phi}=-\tau\left(\beta_{H}-\beta_{L}\right)
$$

which is negative if $\beta_{H}>\beta_{L}$. In this case, a higher share of vocational schools reduces the impact of family background on human capital. This is because, when the percentage of students ending up in the vocational track is relatively high, there are relatively fewer slots in the more prestigious academic track, and family background is less effective in guaranteeing a place in such track. Put differently, a higher share of slots in vocational tracks implies that even children from good family background end up studying where the impact of the peer effect is lower $\left(\beta_{L}<\beta_{H}\right)$.

So far, we have considered the impact of a change in school design on average human capital. It is instructive, however, to ask how changes in school design affect the human capital of different groups of students. To do so, consider a situation where both $\tau$ and $\theta^{*}$ are given. In this case, individuals would distribute in the $\mathrm{V}$ and $\mathrm{G}$ schools according to the mechanism outlined above. We ask: what happens if the government decides to increase the slots available to vocational schools,

${ }^{49}$ See the discussion in Ariga, Brunello, Iwahashi and Rocco, 2005. 
relative to $G$ schools? In our setup, this is obtained by increasing $\theta^{*}$. There are three groups of individuals: first consider the group who would have enrolled in $G$ before the change in the threshold, and who still enrol there. For these individuals, the expected human capital is affected by the change in $\theta^{*}$ as follows

$$
\frac{\partial E h_{G}}{\partial \theta^{*}}=\left[1+\tau \beta_{H}\right] \frac{\phi\left[\frac{\phi}{1-\Phi}-\frac{\theta}{\sigma}\right]}{(1-\Phi)}>0
$$

The second group is the one which would have enrolled in $\mathrm{V}$ before the change, and still does. For this group

$$
\frac{\partial E h_{V}}{\partial \theta^{*}}=\left[1+\tau \beta_{L}\right] \frac{\phi\left[\frac{\phi}{\Phi}+\frac{\theta}{\sigma}\right]}{\Phi}>0
$$

For both groups, the increase in the threshold increases expected human capital. Consider finally the group of individuals who would have gone to $\mathrm{G}$ before the change and ends up in $\mathrm{V}$ after the change. Let $\theta^{*}$ be the standard before the change and $\theta^{* *}$ the standard after the change. The variation in expected human capital is

$$
E h_{V}-E h_{G}=\tau\left(\beta_{L}-\beta_{H}\right) f-\left[1+\tau \beta_{H}\right] \sigma_{\theta} \frac{\phi\left(\frac{\theta^{*}}{\sigma_{\theta}}\right)}{1-\Phi\left(\frac{\theta^{*}}{\sigma_{\theta}}\right)}-\left[1+\tau \beta_{L}\right] \sigma_{\theta} \frac{\phi\left(\frac{\theta^{* *}}{\sigma_{\theta}}\right)}{1-\Phi\left(\frac{\theta^{* *}}{\sigma_{\theta}}\right)}
$$

A sufficient condition for (34) to be negative is $\beta_{H}>\beta_{L}$. In this case, the intermediate group stands to lose from an increase in the threshold. This is the classical "ends against the middle" result. One implication of this asymmetry is that an increase in $\theta^{*}$ reduces the $F B E$ for the less privileged below to the average $F B E$ effect.

We also ask how an increase in tracking time affects students. A longer tracking time affect the expected human capital of students in the $\mathrm{G}$ and $\mathrm{V}$ tracks as follows:

$$
\begin{gathered}
\frac{\partial E h_{G}}{\partial \tau}=\left(\beta_{H}-\beta\right) f+\beta_{H} \frac{\sigma_{\theta} \phi}{(1-\Phi)}>0 \\
\frac{\partial E h_{V}}{\partial \tau}=\left(\beta_{L}-\beta\right) f-\beta_{L} \frac{\sigma_{\theta} \phi}{\Phi}
\end{gathered}
$$

While the former effect is positive if $\beta_{H} \geq \beta$, the latter effect is negative if $\beta_{L} \leq \beta$, as individuals in the $\mathrm{V}$ track need to spend more time with peers having lower ability. It is also true that

$$
\frac{\partial E h_{G}}{\partial \tau}-\frac{\partial E h_{V}}{\partial \tau}>0
$$

when $\beta_{H} \geq \beta_{L}$. Since individuals in the $G$ track have higher family background, an increase in the tracking time also raises the positive impact of family background on expected human capital, consistently with (30). 
References

Ammermüller, A. 2005. Educational Opportunities and the Role of Institutions, ZEW Discussion Paper, No. 05-44.

Ammermüller, A. and J.S.Pischke. 2006. Peer effects in European primary schools: Evidence from PIRLS. NBER working paper n.12180.

Ariga, K., G.Brunello, M.Giannini and R.Iwahashi. 2006. Why Is the Timing of School Tracking So Heterogeneous? IZA discussion paper n.1854

Arum, R., A.Gamoran and Y.Shavit. 2004. Inclusion and Diversion in Higher Education: Expansion, Differentiation, and Market Structure in Fifteen Countries. mimeo

Bassanini, A., A.Booth, G.Brunello, M.De Paola and E.Leuven. 2006. Workplace training in Europe. forthcoming in: Brunello,G., P.Garibaldi and E.Wasmer (eds.), Education and Training in Europe, Oxford University Press, 2006 (also IZA Discussion Paper n.1640)

Bauer, P. and R.Riphahn. 2006. Timing of school tracking as a determinant of intergenerational transmission of education. Economics Letters 91(1): 90-97.

Benabou, R. 1996. Equity and efficiency in human capital investment: the local connection. Review of Economic Studies, 63: 237-264.

Bertola, G. and D.Checchi. 2004. Sorting and Private Education in Italy. in D.Checchi and C.Lucifora (eds), Education, Training and Labour Market Outcomes. Palgrave-McMillan 2004

Betts, J. and J.Shkolnik. 2000. The effects of ability grouping on student math achievement and resource allocation in secondary schools, Economics of Education Review 19(1): 1-15.

Billger, S. 2006. Reconstructing School Segregation: On the Efficacy and Equity of Single-Sex Schooling. IZA Discussion paper n.2037.

Black, S., P.Devereux and K.Silvanes. 2005. Why the Apple Doesn't Fall Far: Understanding Intergenerational Transmission of Human Capital. American Economic Review 95(1): 437-449.

Braun, G., J.Micklewright, S.Schnepf and R.Waldmann. 2005. Cross-National Surveys of Learning Achievement: How Robust are the Findings? IZA Discussion Paper n.1652.

Breen, R., R.Luijkx, W.Müller and R.Pollak. 2005. Non persistent inequality in educational attainment: evidence from eight European Countries. mimeo

Brunello, G., K,Ariga and M.Giannini. 2006. The Optimal Timing of School Tracking, forthcoming in P. Peterson and L.Wößmann, (eds), Schools and the Equal Opportunity Problem, MIT Press, Cambridge MA. (also IZA Discussion Paper 955)

Cappellari, L. 2004. High school types, academic performance and early labour market outcomes. IZA Discussion Paper 1048.

Card, D. and A.Krueger 1992. Does school quality matter? Returns to education and the characteristics of public schools in the United States. Journal of Political Economy: 1-39.

Card, D. and A.Krueger. 1996a. School resources and student outcomes: an overview of the literature and new evidence from North and South Carolina. Journal of Economic Perspectives 10(4): 31-50.

Card, D. and A.Krueger 1996b. Labor Market Effects of School Quality: Theory and Evidence, in Gary Burtless, (ed.) Does Money Matter? The Link Between Schools, Student Achievement and Adult Success. Washington, DC: The Brookings Institution, 1996.

Carneiro, P. and J.Heckman 2003. Human capital policy. NBER wp 9495

Checchi, D. and L.Flabbi. 2005. Intergenerational mobility and schooling decisions in Italy and Germany. mimeo

Chevalier, A., K.Denny and D.McMahon. 2005. A multicountry study of intergenerational education mobility. mimeo.

d'Hombres, B. and G.Brunello. 2005. Does Obesity Hurt Your Wages More in Dublin than in Madrid? Evidence from ECHP. IZA Discussion Paper n.1704

Dee, T. and B.Jacob. 2006. Do high school exit exams influence educational attainment or labor market performance? NBER wp. 12199

Di Pietro, G. and A.Cutillo. 2006. Does attending a catholic school make a difference ? Evidence from Italy. Bulletin of Economic Research 58(3): 193-234 
Ding, W. and S.Lehrer. 2006. Do peers affect student achievement in China's secondary school ? NBER wp.12305

Duru-Bellat, M. and B.Suchaut. 2005. Organisation and context, efficiency and equity of education systems: what PISA tells us ?. mimeo

Dustmann, C. 2004. "Parental background, secondary school track choice, and wages", Oxford Economic Papers, 56: 209-230.

Entorf, H. and M.Lauk. 2006. Peer Effects, Social Multipliers and Migrants at School: An International Comparison. IZA discussion paper n.2182

Fertig, M. 2004a. What can we learn from international student performance studies? RWI Discussion paper n.23

Fertig, M. 2004b. Shot Across the Bow, Stigma or Selection? The Effect of Repeating a Class on Educational Attainment. IZA discussion paper n.1266.

Fertig, M. and J.Kluve. 2005. The Effect of Age at School Entry on Educational Attainment in Germany. IZA Discussion Paper n. 1507.

Figlio, D. and M.Page. 2002. School Choice and the Distributional Effects of Ability Tracking: Does Separation Increase Inequality? Journal of Urban Economics 51 (3): 497-514.

Galindo-Rueda, F. and A.Vignoles. 2004. The Heterogeneous Effect of Selection in Secondary Schools: Understanding the changing role of ability. CESIfo conference on Schooling and Human Capital Formation in the Global Economy (Munich September 2004).

Gangl, M., W.Müller, D.Raffe. 2003. Conclusions: explaining cross national differences in school to work transitions, in W.Müller and M.Gangl (eds). 2003. Transition from education to work in EuropeThe integration of the youth into the EU labour market. Oxford University Press.

Ganzeboom, H.B.G., P.M. De Graaf and D.J. Treiman (1992), "A standard international socioeconomic index of occupational status", Social Science Research, Vol. 21, Issue 1, Elsevier Ltd., pp. $1-56$.

Gorard, S. and E.Smith. 2004. An international comparison of equity in educational systems. Comparative Education 40(1): 15-28.

Goux, D. and E.Maurin 2006. Neighbourhood effects on performance at school. IZA dp.2095

Hanushek, E. 1986. The economics of schooling: production and efficiency in public schools. The Journal of Economic Literature 24: 1141-1177.

Hanushek, E. and L.Wößmann. 2006. Does Educational Tracking Affect Performance and Inequality? Differences-In-Differences Evidence Across Countries. Economic Journal 116: C63-C76.

Jenkins, S., J.Micklewright and S.Schnepf. 2006. Social Segregation in Secondary Schools: How Does England Compare with Other Countries? IZA discussion paper n.1959

Krueger, D. and K.Kumar. 2004. Skill-specific rather than general education: a reason for US-Europe growth differences? Journal of Economic Growth 9: 167-2007.

Leschinsky, A. and K.Mayer (eds). 1990. The comprehensive school experiment revisited: Evidence from Western Europe. Verlang Peter Lang.

Manning, A. and J.S.Pisckhe. 2006. Comprehensive versus Selective Schooling in England in Wales: What Do We Know? IZA Discussion Paper n.2072.

Meghir, C. and M.Palme. 2004. Educational reform, ability and family background. IFS wp.04/10

Minter Hoxby, C. 2000. Peer effect in the classroom: learning from gender and race variation. NBER wp.7867

Minter Hoxby. C. and G.Weingarth. 2005. Taking Race Out of the Equation: School Reassignment and the Structure of Peers Effects. MIT mimeo

Noden, P. 2000. Rediscovering the Impact of Marketisation: dimensions of social segregation in England's secondary schools, 1994-99. British Journal of Sociology of Education 21(3): 371-390.

Oakes, J. 1992. Can Tracking Research Inform Practice? Technical, Normative, and Political

Considerations. Educational Researcher 21(4): 12-21

OECD 2004. Learning for tomorrow's world. Paris

OECD 2005. Education at a glance. Paris 
Oosterbeek, H. and D.Webbink. 2004. Wage effects of an extra year of lower vocational education: Evidence from a simultaneous change of compulsory school leaving age and program length. Scholar Discussion paper n.44-04

Palme, M. and C.Meghir. 2005. Assessing the effects of Schooling on wages using a social experiment. American Economic Review 95(1): 414-424

Pekkarinen, T. 2005. Gender Differences in Educational Attainment: Evidence on the Role of the Tracking Age from a Finnish Quasi-Experiment. IZA discussion paper n. 1897.

Pekkarinen, T., R.Uusitalo and S.Pekkala. 2006. Education Policy and Intergenerational Income Mobility: Evidence from the Finnish Comprehensive School Reform. IZA discussion paper n.2204.

Pischke, J.S and T.von Wachter. 2005. Zero returns to compulsory schooling in Germany: evidence and interpretation. CEPR Discussion paper n. 5105

Roemer, J. 1998. Equality of Opportunity. Cambridge MA: Harvard University Press

Schnepf, S.V. 2002. A Sorting Hat that Fails? The Transition from Primary to Secondary School in Germany, Innocenti Working Paper No. 92, Florence: UNICEF Innocenti Research Center.

Schuetz, G., H.Ursprung and L.Wößmann 2005. Education policy and equality of opportunity. CESIFO wp.1518

Schneeweis, N. R.Winter-Ebmer. 2005. Peer effects in Austrian schools. University of Linz working paper n.0502.

Stiglitz, J. 1974. The demand for education in public and private school system. Journal of Public Economics (3): 349-385.

Taylor, C., J.Fitz and S.Gorard. 2005. Diversity, specialisation and equity in education. Oxford Review of Education 31 (1): 47-69.

Vanderhart, P. 2006. Why Do Some Schools Group by Ability? Some Evidence from the NAEP. American Journal of Economics and Sociology 65(2): 435-462.

Vandenberghe, V. 2005. Achievement Effectiveness and Equity. The role of Tracking, Grade Repetition and Inter-school Segregation. forthcoming in Applied Economics Letters

Vandenberghe, V. and S.Robin. 2004. Evaluating the effectiveness of private education across countries: a comparison of methods. Labour Economics 11(4): 487-506

Waldinger, F. 2006. Does Tracking Affect the Importance of Family Background on Students. Test Scores? mimeo

Wasmer, E., P.Fredriksson, A.Lamo, J.Messina and G.Peri . 2006. The Macroeconomics of Education. forthcoming in: Brunello,G., P.Garibaldi and E.Wasmer (eds.), Education and Training in Europe, Oxford University Press, 2006 


\section{Appendix 2 - Data sources}

Our empirical measure of school stratification is based on a review of the educational systems for the countries included in our datasets. Our main sources are the following:

OECD 1993, Education in OECD countries - A compendium of statistical information - 1988/89-1989/90

OECD 1996, Education at a glance

Eurydice 2002, Key data on education in Europe.

Eurydice 2005, Key data on education in Europe.

In addition several international (for example the UNESCO World Higher Education Database (WHED) http://www.unesco.org/iau/onlinedatabases/index.html) and national websites have been consulted.

Data on school attendance for education level (pre-primary, primary, secondary and tertiary) and type of institution (public or private, vocational and general) were obtained from OECD Education Database 2000 (cdrom - it may also reached online at http://www1.oecd.org/scripts/cde/viewsubj.asp? $\underline{\text { SUBJNAME}=\text { education\&SUBJNAME_E}=\text { Education) }}$

ENROLPRE enrolment in pre-primary (ISCED0) onto primary (ISCED1) ${ }^{50}$

VOCUPPSEC ISC3: vocational on all programmes - upper secondary - see table 1

PRIVUPPSEC Enrolment in private institutions - upper secondary

Finally we have obtained two additional variables measuring the resources available in a specific country/year.

STUTEASEC ISC3 all programme: students to teaching staff (from R.Barro-

J.W.Lee, Schooling quality in a cross-section of countries, 1997 and

OECD Database 2000 (cdrom))

EDEXPGDP expenditure from public sources in education over GDP (from

OECD, Education at a glance, 1996)

We searched for data referred to 1985, 1995 and 2002. When this information was not available for the exact year, but was accessible for neighbouring years we used the latter instead of the former. In addition to the data reported in table 1 , the data used in the analysis are reported below.

\footnotetext{
${ }^{50}$ In the absence of reliable information on the relevant population, this variable proxies the attendance rate for pre-primary education.
} 


\section{Tables and graphs}

\begin{tabular}{|c|c|c|c|c|c|c|c|c|c|}
\hline & $\begin{array}{l}\text { age of first } \\
\text { selection } \\
\text { into tracks } \\
\text { mid 80's }\end{array}$ & $\begin{array}{l}\text { age of first } \\
\text { selection } \\
\text { into tracks } \\
\text { mid 90's }\end{array}$ & $\begin{array}{l}\text { age of first } \\
\text { selection } \\
\text { into tracks } \\
2002\end{array}$ & $\begin{array}{l}\text { fraction of } \\
\text { primary+ } \\
\text { secondary } \\
\text { education in } \\
\text { tracking mid } \\
80 \text { 's } \\
\end{array}$ & $\begin{array}{c}\text { fraction of } \\
\text { primary+ } \\
\text { secondary } \\
\text { education in } \\
\text { tracking mid } \\
90 \text { 's }\end{array}$ & $\begin{array}{c}\text { fraction of } \\
\text { primary+ } \\
\text { secondary } \\
\text { education in } \\
\text { tracking } 2002\end{array}$ & $\begin{array}{l}\text { share of } \\
\text { students in } \\
\text { upper } \\
\text { secondary } \\
\text { vocational } \\
\text { mid 80's }\end{array}$ & $\begin{array}{l}\text { share of } \\
\text { students in } \\
\text { upper } \\
\text { secondary } \\
\text { vocational } \\
\text { mid 90's }\end{array}$ & $\begin{array}{l}\text { share of } \\
\text { students in } \\
\text { upper } \\
\text { secondary } \\
\text { vocational } \\
2002 \\
\end{array}$ \\
\hline Australia & 16 & 16 & 16 & 0.167 & 0.167 & 0.154 & 0.306 & 0.648 & 0.630 \\
\hline Austria & 10 & 10 & 10 & 0.680 & 0.680 & 0.667 & 0.754 & 0.774 & 0.723 \\
\hline Belgium & 12 & 12 & 12 & 0.500 & 0.500 & 0.500 & 0.487 & 0.676 & 0.701 \\
\hline Brazil & . & . & . & . & . & . & . & 0.408 & 0.140 \\
\hline Bulgaria & 14 & 14 & 14 & 0.417 & 0.417 & 0.364 & . & 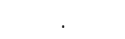 & . \\
\hline Canada & 18 & 18 & 18 & 0.000 & 0.000 & 0.000 & 0.000 & 0.000 & 0.072 \\
\hline Chile & 14 & 13 & 13 & 0.333 & 0.417 & 0.417 & . & 0.420 & 0.396 \\
\hline Czech Republic & 15 & 11 & 11 & 0.250 & 0.615 & 0.615 & 0.540 & 0.844 & 0.802 \\
\hline Denmark & 16 & 16 & 16 & 0.280 & 0.280 & 0.250 & 0.653 & 0.541 & 0.530 \\
\hline Finland & 16 & 16 & 16 & 0.250 & 0.250 & 0.250 & 0.531 & 0.522 & 0.572 \\
\hline France & 16 & 15 & 15 & 0.167 & 0.250 & 0.250 & 0.580 & 0.534 & 0.563 \\
\hline Germany & 10 & 10 & 10 & 0.692 & 0.692 & 0.692 & 0.789 & 0.765 & 0.630 \\
\hline Greece & 14.5 & 14.5 & 15 & 0.280 & 0.280 & 0.250 & 0.328 & 0.293 & 0.400 \\
\hline Hong Kong (China) & . & . & . & & . & . & . & 0.572 & 0.433 \\
\hline Hungary & 10 & 10 & 11 & 0.667 & 0.667 & 0.667 & 0.757 & 0.731 & 0.269 \\
\hline Iceland & . & . & 16 & . & . & 0.286 & . & 0.363 & 0.370 \\
\hline Indonesia & . & . & . & . & . & . & . & 0.390 & 0.355 \\
\hline Ireland & 12 & 12 & 15 & 0.478 & 0.478 & 0.182 & 0.245 & 0.208 & 0.237 \\
\hline Israel & . & . & . & & . & (2) & . & 0.462 & 0.348 \\
\hline Italy & 14 & 14 & 14 & 0.385 & 0.385 & 0.385 & 0.680 & 0.724 & 0.268 \\
\hline Japan & 15 & 15 & 15 & 0.280 & 0.250 & 0.250 & 0.293 & 0.277 & 0.249 \\
\hline Korea & 14 & 14 & 14 & 0.429 & 0.429 & 0.333 & . & 0.432 & 0.321 \\
\hline Latvia & 16 & 16 & 16 & 0.182 & 0.250 & 0.250 & . & & . \\
\hline Luxembourg & 12 & 12 & 13 & 0.538 & 0.538 & 0.462 & 0.644 & 0.640 & 0.640 \\
\hline Macao (China) & . & 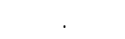 & & & . & & . & 0.572 & 0.433 \\
\hline Mexico & 12 & 12 & 12 & 0.500 & 0.500 & 0.455 & . & 0.174 & 0.114 \\
\hline Netherlands & 12 & 13 & 12 & 0.440 & 0.360 & 0.500 & 0.521 & 0.704 & 0.692 \\
\hline New Zealand & 18 & 18 & 16 & 0.000 & 0.000 & 0.154 & 0.215 & 0.380 & 0.372 \\
\hline Norway & 16 & 16 & 16 & 0.250 & 0.231 & 0.167 & 0.567 & 0.552 & 0.580 \\
\hline Poland & 15 & 15 & 15 & 0.360 & 0.360 & 0.385 & 0.746 & 0.703 & 0.609 \\
\hline Portugal & 15 & 15 & 15 & 0.250 & 0.250 & 0.250 & 0.102 & 0.244 & 0.288 \\
\hline Russian Federation & 15 & 15 & 15 & 0.273 & 0.238 & 0.217 & 0.436 & 0.419 & 0.329 \\
\hline Slovakia & 10 & 10 & 11 & 0.667 & 0.692 & 0.615 & . & & 0.764 \\
\hline Slovenia & 15 & 15 & 15 & 0.333 & 0.308 & 0.333 & . & & . \\
\hline Spain & 14 & 16 & 16 & 0.360 & 0.167 & 0.167 & 0.416 & 0.398 & 0.380 \\
\hline Sweden & 16 & 16 & 16 & 0.250 & 0.250 & 0.250 & 0.771 & 0.560 & 0.496 \\
\hline Switzerland & 15.5 & 15.5 & 15 & 0.296 & 0.296 & 0.273 & 0.756 & 0.693 & 0.646 \\
\hline Thailand & . & . & . & . & . & . & . & 0.280 & 0.240 \\
\hline Tunisia & . & . & . & . & . & . & . & . & 0.041 \\
\hline Turkey & 12 & 12 & 11 & 0.500 & 0.500 & 0.545 & 0.407 & 0.436 & 0.394 \\
\hline United Kingdom & 16 & 16 & 16 & 0.154 & 0.154 & 0.154 & 0.443 & 0.579 & 0.721 \\
\hline United States & 18 & 18 & 18 & 0.000 & 0.000 & 0.000 & 0.000 & 0.000 & 0.000 \\
\hline Uruguay & . & . & . & . & . & . & . & 0.203 & 0.192 \\
\hline
\end{tabular}

Sources: see Appendix 2

Table 2 - Pair wise correlation of school system measures - mid 80's and mid 90's

\begin{tabular}{|c|c|c|c|c|c|c|}
\hline & $\begin{array}{l}\text { fraction of } \\
\text { primary+ } \\
\text { secondary } \\
\text { education in } \\
\text { tracking }\end{array}$ & $\begin{array}{l}\text { share of } \\
\text { students in } \\
\text { upper } \\
\text { secondary } \\
\text { vocational }\end{array}$ & $\begin{array}{c}\text { enrolment in } \\
\text { pre-primary } \\
\text { education }\end{array}$ & $\begin{array}{c}\text { share of } \\
\text { secondary } \\
\text { school students } \\
\text { in private } \\
\text { schools }\end{array}$ & $\begin{array}{l}\text { expenditure } \\
\text { from public } \\
\text { sources in } \\
\text { education over } \\
\text { GDP }\end{array}$ & $\begin{array}{l}\text { student-teacher } \\
\text { ratio in } \\
\text { secondary } \\
\text { school }\end{array}$ \\
\hline $\begin{array}{l}\text { fraction of primary+ secondary } \\
\text { education in tracking }\end{array}$ & $\begin{array}{c}1.0000 \\
68\end{array}$ & & & & & \\
\hline share of students in upper & $0.5900^{*}$ & 1.0000 & & & & \\
\hline secondary vocational & 57 & 66 & & & & \\
\hline enrolment in pre-primary education & $\begin{array}{l}0.3699 * \\
57\end{array}$ & $\begin{array}{l}0.4262^{*} \\
66\end{array}$ & $\begin{array}{c}1.0000 \\
66\end{array}$ & & & \\
\hline share of secondary school & 0.0590 & -0.0640 & -0.0653 & 1.0000 & & \\
\hline students in private schools & 58 & 65 & 65 & 66 & & \\
\hline expenditure from public sources in & -0.1614 & 0.2171 & $0.3416^{*}$ & -0.0815 & 1.0000 & \\
\hline education over GDP & 56 & 55 & 55 & 55 & 57 & \\
\hline student-teacher ratio in secondary & -0.1460 & -0.1145 & -0.2434 & 0.1204 & -0.2538 & 1.0000 \\
\hline school & 50 & 50 & 50 & 50 & 49 & 52 \\
\hline
\end{tabular}

Source: see Appendix 2 - * indicates statistical significance at 5\% - figures in italics report the number of observations 
Table 3 - Descriptive statistics (unweighed)

\begin{tabular}{|c|c|c|c|c|c|c|c|c|c|}
\hline & \multicolumn{2}{|c|}{ ECHP } & \multicolumn{2}{|c|}{ ISSP } & \multicolumn{2}{|c|}{ ISSP } & \multicolumn{2}{|c|}{ IALS } & PISA \\
\hline year of survey(s) & \multicolumn{2}{|c|}{$\begin{array}{l}1995 \\
2000\end{array}$} & \multicolumn{2}{|c|}{ 1991-1999 } & \multicolumn{2}{|c|}{1999} & \multicolumn{2}{|c|}{ 1994-1996-1998 } & 2003 \\
\hline birth year of cohort 1 & \multicolumn{2}{|c|}{$1971-75$} & \multicolumn{2}{|c|}{$1967-73$} & \multirow{2}{*}{\multicolumn{2}{|c|}{$\begin{array}{l}1965-1971 \\
1975-1981\end{array}$}} & \multicolumn{2}{|c|}{$1962-67$} & 1988 \\
\hline birth year of cohort 2 & \multicolumn{2}{|c|}{$1976-80$} & \multicolumn{2}{|c|}{ 1975-81 } & & & \multicolumn{2}{|c|}{$1972-77$} & - \\
\hline & cohort 1 & cohort 2 & cohort 1 & cohort 2 & cohort 1 & cohort 2 & cohort 1 & cohort 2 & \\
\hline observations & 16163 & 15911 & 447 & 611 & 3405 & 3251 & 7421 & 6029 & 275369 \\
\hline age & 21.97 & 22.03 & 21.78 & 21.05 & 30.96 & 21.14 & 31.24 & 21.24 & 15.79 \\
\hline male & 50.01 & 46.71 & 46.53 & 43.04 & 47.47 & 47.57 & 44.09 & 47.40 & 49.59 \\
\hline $\begin{array}{l}\text { drop-out (without } \\
\text { scn.degree) }\end{array}$ & 33.69 & 33.20 & 33.18 & 42.78 & 31.92 & 31.74 & 31.20 & 31.46 & \\
\hline college enrol/completed & 27.64 & 28.75 & 47.98 & 32.82 & 23.53 & 31.51 & 27.71 & 15.36 & \\
\hline $\begin{array}{l}\text { years of education } \\
\text { (mean and sd) }\end{array}$ & & & $\begin{array}{l}11.62 \\
(2.27)\end{array}$ & $\begin{array}{l}12.01 \\
(1.96)\end{array}$ & $\begin{array}{l}13.12 \\
(3.94)\end{array}$ & $\begin{array}{l}12.27 \\
(2.61)\end{array}$ & $\begin{array}{l}12.66 \\
(3.31)\end{array}$ & $\begin{array}{l}12.30 \\
(2.56)\end{array}$ & \\
\hline $\begin{array}{l}\text { log literacy skill } \\
\text { (average across areas) } \\
\text { (mean and sd) }\end{array}$ & & & & & & & $\begin{array}{c}5.62 \\
(0.22)\end{array}$ & $\begin{array}{c}5.62 \\
(0.21)\end{array}$ & $\begin{array}{l}6.15 \\
(0.21)\end{array}$ \\
\hline employed & 45.50 & 45.29 & 62.75 & 60.67 & 77.62 & 48.53 & 74.52 & 46.41 & \\
\hline on-the-job training & 17.32 & 16.95 & & & & & 44.55 & 53.09 & \\
\hline $\begin{array}{l}\text { log wage } \\
\text { (mean and sd) }\end{array}$ & $\begin{array}{c}5.42 \\
(2.04)\end{array}$ & $\begin{array}{c}5.59 \\
(2.06)\end{array}$ & $\begin{array}{c}8.65 \\
(1.07)\end{array}$ & $\begin{array}{c}9.15 \\
(1.41)\end{array}$ & $\begin{array}{c}8.52 \\
(2.32)\end{array}$ & $\begin{array}{c}8.07 \\
(2.40)\end{array}$ & & & \\
\hline $\begin{array}{l}\text { both parent without } \\
\text { secondary education }\end{array}$ & 35.43 & 29.28 & 35.43 & 29.28 & 29.99 & 18.03 & 54.71 & 39.26 & 30.38 \\
\hline $\begin{array}{l}\text { at least one parent with } \\
\text { secondary education }\end{array}$ & 23.56 & 25.66 & 23.56 & 25.66 & 45.55 & 47.34 & 26.98 & 33.95 & 27.97 \\
\hline $\begin{array}{l}\text { at least one parent with } \\
\text { college degree }\end{array}$ & 41.01 & 45.06 & 41.01 & 45.06 & 24.46 & 34.64 & 18.31 & 26.79 & 41.65 \\
\hline books at home & & & & & 125.18 & 145.10 & & & 158.43 \\
\hline number of countries & $\begin{array}{c}\text { 12 (Austrit } \\
\text { Denmark } \\
\text { France, } \\
\text { Greece, Ir } \\
\text { Portugal, S } \\
\text { King }\end{array}$ & $\begin{array}{l}\text { Belgium, } \\
\text { Finland, } \\
\text { ermany, } \\
\text { and, Italy, } \\
\text { ain, United } \\
\text { om) }\end{array}$ & $\begin{array}{r}6 \text { (Australi } \\
\text { (both East } \\
\text { Hungar } \\
\text { Slovenia } \\
\text { St }\end{array}$ & $\begin{array}{l}\text { Germany } \\
\text { and West), } \\
\text { Poland, } \\
\text { nd United } \\
\text { tes }\end{array}$ & $\begin{array}{r}21 \text { (Austra } \\
\text { Chile, Cze } \\
\text { France, } \\
\text { Hungary, I } \\
\text { Latvia, N } \\
\text { Norway, } \\
\text { Poland, } \\
\text { Russian } \\
\text { Slovakia } \\
\text { Spain, Sw } \\
\text { St }\end{array}$ & $\begin{array}{l}\text { Canada, } \\
\text { Republic, } \\
\text { ermany, } \\
\text { Rel, Japan, } \\
\text { Zealand, } \\
\text { ilippines, } \\
\text { ortugal, } \\
\text { deration, } \\
\text { :lovenia, } \\
\text { en, United } \\
\text { s) }\end{array}$ & $\begin{array}{c}17 \text { (Belgi } \\
\text { Czech } \\
\text { Denmark } \\
\text { Germany } \\
\text { Irelan, } \\
\text { Netherla } \\
\text { Zealand, } \\
\text { Poland, } \\
\text { Sweden, } \\
\text { United Kin } \\
\text { United }\end{array}$ & $\begin{array}{l}\text { m, Chile, } \\
\text { epublic, } \\
\text { Finland, } \\
\text { Hungary, } \\
\text { Italy, } \\
\text { ds, New } \\
\text { Nowray, } \\
\text { lovenia, } \\
\text { witzerland, } \\
\text { gdom and } \\
\text { states) }\end{array}$ & $\begin{array}{l}41 \text { (Australia, Austria, } \\
\text { Belgium, Brazil, } \\
\text { Canada, Czech } \\
\text { Republic, Denmark, } \\
\text { Finland, France, } \\
\text { Germany, Greece, } \\
\text { Hong Kong (China), } \\
\text { Hungary, Iceland, } \\
\text { Indonesia, Ireland, Italy, } \\
\text { Japan, Korea, Latvia, } \\
\text { Liechtenstein, } \\
\text { Luxembourg, Macao } \\
\text { (China), Mexico, } \\
\text { Netherlands, New } \\
\text { Zealand, Norway, } \\
\text { Poland, Portugal, } \\
\text { Russian Federation, } \\
\text { Slovakia, Spain, } \\
\text { Sweden, Switzerland, } \\
\text { Thailand, , Tunisia, } \\
\text { Turkey, United } \\
\text { Kingdom, United } \\
\text { States, Uruguay, Serbia } \\
\text { and Montenegro) } \\
\end{array}$ \\
\hline
\end{tabular}


Table 4 - Determinants of educational attainments (ols)

\begin{tabular}{|c|c|c|c|c|}
\hline Dep.var.: years of education & \multicolumn{4}{|c|}{ IALS+ISSP1999 (18-24 and 28-34) } \\
\hline $\begin{array}{l}\text { family background } \\
\text { fam.background*tracking length } \\
\text { fam.background*vocational share in upp.secondary } \\
\text { fam.background*length*share in vocational }\end{array}$ & $\begin{array}{c}1.0256 \\
{[7.82]^{\star \star \star}} \\
0.6781 \\
{[1.79]^{\star}}\end{array}$ & $\begin{array}{c}1.3526 \\
{[4.70]^{\star \star \star}}\end{array}$ & $\begin{array}{c}1.2965 \\
{[4.90]^{\star \star \star}} \\
1.3544 \\
{[2.24]^{\star \star}} \\
-0.9396 \\
{[1.40]}\end{array}$ & $\begin{array}{c}0.9348 \\
{[6.90]^{\star \star *}} \\
2.4254 \\
{[1.60]}\end{array}$ \\
\hline $\begin{array}{l}\text { Observations } \\
\text { R-squared } \\
\text { Log likelihood }\end{array}$ & $\begin{array}{c}14038 \\
0.38 \\
-33993.83 \\
24 \\
\text { (excluded } \\
\text { Chile } \\
1985) \\
\end{array}$ & $\begin{array}{c}14038 \\
0.38 \\
-33999.86 \\
24 \\
\text { (excluded } \\
\text { Chile } \\
1985) \\
\end{array}$ & $\begin{array}{c}14038 \\
0.38 \\
-33981.5 \\
24 \\
\text { (excluded } \\
\text { Chile } \\
1985) \\
\end{array}$ & $\begin{array}{c}14038 \\
0.38 \\
-33982.71 \\
24 \\
\text { (excluded } \\
\text { Chile } \\
1985) \\
\end{array}$ \\
\hline $\begin{array}{l}\text { controlling for enrolment in pre-primary } \\
\text { family background } \\
\text { fam.background*tracking length } \\
\text { fam.background*vocational share in upp.secondary } \\
\text { fam.background*length*share in vocational } \\
\text { family background*relative enrolment in pre-primary school }\end{array}$ & $\begin{array}{c}1.0806 \\
{[5.65]^{\star \star \star}} \\
0.8054 \\
{[1.66]}\end{array}$ & $\begin{array}{c}1.3008 \\
{[3.99]^{\star \star \star}} \\
\\
-0.3055 \\
{[0.66]}\end{array}$ & $\begin{array}{c}1.3407 \\
{[4.18]^{\star \star \star}} \\
1.4563 \\
{[1.93]^{\star}} \\
-0.9312 \\
{[1.41]}\end{array}$ & $\begin{array}{c}0.9501 \\
{[5.78]^{\star \star \star}} \\
2.4318 \\
{[1.58]} \\
\\
\\
-2.4362 \\
{[1.29]} \\
-0.0617 \\
{[0.15]} \\
\end{array}$ \\
\hline $\begin{array}{l}\text { controlling for student/teacher ratio in secondary school } \\
\text { family background } \\
\text { fam.background*tracking length } \\
\text { fam.background*vocational share in upp.secondary } \\
\text { fam.background*length*share in vocational } \\
\text { family background*pupil teacher ratio secnd.school }\end{array}$ & $\begin{array}{c}0.6913 \\
{[1.18]} \\
0.8418 \\
{[1.59]}\end{array}$ & $\begin{array}{c}-0.2125 \\
{[0.39]}\end{array}$ & $\begin{array}{c}1.1016 \\
{[1.68]} \\
1.3918 \\
{[2.14]^{\star \star}} \\
-0.8715 \\
{[1.28]}\end{array}$ & $\begin{array}{l}0.6545 \\
{[1.15]} \\
2.4774 \\
{[1.52]} \\
\\
-2.3518 \\
{[1.18]} \\
0.0173 \\
{[0.51]} \\
\end{array}$ \\
\hline $\begin{array}{l}\text { controlling for educational expenditure over GDP } \\
\text { family background } \\
\text { fam.background*tracking length } \\
\text { fam. background*vocational share in upp.secondary } \\
\text { fam.background*length*share in vocational } \\
\text { fam.background*school expenditure on GDP }\end{array}$ & $\begin{array}{c}2.5068 \\
{[3.35]^{\star \star \star}} \\
0.5578 \\
{[1.30]}\end{array}$ & $\begin{array}{c}2.7156 \\
{[3.52]^{\star \star \star}}\end{array}$ & $\begin{array}{c}2.5093 \\
{[3.40]^{\star \star \star}} \\
0.9109 \\
{[1.64]} \\
-0.4761 \\
{[0.83]}\end{array}$ & $\begin{array}{c}-1.6362 \\
{[0.99]} \\
-0.2395 \\
{[2.22]^{\star \star}}\end{array}$ \\
\hline $\begin{array}{l}\text { controlling for private student share in secondary school } \\
\text { family background } \\
\text { fam.background*tracking length } \\
\text { fam.background*vocational share in upp.secondary } \\
\text { fam.background*length*share in vocational } \\
\text { family background*share of private up.secnd.schools }\end{array}$ & $\begin{array}{c}1.0751 \\
{[7.81]^{\star \star \star}} \\
0.7739 \\
{[2.02]^{\star \star}}\end{array}$ & $\begin{array}{c}1.4133 \\
{[4.70]^{\star \star *}}\end{array}$ & $\begin{array}{c}1.3918 \\
{[4.90]^{\star \star \star}} \\
1.5568 \\
{[2.33]^{\star \star}} \\
-1.0503 \\
{[1.51]}\end{array}$ & $\begin{array}{c}-3.2495 \\
{[1.36]} \\
-0.6473 \\
{[1.60]}\end{array}$ \\
\hline
\end{tabular}

Weighed - Robust standard errors clustered by country $\times$ wave - $t$ statistics in brackets -

* significant at 10\%; ** significant at 5\%; *** significant at 1\% - Country ${ }^{*} y e a r$, gender, age controls included. 
Table 5 - Probability of non attainment of a secondary degree (probit marginal effect)

\begin{tabular}{|c|c|c|c|c|c|c|c|c|}
\hline Dep.var.: 1=non possessing a secondary degree & IAL: & ISSP1999 & $18-24$ and 2 & 3-34) & & CHP+ISSP & $91 / 99(18-2$ & \\
\hline $\begin{array}{l}\text { family background } \\
\text { fam.background*tracking length } \\
\text { fam.background*vocational share in upp.secondary } \\
\text { fam.background*length*share in vocational }\end{array}$ & $\begin{array}{c}-0.1209 \\
{[6.22]^{\star \star \star}} \\
-0.1342 \\
{[2.64]^{\star \star \star}}\end{array}$ & $\begin{array}{c}-0.1484 \\
{[4.10]^{\star \star \star}} \\
\\
-0.0249 \\
{[0.37]}\end{array}$ & $\begin{array}{c}-0.1441 \\
{[4.13]^{\star \star \star}} \\
-0.1926 \\
{[2.35]^{\star \star}} \\
0.0804 \\
{[0.87]}\end{array}$ & $\begin{array}{c}-0.1144 \\
{[5.13]^{\star \star \star}} \\
-0.2582 \\
{[1.36]} \\
\\
\\
0.1738 \\
{[0.75]} \\
\end{array}$ & $\begin{array}{c}-0.0994 \\
{[2.98]^{\star \star \star}} \\
0.0105 \\
{[0.11]}\end{array}$ & $\begin{array}{c}-0.09 \\
{[2.45]^{\star \star}} \\
\\
-0.0126 \\
{[0.18]}\end{array}$ & $\begin{array}{c}-0.0939 \\
{[2.37]^{\star \star}} \\
0.0363 \\
{[0.39]} \\
-0.0304 \\
{[0.44]}\end{array}$ & $\begin{array}{c}-0.1285 \\
{[4.21]^{\star * \star}} \\
0.3103 \\
{[2.31]^{\star \star}}\end{array}$ \\
\hline $\begin{array}{l}\text { Observations } \\
\text { Pseudo R-squared } \\
\text { Log likelihood }\end{array}$ & $\begin{array}{c}14330 \\
0.19 \\
-7035.44 \\
24 \\
\text { (excluded } \\
\text { Chile } \\
1985 \text { ) }\end{array}$ & $\begin{array}{c}14330 \\
0.19 \\
-7044.54 \\
24 \\
\text { (excluded } \\
\text { Chile } \\
1985) \\
\end{array}$ & $\begin{array}{c}14330 \\
0.19 \\
-7032.72 \\
24 \\
\text { (excluded } \\
\text { Chile } \\
1985) \\
\end{array}$ & $\begin{array}{c}14330 \\
0.19 \\
-7033.74 \\
24 \\
\text { (excluded } \\
\text { Chile } \\
1985 \text { ) }\end{array}$ & $\begin{array}{c}17655 \\
0.19 \\
-8009.76 \\
16\end{array}$ & $\begin{array}{c}17655 \\
0.19 \\
-8009.61 \\
16\end{array}$ & $\begin{array}{c}17655 \\
0.19 \\
-8008.92 \\
16\end{array}$ & $\begin{array}{c}17655 \\
0.19 \\
-7989.81\end{array}$ \\
\hline $\begin{array}{l}\text { controlling for enrolment in pre-primary } \\
\text { family background } \\
\text { fam.background*tracking length } \\
\text { fam.background*vocational share in upp.secondary } \\
\text { fam.background*length*share in vocational } \\
\text { family backgroundrelative enrolment in pre-primary school }\end{array}$ & $\begin{array}{l}-0.1362 \\
{[5.92]^{\star \star \star}} \\
-0.1645 \\
{[2.44]^{\star *}}\end{array}$ & $\begin{array}{c}-0.148 \\
{[3.96]^{\star \star \star}} \\
\\
-0.0244 \\
{[0.34]}\end{array}$ & $\begin{array}{c}-0.1573 \\
{[4.21]^{\star \star \star}} \\
-0.2186 \\
{[2.20]^{\star \star}} \\
0.0772 \\
{[0.83]}\end{array}$ & $\begin{array}{l}-0.1283 \\
{[5.08]^{\star \star \star}} \\
-0.2622 \\
{[1.37]} \\
\\
0.1437 \\
{[0.62]} \\
0.052 \\
{[0.78]}\end{array}$ & $\begin{array}{c}-0.0894 \\
{[2.62]^{\star \star \star}} \\
0.0592 \\
{[0.59]}\end{array}$ & $\begin{array}{c}-0.083 \\
{[2.29]^{\star \star}} \\
0.0073 \\
{[0.09]}\end{array}$ & $\begin{array}{c}-0.087 \\
{[2.42]^{\star \star}} \\
0.0703 \\
{[0.73]} \\
-0.0165 \\
{[0.21]}\end{array}$ & $\begin{array}{c}-0.3956 \\
{[2.25]^{\star *}} \\
0.0099 \\
{[0.12]}\end{array}$ \\
\hline $\begin{array}{l}\text { controlling for student/teacher ratio in secondary school } \\
\text { family background } \\
\text { fam.background*tracking length } \\
\text { fam.background*vocational share in upp.secondary } \\
\text { fam.background*length*share in vocational } \\
\text { family background*xupil teacher ratio secnd.school }\end{array}$ & $\begin{array}{c}-0.0241 \\
{[0.35]} \\
-0.1822 \\
{[2.72]^{\star \star \star}}\end{array}$ & $\begin{array}{c}-0.079 \\
{[0.97]} \\
\\
-0.0525 \\
{[0.70]}\end{array}$ & $\begin{array}{c}-0.0484 \\
{[0.63]} \\
-0.2189 \\
{[2.49]^{\star *}} \\
0.056 \\
{[0.60]}\end{array}$ & $\begin{array}{c}-0.019 \\
{[0.27]} \\
-0.3049 \\
{[1.44]} \\
\\
0.173 \\
{[0.69]} \\
-0.006 \\
{[1.68]^{\star}}\end{array}$ & $\begin{array}{c}-0.1039 \\
{[1.50]} \\
0.0115 \\
{[0.12]}\end{array}$ & $\begin{array}{c}-0.09 \\
{[1.24]} \\
\\
-0.0126 \\
{[0.17]}\end{array}$ & $\begin{array}{c}-0.0967 \\
{[1.27]} \\
0.0368 \\
{[0.39]} \\
-0.0302 \\
{[0.43]}\end{array}$ & $\begin{array}{c}-0.3979 \\
{[2.41]^{\star \star}} \\
-0.0015 \\
{[0.44]}\end{array}$ \\
\hline $\begin{array}{l}\text { controlling for educational expenditure over GDP } \\
\text { family background } \\
\text { fam.background*tracking length } \\
\text { fam.background*vocational share in upp.secondary } \\
\text { fam.background*lengthshare in vocational } \\
\text { fam.background*school expenditure on GDP }\end{array}$ & $\begin{array}{l}-0.2923 \\
{[3.37]^{\star \star \star}} \\
-0.1242 \\
{[2.24]^{\star \star}}\end{array}$ & $\begin{array}{c}-0.3213 \\
{[3.58]^{\star \star \star}} \\
\\
-0.0562 \\
{[0.86]}\end{array}$ & $\begin{array}{c}-0.2926 \\
{[3.38]^{\star \star \star}} \\
-0.1437 \\
{[1.83]^{\star}} \\
0.0266 \\
{[0.30]}\end{array}$ & $\begin{array}{c}-0.2836 \\
{[3.24]^{\star \star \star}} \\
-0.1976 \\
{[1.11]} \\
\\
\\
0.1029 \\
{[0.47]} \\
0.0287 \\
{[1.90]^{\star}}\end{array}$ & $\begin{array}{c}-0.0125 \\
{[0.16]} \\
0.0367 \\
{[0.44]}\end{array}$ & $\begin{array}{c}-0.0106 \\
{[0.14]} \\
\\
0.0129 \\
{[0.19]}\end{array}$ & $\begin{array}{c}-0.0134 \\
{[0.17]} \\
0.0421 \\
{[0.47]} \\
-0.0071 \\
{[0.10]}\end{array}$ & $\begin{array}{c}-0.3532 \\
{[2.41]^{\star \star}} \\
-0.0105 \\
{[0.77]}\end{array}$ \\
\hline $\begin{array}{l}\text { controlling for private student share in secondary school } \\
\text { family background } \\
\text { fam.background*tracking length } \\
\text { fam.background*vocational share in upp.secondary } \\
\text { fam.background*length*share in vocational } \\
\text { family background*share of private up.secnd.schools }\end{array}$ & $\begin{array}{l}-0.1217 \\
{[5.47]^{\star \star \star}} \\
-0.1351 \\
{[2.70]^{\star \star \star}}\end{array}$ & $\begin{array}{c}-0.0083 \\
{[0.16]} \\
\end{array}$ & $\begin{array}{c}-0.1456 \\
{[3.97]^{\star \star \star}} \\
-0.1948 \\
{[2.37]^{\star \star}} \\
0.0813 \\
{[0.87]}\end{array}$ & $\begin{array}{c}-0.1162 \\
{[4.94]^{\star * *}} \\
-0.2733 \\
{[1.30]}\end{array}$ & $\begin{array}{c}-0.1236 \\
{[3.65]^{\star \star \star}} \\
0.0192 \\
{[0.22]}\end{array}$ & $\begin{array}{l}-0.1212 \\
{[2.96]^{\star \star \star}}\end{array}$ & $\begin{array}{c}-0.1229 \\
{[2.94]^{\star \star \star}} \\
0.0213 \\
{[0.23]} \\
-0.0026 \\
{[0.04]}\end{array}$ & $\begin{array}{c}-0.3252 \\
{[2.21]^{\star *}} \\
0.0564 \\
{[0.94]}\end{array}$ \\
\hline
\end{tabular}

Weighed - Robust standard errors clustered by country $\times$ wave - $t$ statistics in brackets -

* significant at 10\%; ** significant at 5\%; ** significant at $1 \%$ - Country*year, gender, age controls included. 
Table 6 - Probability of college enrolment/attainment (probit marginal effect)

\begin{tabular}{|c|c|c|c|c|c|c|c|c|}
\hline Dep.var.: 1=college enrolment/college attained & IALS & HSSP1999 & $18-24$ and 2 & 3-34) & & SHP+ISSP & $91 / 99(18-2$ & \\
\hline $\begin{array}{l}\text { family background } \\
\text { fam.background*tracking length } \\
\text { fam.background*vocational share in upp.secondary } \\
\text { fam.background*lengthshare in vocational }\end{array}$ & $\begin{array}{c}0.138 \\
{[7.94]^{\star \star \star}} \\
0.0513 \\
{[0.93]}\end{array}$ & $\begin{array}{c}0.1887 \\
{[7.79]^{\star \star \star}} \\
\\
-0.0721 \\
{[1.61]}\end{array}$ & $\begin{array}{c}0.1796 \\
{[8.42]^{\star \star \star}} \\
0.1456 \\
{[2.26]^{\star \star}} \\
-0.1396 \\
{[2.74]^{\star \star \star}}\end{array}$ & $\begin{array}{c}0.129 \\
{[7.39]^{\star \star \star}} \\
0.2727 \\
{[2.26]^{\star \star}} \\
\\
-0.3344 \\
{[2.01]^{\star \star}} \\
\end{array}$ & $\begin{array}{l}0.1073 \\
{[2.34]^{\star \star}} \\
0.0478 \\
{[0.38]}\end{array}$ & $\begin{array}{c}0.0953 \\
{[2.02]^{\star \star}} \\
\\
0.0605 \\
{[0.65]}\end{array}$ & $\begin{array}{c}0.0952 \\
{[1.70]^{*}} \\
0.0006 \\
{[0.00]} \\
0.0602 \\
{[0.74]}\end{array}$ & $\begin{array}{c}0.1485 \\
{[3.54]^{\star \star \star}} \\
-0.409 \\
{[2.47]^{\star \star}}\end{array}$ \\
\hline $\begin{array}{l}\text { Observations } \\
\text { Pseudo R-squared } \\
\text { Log likelihood }\end{array}$ & $\begin{array}{c}14275 \\
0.16 \\
-6798.98 \\
24 \\
\text { (excluded } \\
\text { Chile } \\
1985)\end{array}$ & $\begin{array}{c}14275 \\
0.16 \\
-6795.98 \\
24 \\
\text { (excluded } \\
\text { Chile } \\
1985 \text { ) }\end{array}$ & $\begin{array}{c}14275 \\
0.16 \\
-6786.96 \\
24 \\
\text { (excluded } \\
\text { Chile } \\
1985)\end{array}$ & $\begin{array}{c}14275 \\
0.16 \\
-6790.69 \\
24 \\
\text { (excluded } \\
\text { Chile } \\
1985 \text { ) }\end{array}$ & $\begin{array}{c}17628 \\
0.2 \\
-9515.35\end{array}$ & $\begin{array}{c}17628 \\
0.2 \\
-9513.24\end{array}$ & $\begin{array}{c}17628 \\
0.2 \\
-9513.24\end{array}$ & $\begin{array}{c}17628 \\
0.2 \\
-9481.63\end{array}$ \\
\hline $\begin{array}{l}\text { controlling for enrolment in pre-primary } \\
\text { family background } \\
\text { fam.background*tracking length } \\
\text { fam.background*vocational share in upp.secondary } \\
\text { fam.background*lengthshare in vocational } \\
\text { family background*relative enrolment in pre-primary school }\end{array}$ & $\begin{array}{c}0.1322 \\
{[5.98]^{\star \star \star}} \\
0.0381 \\
{[0.63]}\end{array}$ & $\begin{array}{l}0.1721 \\
{[6.02]^{\star \star}} \\
\\
-0.0904 \\
{[2.06]^{\star \star}}\end{array}$ & $\begin{array}{c}0.173 \\
{[6.71]^{\star \star \star}} \\
0.1303 \\
{[1.86]^{\star}} \\
-0.1407 \\
{[2.73]^{\star \star \star}}\end{array}$ & $\begin{array}{l}0.1164 \\
{[5.39]^{\star \star \star}} \\
0.2667 \\
{[2.16]^{\star \star}} \\
\\
-0.3664 \\
{[2.21]^{\star \star}} \\
0.0537 \\
{[1.06]}\end{array}$ & $\begin{array}{l}0.1028 \\
{[2.22]^{\star \star}} \\
0.0297 \\
{[0.21]}\end{array}$ & $\begin{array}{l}0.0936 \\
{[2.02]^{\star *}} \\
\\
0.0561 \\
{[0.51]}\end{array}$ & $\begin{array}{c}0.094 \\
{[1.79]^{\star}} \\
-0.0045 \\
{[0.03]} \\
0.0575 \\
{[0.60]}\end{array}$ & $\begin{array}{c}0.7621 \\
{[3.94]^{\star * \star}} \\
-0.1304 \\
{[1.45]}\end{array}$ \\
\hline $\begin{array}{l}\text { controlling for studenttteacher ratio in secondary school } \\
\text { family background } \\
\text { fam.background*tracking length } \\
\text { fam.background*vocational share in upp.secondary } \\
\text { fam.background*length*share in vocational } \\
\text { family background*pupil teacher ratio secnd.school }\end{array}$ & $\begin{array}{l}0.0901 \\
{[2.04]^{\star \star}} \\
0.0774 \\
{[1.39]}\end{array}$ & $\begin{array}{c}0.1835 \\
{[3.51]^{\star * \star}} \\
\\
-0.0685 \\
{[1.50]}\end{array}$ & $\begin{array}{c}0.1537 \\
{[3.13]^{\star \star \star}} \\
0.1515 \\
{[2.50]^{\star \star}} \\
-0.1296 \\
{[2.41]^{\star \star}}\end{array}$ & $\begin{array}{l}0.0895 \\
{[2.08]^{\star \star}} \\
0.2736 \\
{[2.24]^{\star \star}} \\
\\
-0.3027 \\
{[1.85]^{\star}} \\
0.0023 \\
{[0.96]}\end{array}$ & $\begin{array}{c}0.1361 \\
{[1.58]} \\
0.0406 \\
{[0.31]}\end{array}$ & $\begin{array}{l}0.1184 \\
{[1.30]} \\
\\
0.056 \\
{[0.58]}\end{array}$ & $\begin{array}{c}0.1189 \\
{[1.18]} \\
-0.0029 \\
{[0.02]} \\
0.0573 \\
{[0.67]}\end{array}$ & $\begin{array}{l}0.1262 \\
{[1.77]^{\star}} \\
-0.4151 \\
{[2.45]^{\star \star}}\end{array}$ \\
\hline $\begin{array}{l}\text { controlling for educational expenditure over GDP } \\
\text { family background } \\
\text { fam.background*tracking length } \\
\text { fam.background*vocational share in upp.secondary } \\
\text { fam.background*lengthshare in vocational } \\
\text { fam.background*school expenditure on GDP }\end{array}$ & $\begin{array}{c}0.2436 \\
{[4.20]^{\star * \star}} \\
0.0444 \\
{[0.85]}\end{array}$ & $\begin{array}{c}0.2737 \\
{[4.83]^{\star \star \star}} \\
\\
-0.0517 \\
{[1.18]}\end{array}$ & $\begin{array}{c}0.2442 \\
{[4.58]^{\star \star \star}} \\
0.1232 \\
{[2.00]^{\star \star}} \\
-0.1132 \\
{[2.25]^{\star \star}}\end{array}$ & $\begin{array}{c}0.2185 \\
{[3.84]^{\star \star \star}} \\
0.2158 \\
{[1.90]^{\star}}\end{array}$ & $\begin{array}{c}0.0035 \\
{[0.05]} \\
0.0169 \\
{[0.15]}\end{array}$ & $\begin{array}{c}0.0056 \\
{[0.08]} \\
\\
0.0301 \\
{[0.33]}\end{array}$ & $\begin{array}{c}0.0061 \\
{[0.08]} \\
-0.0061 \\
{[0.05]} \\
0.0327 \\
{[0.36]}\end{array}$ & $\begin{array}{c}0.5938 \\
{[3.42]^{\star \star \star}} \\
0.0098 \\
{[0.97]} \\
\end{array}$ \\
\hline $\begin{array}{l}\text { controlling for private student share in secondary school } \\
\text { family background } \\
\text { fam.background*tracking length } \\
\text { fam.backgroundvocational share in upp.secondary } \\
\text { fam.background*lengthshare in vocational } \\
\text { family background*share of private up.secnd.schools }\end{array}$ & $\begin{array}{c}0.1457 \\
{[8.07]^{* \star *}} \\
0.0783 \\
{[1.60]}\end{array}$ & $\begin{array}{c}0.2018 \\
{[7.13]^{\star \star \star}}\end{array}$ & $\begin{array}{c}0.1974 \\
{[7.86]^{\star \star \star}} \\
0.1982 \\
{[2.81]^{\star \star \star}} \\
-0.1651 \\
{[2.86]^{\star \star \star}}\end{array}$ & $\begin{array}{l}0.1373 \\
{[8.10]^{\star \star \star}} \\
0.4145 \\
{[2.16]^{\star \star}} \\
\\
-0.4861 \\
{[2.01]^{\star \star}} \\
-0.1171 \\
{[2.38]^{\star \star}}\end{array}$ & $\begin{array}{c}0.1462 \\
{[3.36]^{\star \star \star}} \\
0.0439 \\
{[0.39]}\end{array}$ & $\begin{array}{c}0.1439 \\
{[2.89]^{* \star \star}}\end{array}$ & $\begin{array}{c}0.141 \\
{[2.56]^{\star \star}} \\
0.0274 \\
{[0.25]} \\
0.0214 \\
{[0.27]}\end{array}$ & $\begin{array}{c}0.5053 \\
{[3.18]^{\star \star \star}} \\
-0.1271 \\
{[2.39]^{\star \star}}\end{array}$ \\
\hline
\end{tabular}

Weighed - Robust standard errors clustered by country $\times$ wave $-t$ statistics in brackets -

* significant at 10\%; ** significant at 5\%; ${ }^{* *}$ significant at $1 \%$ - Country*year, gender, age controls included. 
Table 7 - Inequality in educational attainment (ols)

\begin{tabular}{|c|c|c|c|c|c|c|c|c|}
\hline Dep.var.: coefficient of variation years of education & \multicolumn{4}{|c|}{ IALS+ISSP1999 (18-24 and 28-34) } & \multicolumn{4}{|c|}{ ISSP1999 (18-24 and 28-34) } \\
\hline $\begin{array}{l}\text { cv.family background } \\
\text { cv.family background*tracking length } \\
\text { cv.family background*vocational share in upp.secondary } \\
\text { cv.family background*length }{ }^{\star} \text { share in vocational }\end{array}$ & $\begin{array}{c}-0.0135 \\
{[0.66]} \\
0.0743 \\
{[1.01]}\end{array}$ & $\begin{array}{c}0.0088 \\
{[0.36]} \\
\\
-0.0009 \\
{[0.02]}\end{array}$ & $\begin{array}{c}-0.0119 \\
{[0.50]} \\
0.1005 \\
{[1.15]} \\
-0.0196 \\
{[0.42]}\end{array}$ & $\begin{array}{c}-0.0297 \\
{[1.05]} \\
0.2331 \\
{[1.31]}\end{array}$ & $\begin{array}{l}0.0148 \\
{[0.32]} \\
0.0622 \\
{[0.48]}\end{array}$ & $\begin{array}{l}0.0151 \\
{[0.64]} \\
\\
0.0581 \\
{[1.43]}\end{array}$ & $\begin{array}{c}0 \\
{[0.00]} \\
0.0667 \\
{[0.39]} \\
0.039 \\
{[0.66]}\end{array}$ & $\begin{array}{c}-0.0234 \\
{[0.42]} \\
0.289 \\
{[1.35]}\end{array}$ \\
\hline $\begin{array}{l}\text { Observations } \\
\text { R-squared } \\
\text { Log likelihood }\end{array}$ & $\begin{array}{c}628 \\
0.63 \\
970.41 \\
\\
25\end{array}$ & $\begin{array}{c}592 \\
0.59 \\
901.67 \\
24 \\
\text { (excluded } \\
\text { Slovenia) } \\
\end{array}$ & $\begin{array}{c}592 \\
0.6 \\
907.13 \\
24 \\
\text { (excluded } \\
\text { Slovenia) } \\
\end{array}$ & $\begin{array}{c}592 \\
0.6 \\
911.64 \\
24 \\
\text { (excluded } \\
\text { Slovenia) } \\
\end{array}$ & $\begin{array}{c}388 \\
0.68 \\
597.99 \\
17\end{array}$ & $\begin{array}{c}358 \\
0.65 \\
546.82 \\
16 \\
\text { (excluded } \\
\text { Slovenia) } \\
\end{array}$ & $\begin{array}{c}358 \\
0.65 \\
547.34 \\
16 \\
\text { (excluded } \\
\text { Slovenia) } \\
\end{array}$ & $\begin{array}{c}358 \\
0.65 \\
548.95 \\
16 \\
\text { (excluded } \\
\text { Slovenia) } \\
\end{array}$ \\
\hline $\begin{array}{l}\text { controlling for enrolment in pre-primary } \\
\text { cv.family background } \\
\text { cv.family background*tracking length } \\
\text { cv.family background*vocational share in upp.secondary } \\
\text { cv.family background*lengthshare in vocational } \\
\text { cv.family background*relative enrolment in pre-primary school }\end{array}$ & $\begin{array}{c}-0.0295 \\
{[1.40]} \\
0.0228 \\
{[0.22]}\end{array}$ & $\begin{array}{c}-0.0214 \\
{[1.17]} \\
\\
-0.0122 \\
{[0.32]}\end{array}$ & $\begin{array}{c}-0.0235 \\
{[1.25]} \\
0.0295 \\
{[0.26]} \\
-0.0162 \\
{[0.37]}\end{array}$ & $\begin{array}{l}-0.0437 \\
{[1.69]^{\star}} \\
0.1741 \\
{[0.98]} \\
\\
\\
-0.265 \\
{[1.32]} \\
0.127 \\
{[1.48}\end{array}$ & $\begin{array}{c}-0.0174 \\
{[0.39]} \\
0.0733 \\
{[0.52]}\end{array}$ & $\begin{array}{c}-0.0097 \\
{[0.35]} \\
\\
0.0421 \\
{[1.32]}\end{array}$ & $\begin{array}{c}-0.0182 \\
{[0.42]} \\
0.0432 \\
{[0.24]} \\
0.0305 \\
{[0.60]}\end{array}$ & $\begin{array}{c}-0.0635 \\
{[1.23]} \\
0.3225 \\
{[1.61]} \\
\\
\\
-0.3717 \\
{[1.59]} \\
0.1293 \\
{[1.27]}\end{array}$ \\
\hline $\begin{array}{l}\text { controlling for student/teacher ratio in secondary school } \\
\text { cv.family background } \\
\text { cv.family background*tracking length } \\
\text { cv.family background*vocational share in upp.secondary } \\
\text { cv.family background*lengthshare in vocational } \\
\text { cv.family background*pupil teacher ratio secnd.school }\end{array}$ & $\begin{array}{c}-0.1117 \\
{[3.40]^{\star \star \star}} \\
0.0603 \\
{[1.19]}\end{array}$ & $\begin{array}{c}-0.1316 \\
{[3.29]^{\star \star \star}} \\
\\
0.0407 \\
{[1.29]}\end{array}$ & $\begin{array}{c}-0.1315 \\
{[3.63]^{\star \star \star}} \\
0.047 \\
{[0.89]} \\
0.0291 \\
{[0.88]}\end{array}$ & $\begin{array}{c}-0.1095 \\
{[3.56]^{\star \star \star}} \\
0.1075 \\
{[0.87]}\end{array}$ & $\begin{array}{c}-0.0783 \\
{[2.27]^{\star *}} \\
0.0113 \\
{[0.12]}\end{array}$ & $\begin{array}{c}-0.1145 \\
{[3.85]^{\star \star \star}} \\
\\
0.0764 \\
{[2.63]^{\star \star \star}}\end{array}$ & $\begin{array}{c}-0.1064 \\
{[3.03]^{\star \star \star}} \\
-0.1476 \\
{[1.29]} \\
0.1222 \\
{[3.04]^{\star \star \star}}\end{array}$ & $\begin{array}{c}-0.0755 \\
{[2.21]^{\star *}} \\
-0.0316 \\
{[0.15]}\end{array}$ \\
\hline $\begin{array}{l}\text { controlling for educational expenditure over GDP } \\
\text { cv.family background } \\
\text { cv.family background*tracking length } \\
\text { cv.family background*vocational share in upp.secondary } \\
\text { cv.family background*lengthshare in vocational } \\
\text { cv.family background*school expenditure on GDP }\end{array}$ & $\begin{array}{c}0.0361 \\
{[0.81]} \\
0.0888 \\
{[1.40]}\end{array}$ & $\begin{array}{c}-0.0144 \\
{[1.13]}\end{array}$ & $\begin{array}{l}0.0381 \\
{[0.85]} \\
0.0854 \\
{[1.35]} \\
0.0096 \\
{[0.25]}\end{array}$ & $\begin{array}{c}0.0143 \\
{[0.28]} \\
0.1988 \\
{[1.36]} \\
\\
\\
-0.1763 \\
{[0.98]} \\
-0.0083 \\
{[0.86]}\end{array}$ & $\begin{array}{c}0.0524 \\
{[0.95]} \\
0.0838 \\
{[0.72]}\end{array}$ & $\begin{array}{c}0.0801 \\
{[3.57]^{\star \star \star}} \\
\\
0.1318 \\
{[2.69]^{\star \star \star}}\end{array}$ & $\begin{array}{c}0.1413 \\
{[2.65]^{\star \star \star}} \\
-0.1673 \\
{[1.26]} \\
0.2069 \\
{[3.11]^{\star \star \star}}\end{array}$ & $\begin{array}{c}-0.129 \\
{[0.36]} \\
-0.0063 \\
{[0.63]}\end{array}$ \\
\hline $\begin{array}{l}\text { controlling for private student share in secondary school } \\
\text { cv.family background } \\
\text { cv.family background*tracking length } \\
\text { cv.family background*vocational share in upp.secondary } \\
\text { cv.family background*length*share in vocational } \\
\text { cv.family background*share of private up.secnd.schools }\end{array}$ & $\begin{array}{c}-0.0201 \\
{[0.62]} \\
0.0933 \\
{[1.18]}\end{array}$ & $\begin{array}{c}-0.0012 \\
{[0.03]}\end{array}$ & $\begin{array}{c}-0.013 \\
{[0.44]} \\
0.1004 \\
{[1.17]} \\
-0.0198 \\
{[0.42]}\end{array}$ & $\begin{array}{c}-0.028 \\
{[0.81]} \\
0.2362 \\
{[1.36]}\end{array}$ & $\begin{array}{c}-0.0297 \\
{[0.73]} \\
0.0586 \\
{[0.61]}\end{array}$ & $\begin{array}{c}-0.074 \\
{[2.95]^{\star \star \star}} \\
\\
0.1124 \\
{[4.08]^{\star \star \star}}\end{array}$ & $\begin{array}{c}-0.0597 \\
{[1.93]^{\star}} \\
-0.1446 \\
{[1.28]} \\
0.165 \\
{[3.85]^{\star \star \star}}\end{array}$ & $\begin{array}{c}-0.0178 \\
{[0.39]} \\
-0.1224 \\
{[0.48]}\end{array}$ \\
\hline & {$[0.08]$} & {$[0.10]$} & {$[0.10]$} & {$[0.16]$} & {$[3.04]^{\star \star \star}$} & {$[5.19]^{\star \star \star}$} & {$[4.80]^{\star \star \star}$} & {$[2.71]^{\star \star \star}$} \\
\hline
\end{tabular}


Table 8 - Labour market condition

(employed/unemployed/out of labour force - multinomial logit - coefficients for employed)

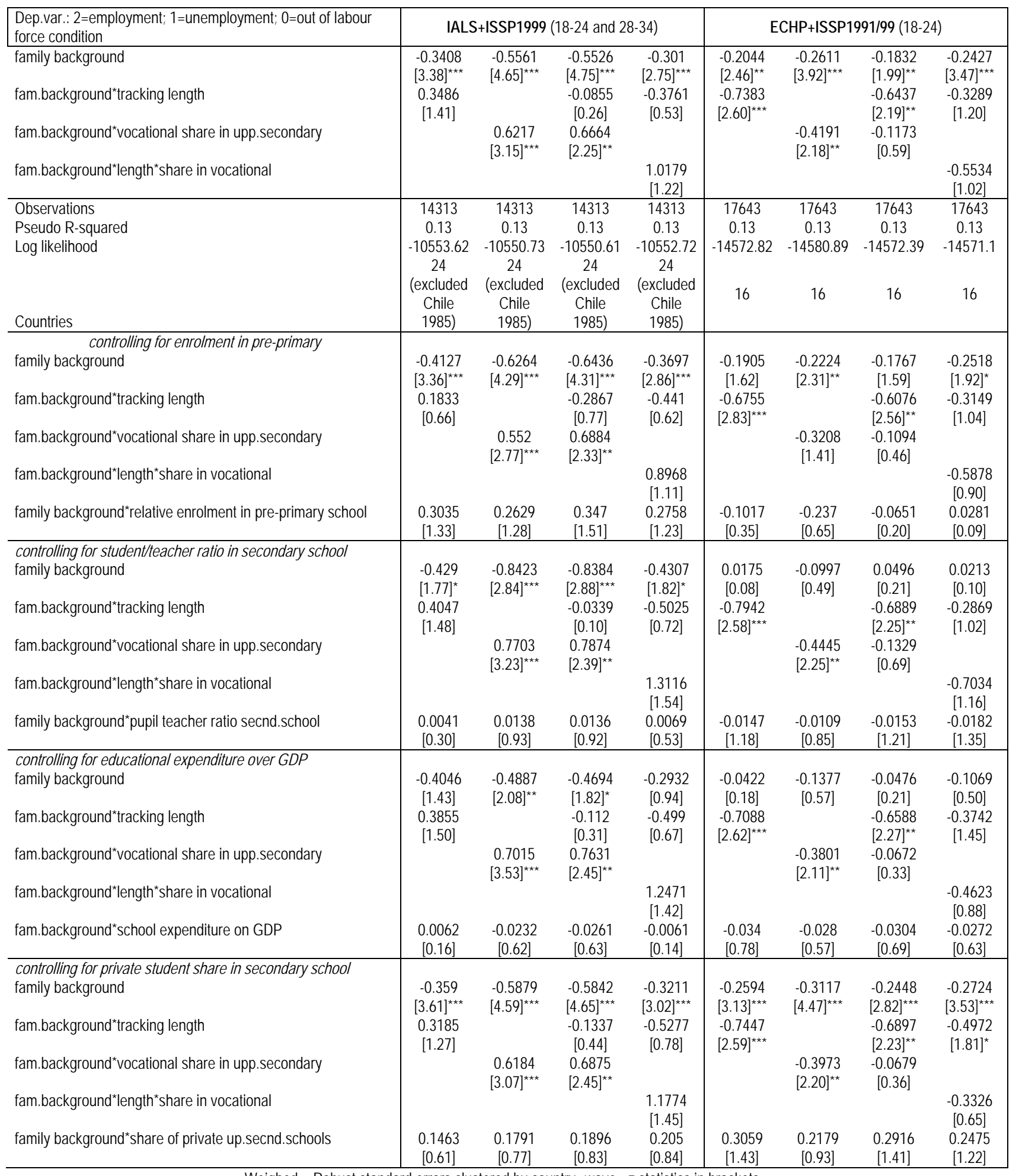

Weighed - Robust standard errors clustered by country $\times$ wave $-\mathrm{z}$ statistics in brackets -

* significant at 10\%; ** significant at 5\%; *** significant at 1\% - Country*year, gender, age controls included.

Baseline: out of labour force 
Table 9 - Wage determinants (ols) - Heckman selection equation (based on family condition and religious attitudes)

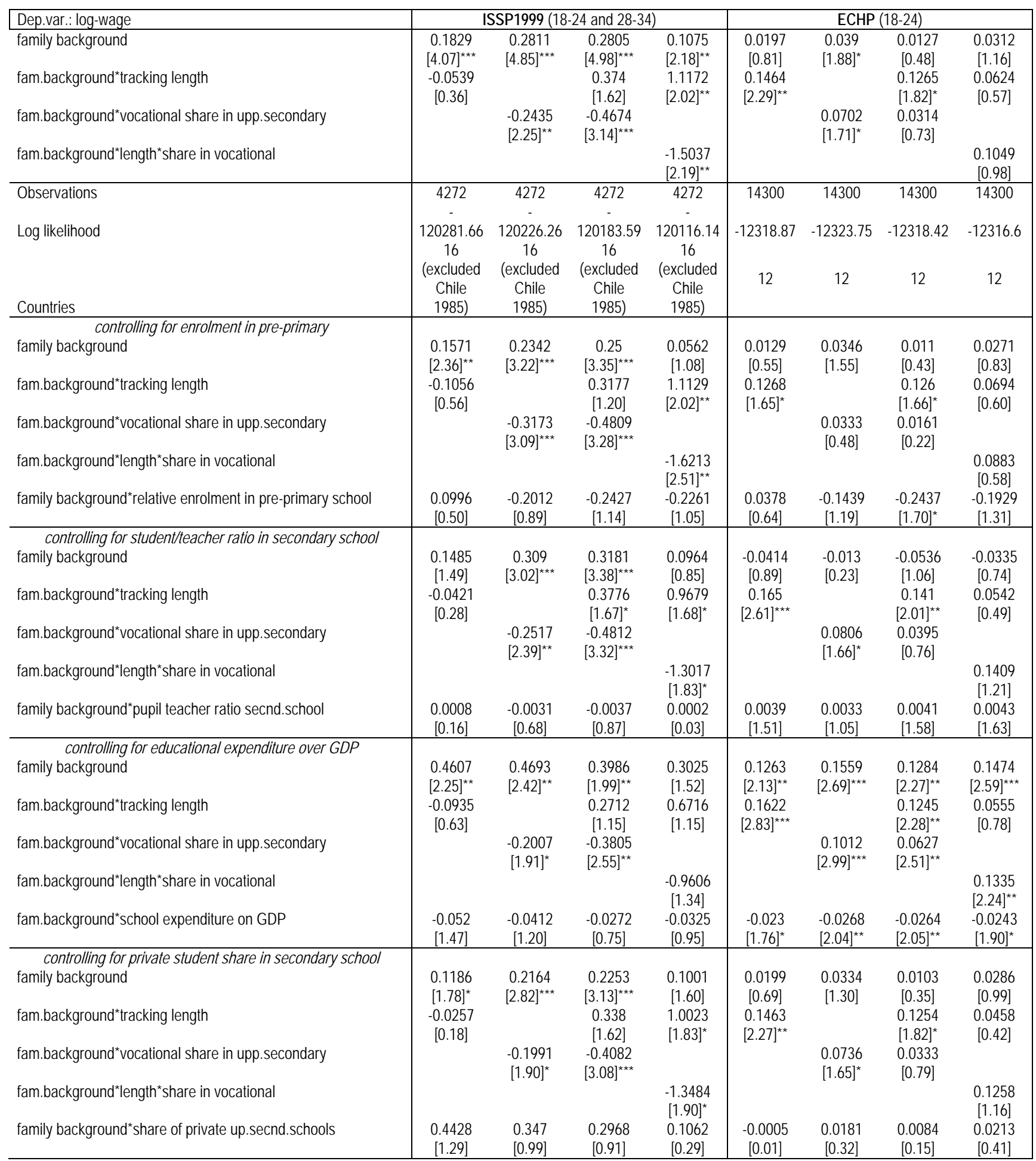


Table 10 - Inequality in earnings distribution (ols)

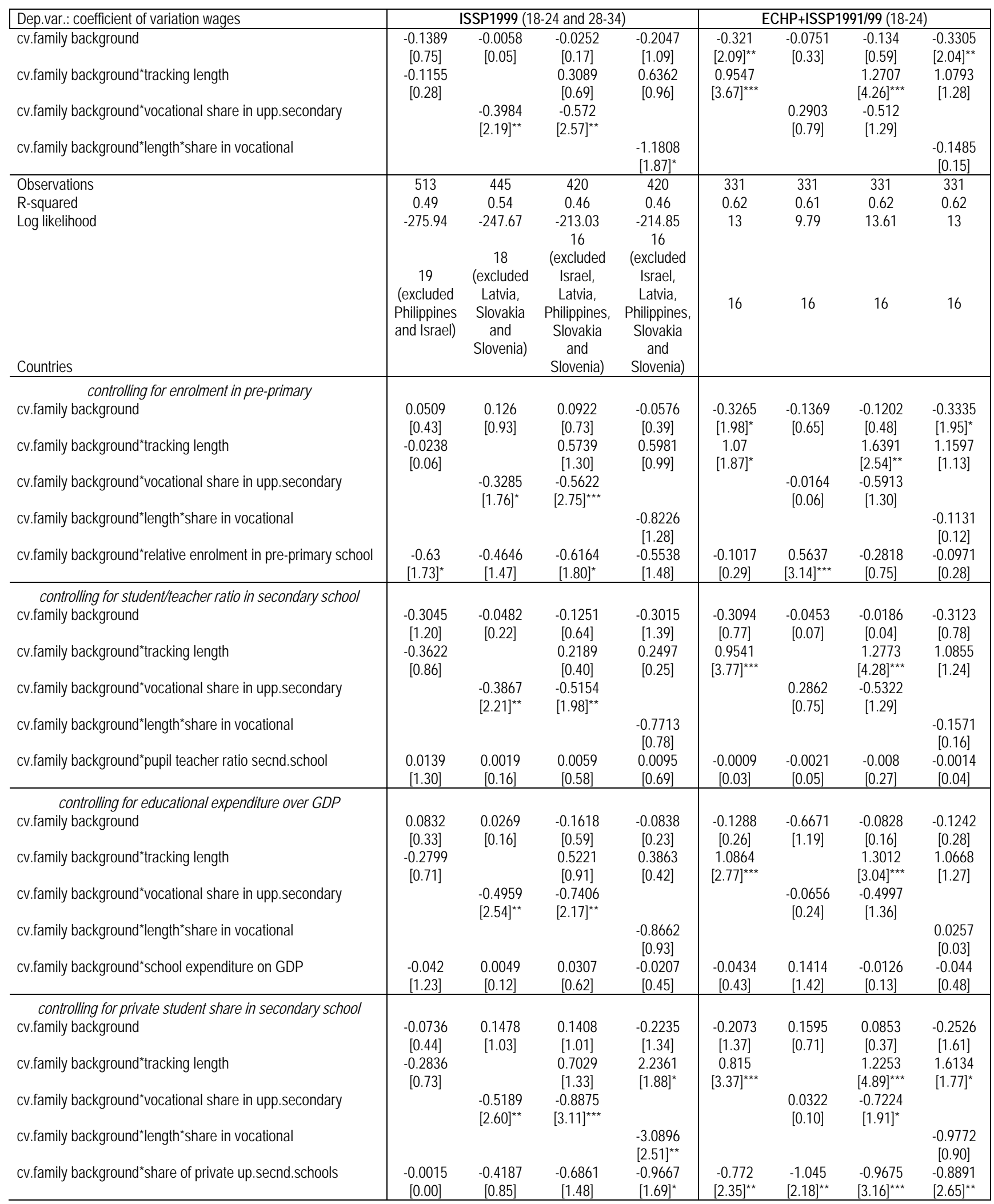


Table 11 - Determinants of competences - IALS sample (ols)

\begin{tabular}{|c|c|c|c|c|}
\hline Dep.var.: log competences (average across areas) & \multicolumn{4}{|c|}{ IALS (18-24 and 28-34) } \\
\hline $\begin{array}{l}\text { family background } \\
\text { fam.background*tracking length } \\
\text { fam.background*vocational share in upp.secondary } \\
\text { fam.background*length*share in vocational }\end{array}$ & $\begin{array}{c}0.1122 \\
{[5.81]^{\star \star \star}} \\
-0.0991 \\
{[2.50]^{\star \star}}\end{array}$ & $\begin{array}{c}0.1213 \\
{[5.11]^{\star \star \star}}\end{array}$ & $\begin{array}{c}0.1209 \\
{[5.06]^{\star \star \star}} \\
-0.0211 \\
{[0.62]} \\
-0.0687 \\
{[1.42]}\end{array}$ & $\begin{array}{c}0.1129 \\
{[5.48]^{\star \star \star}} \\
-0.1357 \\
{[0.94]}\end{array}$ \\
\hline $\begin{array}{l}\text { Observations } \\
\text { R-squared } \\
\text { Log likelihood } \\
\text { Countries }\end{array}$ & $\begin{array}{c}12195 \\
0.2 \\
2771.78 \\
17 \text { (excluded } \\
\text { Chile 1985) } \\
\end{array}$ & $\begin{array}{c}12195 \\
0.2 \\
2781.48 \\
17 \text { (excluded } \\
\text { Chile 1985) } \\
\end{array}$ & $\begin{array}{c}12195 \\
0.2 \\
2782.04 \\
17 \text { (excluded } \\
\text { Chile 1985) } \\
\end{array}$ & $\begin{array}{c}12195 \\
0.2 \\
2772.05 \\
17 \text { (excluded } \\
\text { Chile 1985) } \\
\end{array}$ \\
\hline $\begin{array}{l}\text { controlling for enrolment in pre-primary } \\
\text { family background } \\
\text { fam.background*tracking length } \\
\text { fam.background*vocational share in upp.secondary } \\
\text { fam.background*lengthshare in vocational } \\
\text { family background*relative enrolment in pre-primary school }\end{array}$ & $\begin{array}{c}0.1029 \\
{[6.13]^{\star \star \star}} \\
-0.1168 \\
{[1.78]^{\star}}\end{array}$ & $\begin{array}{c}-0.0788 \\
{[1.88]^{\star}}\end{array}$ & $\begin{array}{l}0.1236 \\
{[5.20]^{\star \star \star}} \\
-0.0129 \\
{[0.27]} \\
-0.072 \\
{[1.75]^{\star}}\end{array}$ & $\begin{array}{c}-0.0033 \\
{[0.02]} \\
0.0379 \\
{[0.51]}\end{array}$ \\
\hline $\begin{array}{l}\text { controlling for student/teacher ratio in secondary school } \\
\text { family background } \\
\text { fam.background*tracking length } \\
\text { fam.background*vocational share in upp.secondary } \\
\text { fam.background*lengthshare in vocational } \\
\text { family background*pupil teacher ratio secnd.school }\end{array}$ & $\begin{array}{c}0.0831 \\
{[2.81]^{\star \star \star}} \\
-0.0961 \\
{[2.50]^{\star \star}}\end{array}$ & $\begin{array}{l}-0.0806 \\
{[2.16]^{\star \star}}\end{array}$ & $\begin{array}{l}0.1019 \\
{[2.26]^{\star *}} \\
-0.0225 \\
{[0.63]} \\
-0.0657 \\
{[1.33]} \\
\\
\\
0.0013 \\
{[0.51]}\end{array}$ & $\begin{array}{c}0.084 \\
{[2.74]^{\star \star \star}} \\
-0.1317 \\
{[0.94]}\end{array}$ \\
\hline $\begin{array}{l}\text { controlling for educational expenditure over GDP } \\
\text { family background } \\
\text { fam.background*tracking length } \\
\text { fam.background*vocational share in upp.secondary } \\
\text { fam.background*length*share in vocational } \\
\text { fam.background*school expenditure on GDP }\end{array}$ & $\begin{array}{c}0.1384 \\
{[3.13]^{\star \star \star}} \\
-0.0976 \\
{[2.37]^{\star \star}}\end{array}$ & $\begin{array}{l}0.1154 \\
{[2.51]^{\star \star}} \\
-0.0832 \\
{[2.23]^{\star \star}}\end{array}$ & $\begin{array}{c}0.1196 \\
{[2.52]^{\star \star}} \\
-0.0207 \\
{[0.55]} \\
-0.0691 \\
{[1.31]}\end{array}$ & $\begin{array}{l}0.0386 \\
{[0.26]} \\
-0.005 \\
{[0.59]}\end{array}$ \\
\hline $\begin{array}{l}\text { controlling for private student share in secondary school } \\
\text { family background } \\
\text { fam.background*tracking length } \\
\text { fam.background*vocational share in upp.secondary } \\
\text { fam.background*lengthshare in vocational } \\
\text { family background*share of private up.secnd.schools }\end{array}$ & $\begin{array}{c}0.1197 \\
{[5.69]^{\star \star \star}} \\
-0.0999 \\
{[2.54]^{\star \star}}\end{array}$ & $\begin{array}{c}0.1256 \\
{[5.10]^{\star \star \star}}\end{array}$ & $\begin{array}{c}0.1256 \\
{[5.10]^{\star \star \star}} \\
-0.0332 \\
{[0.94]} \\
-0.0586 \\
{[1.24]}\end{array}$ & $\begin{array}{c}-0.0705 \\
{[0.47]} \\
-0.0499 \\
{[3.02]^{\star \star \star}} \\
\end{array}$ \\
\hline
\end{tabular}

Weighed - Robust standard errors clustered by country $\times$ wave - t statistics in brackets -

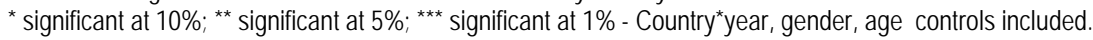


Table 12 - Inequality in competences distribution (ols)

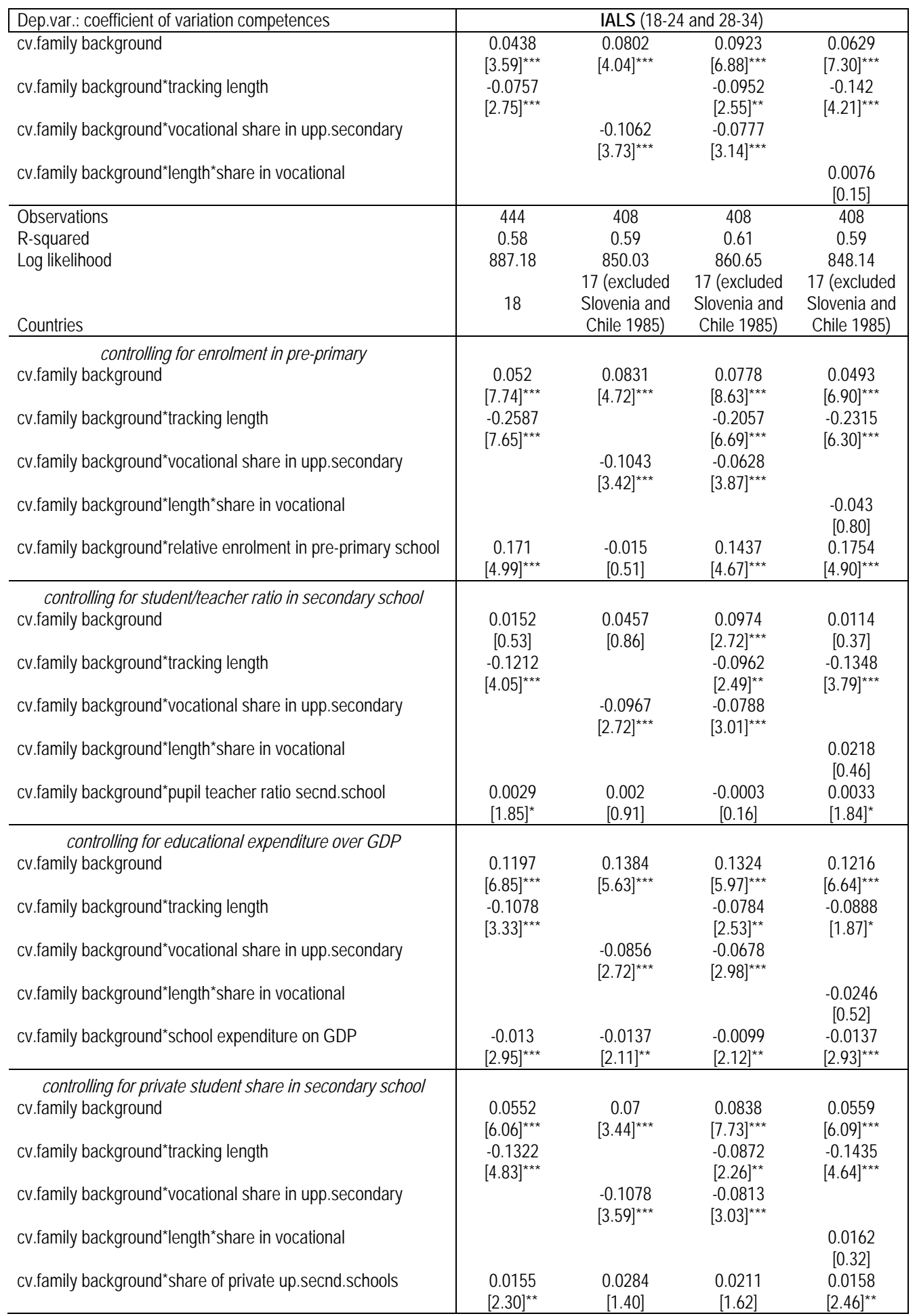

Weighed - Robust standard errors clustered by country×wave - z statistics in brackets -

* significant at 10\%; ** significant at 5\%; ${ }^{\star \star *}$ significant at $1 \%$ - Country*year, gender, age controls included. 
Table 13 - Probability of accessing on-the-job training (probit marginal effect)

\begin{tabular}{|c|c|c|c|c|c|c|c|c|}
\hline Dep.var.: 1=use of training & & IALS (18-2 & and 28-34) & & & ECHP & 18-24) & \\
\hline $\begin{array}{l}\text { family background } \\
\text { fam.background*tracking length } \\
\text { fam.background*vocational share in upp.secondary } \\
\text { fam.background*length*share in vocational }\end{array}$ & $\begin{array}{c}0.188 \\
{[8.28]^{\star \star \star}} \\
-0.1295 \\
{[1.39]}\end{array}$ & $\begin{array}{c}0.1945 \\
{[8.36]^{\star \star \star}} \\
\\
-0.0967 \\
{[1.63]}\end{array}$ & $\begin{array}{c}0.1935 \\
{[8.25]^{\star \star \star}} \\
-0.073 \\
{[0.42]} \\
-0.0488 \\
{[0.47]}\end{array}$ & $\begin{array}{c}0.1888 \\
{[8.30]^{\star \star \star}} \\
-0.1729 \\
{[0.60]} \\
\\
\\
0.0583 \\
{[0.14]}\end{array}$ & $\begin{array}{c}0.0073 \\
{[0.57]} \\
-0.0635 \\
{[1.97]^{\star \star}}\end{array}$ & $\begin{array}{c}0.0005 \\
{[0.03]} \\
\\
-0.032 \\
{[1.01]}\end{array}$ & $\begin{array}{c}0.0105 \\
{[0.64]} \\
-0.0579 \\
{[1.73]^{\star}} \\
-0.0109 \\
{[0.39]}\end{array}$ & $\begin{array}{c}0.0015 \\
{[0.11]} \\
-0.0168 \\
{[0.32]}\end{array}$ \\
\hline $\begin{array}{l}\text { Observations } \\
\text { Pseudo R-squared } \\
\text { Log likelihood }\end{array}$ & $\begin{array}{c}11146 \\
0.11 \\
-6791.6 \\
17 \\
\text { (excluded } \\
\text { Chile } \\
1985 \text { ) } \\
\end{array}$ & $\begin{array}{c}11146 \\
0.11 \\
-6791.77 \\
17 \\
\text { (excluded } \\
\text { Chile } \\
1985) \\
\end{array}$ & $\begin{array}{c}11146 \\
0.11 \\
-6790.99 \\
17 \\
\text { (excluded } \\
\text { Chile } \\
1985) \\
\end{array}$ & $\begin{array}{c}11146 \\
0.11 \\
-6791.55 \\
17 \\
\text { (excluded } \\
\text { Chile } \\
1985 \text { ) } \\
\end{array}$ & $\begin{array}{c}14892 \\
0.12 \\
-5845\end{array}$ & $\begin{array}{c}14892 \\
0.12 \\
-5847.58\end{array}$ & $\begin{array}{c}14892 \\
0.12 \\
-5844.86\end{array}$ & $\begin{array}{c}14892 \\
0.12 \\
-5844.3\end{array}$ \\
\hline $\begin{array}{l}\text { controlling for enrolment in pre-primary } \\
\text { family background } \\
\text { fam.background*tracking length } \\
\text { fam.background*vocational share in upp.secondary } \\
\text { fam.background*lengthshare in vocational } \\
\text { family background*relative enrolment in pre-primary school }\end{array}$ & $\begin{array}{c}0.156 \\
{[4.68]^{\star \star \star}} \\
-0.1879 \\
{[1.87]^{\star}}\end{array}$ & $\begin{array}{c}0.1892 \\
{[4.84]^{\star \star \star}} \\
-0.1008 \\
{[2.08]^{\star \star}}\end{array}$ & $\begin{array}{c}0.1574 \\
{[2.75]^{\star \star \star}} \\
-0.1808 \\
{[0.69]} \\
-0.0049 \\
{[0.03]}\end{array}$ & $\begin{array}{c}0.149 \\
{[4.61]^{\star \star *}} \\
-0.0919 \\
{[0.31]} \\
\\
\\
-0.1409 \\
{[0.33]} \\
0.1459 \\
{[1.29]}\end{array}$ & $\begin{array}{c}0.0093 \\
{[0.56]} \\
-0.0594 \\
{[2.02]^{\star \star}}\end{array}$ & $\begin{array}{c}0.0017 \\
{[0.10]} \\
\\
-0.0223 \\
{[0.61]}\end{array}$ & $\begin{array}{c}0.0107 \\
{[0.63]} \\
-0.0574 \\
{[1.82]^{*}} \\
-0.0093 \\
{[0.25]}\end{array}$ & $\begin{array}{l}-0.0012 \\
{[0.05]} \\
-0.0129 \\
{[0.21]} \\
\\
-0.0685 \\
{[0.95]} \\
0.0081 \\
{[0.20]}\end{array}$ \\
\hline $\begin{array}{l}\text { controlling for studentteacher ratio in secondary school } \\
\text { family background } \\
\text { fam.background*tracking length } \\
\text { fam.background*vocational share in upp.secondary } \\
\text { fam.background*length*share in vocational } \\
\text { family background*pupil teacher ratio secnd.school }\end{array}$ & $\begin{array}{c}0.3233 \\
{[3.11]^{\star \star \star}} \\
-0.1432 \\
{[1.50]}\end{array}$ & $\begin{array}{c}0.3472 \\
{[3.21]^{\star \star \star}} \\
\\
-0.1128 \\
{[1.98]^{\star \star}}\end{array}$ & $\begin{array}{c}0.3433 \\
{[3.35]^{\star \star \star}} \\
-0.0592 \\
{[0.35]} \\
-0.0736 \\
{[0.82]}\end{array}$ & $\begin{array}{c}0.3243 \\
{[3.16]^{\star \star \star}} \\
-0.1896 \\
{[0.64]} \\
\\
\\
0.0622 \\
{[0.14]} \\
-0.0098 \\
{[1.42]}\end{array}$ & $\begin{array}{c}-0.0028 \\
{[0.12]} \\
-0.0599 \\
{[1.79]^{\star}}\end{array}$ & $\begin{array}{c}-0.0146 \\
{[0.48]} \\
\\
-0.0274 \\
{[0.84]}\end{array}$ & $\begin{array}{c}0.001 \\
{[0.04]} \\
-0.0557 \\
{[1.66]^{\star}} \\
-0.009 \\
{[0.31]}\end{array}$ & $\begin{array}{c}-0.0045 \\
{[0.19]} \\
-0.0177 \\
{[0.33]} \\
\\
-0.0548 \\
{[0.92]} \\
0.0004 \\
{[0.32]}\end{array}$ \\
\hline $\begin{array}{l}\text { controlling for educational expenditure over GDP } \\
\text { family background } \\
\text { fam.background*tracking length } \\
\text { fam.backgroundvocational share in upp.secondary } \\
\text { fam.background*lengthshare in vocational } \\
\text { fam.background*school expenditure on GDP }\end{array}$ & $\begin{array}{c}0.3554 \\
{[4.38]^{\star \star \star}} \\
-0.1191 \\
{[1.30]}\end{array}$ & $\begin{array}{c}0.3306 \\
{[3.76]^{\star \star \star}}\end{array}$ & $\begin{array}{c}0.3557 \\
{[4.49]^{\star \star \star}} \\
-0.1205 \\
{[0.71]} \\
0.0012 \\
{[0.01]}\end{array}$ & $\begin{array}{c}0.3557 \\
{[4.43]^{\star \star \star}} \\
-0.1093 \\
{[0.53]} \\
\\
-0.0131 \\
{[0.04]} \\
-0.0333 \\
{[2.09]^{\star \star}}\end{array}$ & $\begin{array}{c}0.0392 \\
{[1.39]} \\
-0.0627 \\
{[1.81]^{\star}}\end{array}$ & $\begin{array}{c}0.0237 \\
{[0.87]} \\
\\
-0.0241 \\
{[0.71]}\end{array}$ & $\begin{array}{c}0.0392 \\
{[1.37]} \\
-0.0628 \\
{[1.72]^{*}} \\
0.0003 \\
{[0.01]}\end{array}$ & $\begin{array}{c}0.0321 \\
{[1.16]} \\
-0.0268 \\
{[0.48]} \\
\\
-0.0453 \\
{[0.78]} \\
-0.0061 \\
{[1.20]}\end{array}$ \\
\hline $\begin{array}{l}\text { controlling for private student share in secondary school } \\
\text { family background } \\
\text { fam.background*tracking length } \\
\text { fam.background*vocational share in upp.secondary } \\
\text { fam.background*length*share in vocational } \\
\text { family background*share of private up.secnd.schools }\end{array}$ & $\begin{array}{c}0.2 \\
{[8.71]^{\star \star \star}} \\
-0.1285 \\
{[1.38]}\end{array}$ & $\begin{array}{c}0.2031 \\
{[8.52]^{\star \star \star}} \\
\\
-0.0926 \\
{[1.53]}\end{array}$ & $\begin{array}{c}0.2029 \\
{[8.41]^{\star \star *}} \\
-0.092 \\
{[0.55]} \\
-0.0316 \\
{[0.32]}\end{array}$ & $\begin{array}{c}0.1996 \\
{[8.54]^{\star \star \star}} \\
-0.0162 \\
{[0.05]}\end{array}$ & $\begin{array}{c}-0.0067 \\
{[0.39]} \\
-0.0603 \\
{[2.09]^{\star \star}}\end{array}$ & $\begin{array}{c}-0.0181 \\
{[0.82]} \\
\\
-0.0186 \\
{[0.59]}\end{array}$ & $\begin{array}{c}-0.0085 \\
{[0.38]} \\
-0.0629 \\
{[2.27]^{\star *}} \\
0.0052 \\
{[0.19]}\end{array}$ & $\begin{array}{c}-0.0065 \\
{[0.40]} \\
-0.0627 \\
{[1.35]}\end{array}$ \\
\hline
\end{tabular}

Weighed - Robust standard errors clustered by country $\times$ wave $-\mathrm{z}$ statistics in brackets -

* significant at 10\%; ** significant at 5\%; ${ }^{* *}$ significant at $1 \%$ - Country*year, gender, age controls included. 
Table 14 - Summary table for empirical results

\begin{tabular}{|c|c|c|c|c|c|c|c|}
\hline & $\begin{array}{c}\text { parental } \\
\text { background }\end{array}$ & $\begin{array}{c}\text { parental } \\
\text { background } \\
\text { tracking length }\end{array}$ & $\begin{array}{c}\text { parental } \\
\text { background* } \\
\text { share in } \\
\text { vocational } \\
\end{array}$ & $\begin{array}{c}\text { parental } \\
\text { background* } \\
\text { pre-primary } \\
\text { enrolment } \\
\end{array}$ & $\begin{array}{c}\text { parental } \\
\text { background* } \\
\text { student/teacher } \\
\text { ratio }\end{array}$ & $\begin{array}{c}\text { parental } \\
\text { background* } \\
\text { educational } \\
\text { expenditure } \\
\end{array}$ & $\begin{array}{c}\text { parental } \\
\text { background* } \\
\text { share in private } \\
\text { schools } \\
\end{array}$ \\
\hline \multicolumn{8}{|c|}{ educational attainment } \\
\hline probability of drop-out & - & - & & & & & \\
\hline probability of college & + & + & - & & & & \\
\hline probability of employment & - & - & + & & & & \\
\hline earnings & + & + & - & & & & \\
\hline earnings inequality & & + & - & & & & \\
\hline \multicolumn{8}{|c|}{ life-long opportunities } \\
\hline literacy & + & - & - & & & & \\
\hline
\end{tabular}


Table 15 - Determinants of competences - PISA sample (ols)

\begin{tabular}{|c|c|c|c|c|c|c|c|c|}
\hline & \multicolumn{4}{|c|}{$\begin{array}{c}\text { PISA } 2003 \\
\text { (full sample } 32 \text { countries) }\end{array}$} & \multicolumn{4}{|c|}{$\begin{array}{c}\text { PISA } 2003 \\
\text { (sample comparable to IALS } 14 \text { countries) }\end{array}$} \\
\hline $\begin{array}{l}\text { family background } \\
\text { fam.background*tracking length } \\
\text { fam.background*vocational share in upp.secondary } \\
\text { fam.background*tracking index }\end{array}$ & $\begin{array}{c}0.0612 \\
{[9.67]^{\star \star \star}} \\
0.0326 \\
{[1.76]^{\star}}\end{array}$ & $\begin{array}{c}0.0672 \\
{[20.31]^{\star \star *}}\end{array}$ & $\begin{array}{c}0.0617 \\
{[8.73]^{\star \star \star}} \\
0.034 \\
{[1.76]^{\star}} \\
-0.0026 \\
{[0.17]}\end{array}$ & $\begin{array}{c}0.0624 \\
{[10.81]^{\star \star \star}} \\
0.0075 \\
{[0.41]}\end{array}$ & $\begin{array}{c}0.066 \\
{[13.97]^{\star \star \star}} \\
0.0354 \\
{[2.39]^{\star \star}}\end{array}$ & $\begin{array}{c}0.0699 \\
{[29.24]^{\star \star \star}}\end{array}$ & $\begin{array}{c}0.0677 \\
{[17.02]^{\star \star \star}} \\
0.0511 \\
{[2.55]^{\star \star}} \\
-0.018 \\
{[1.04]}\end{array}$ & $\begin{array}{c}0.0665 \\
{[15.19]^{\star \star \star}} \\
0.0015 \\
{[0.03]}\end{array}$ \\
\hline $\begin{array}{l}\text { Observations } \\
\text { R-squared } \\
\text { Log likelihood } \\
\text { Countries }\end{array}$ & $\begin{array}{c}216974 \\
0.22 \\
65633.76 \\
32\end{array}$ & $\begin{array}{c}212615 \\
0.22 \\
64230.27 \\
32\end{array}$ & $\begin{array}{c}212615 \\
0.22 \\
64282.54 \\
32\end{array}$ & $\begin{array}{c}212615 \\
0.22 \\
64308.15 \\
32\end{array}$ & \begin{tabular}{|c}
75388 \\
0.09 \\
21990.14 \\
14
\end{tabular} & $\begin{array}{c}75388 \\
0.09 \\
21961.79 \\
14\end{array}$ & $\begin{array}{c}75388 \\
0.09 \\
21995.66 \\
14\end{array}$ & $\begin{array}{c}75388 \\
0.09 \\
21994.74 \\
14\end{array}$ \\
\hline $\begin{array}{l}\text { controlling for enrolment in pre-primary } \\
\text { family background } \\
\text { fam.background*tracking length } \\
\text { fam.background*vocational share in upp.secondary } \\
\text { fam.background*tracking index } \\
\text { family background*relative enrolment in pre-primary school }\end{array}$ & $\begin{array}{c}0.0552 \\
{[6.45]^{\star \star \star}} \\
0.0311 \\
{[1.69]}\end{array}$ & $\begin{array}{c}0.062 \\
{[8.58]^{\star * \star}} \\
\\
0.0067 \\
{[0.49]}\end{array}$ & $\begin{array}{c}0.0556 \\
{[6.74]^{\star \star \star}} \\
0.0354 \\
{[2.00]^{\star}} \\
-0.0084 \\
{[0.58]}\end{array}$ & $\begin{array}{c}0.0581 \\
{[6.70]^{\star \star \star}} \\
0.0112 \\
{[0.56]}\end{array}$ & $\begin{array}{c}0.0657 \\
{[2.92]^{\star \star}} \\
0.0347 \\
{[0.77]}\end{array}$ & $\begin{array}{c}0.0545 \\
{[4.71]^{\star \star \star}}\end{array}$ & $\begin{array}{c}0.0846 \\
{[2.52]^{\star \star}} \\
0.0936 \\
{[1.15]} \\
-0.0348 \\
{[1.43]}\end{array}$ & $\begin{array}{c}0.0764 \\
{[0.86]} \\
0.0245 \\
{[0.29]}\end{array}$ \\
\hline $\begin{array}{l}\text { controlling for student/teacher ratio in secondary school } \\
\text { family background } \\
\text { fam.background*tracking length } \\
\text { fam.background*vocational share in upp.secondary } \\
\text { fam.background*tracking index } \\
\text { family background*pupil teacher ratio secnd.school }\end{array}$ & $\begin{array}{c}0.0711 \\
{[9.53]^{\star \star \star}} \\
0.0372 \\
{[1.90]^{\star}}\end{array}$ & $\begin{array}{l}0.0706 \\
{[8.21]^{\star \star \star}}\end{array}$ & $\begin{array}{c}0.0828 \\
{[6.72]^{\star \star \star}} \\
0.0566 \\
{[2.66]^{\star \star}} \\
-0.0257 \\
{[1.43]}\end{array}$ & $\begin{array}{c}0.067 \\
{[7.16]^{\star \star \star}} \\
0.014 \\
{[0.41]}\end{array}$ & $\begin{array}{c}0.0229 \\
{[0.77]} \\
0.0428 \\
{[3.67]^{\star \star \star}}\end{array}$ & $\begin{array}{l}0.0504 \\
{[1.49]}\end{array}$ & $\begin{array}{l}0.0226 \\
{[0.67]} \\
0.0602 \\
{[5.18]^{\star \star \star}} \\
-0.0195 \\
{[1.32]}\end{array}$ & $\begin{array}{c}-0.0127 \\
{[0.13]} \\
0.0032 \\
{[1.12]} \\
\end{array}$ \\
\hline $\begin{array}{l}\text { controlling for educational expenditure over GDP } \\
\text { family background } \\
\text { fam.background*tracking length } \\
\text { fam.background*vocational share in upp.secondary } \\
\text { fam.background*tracking index } \\
\text { fam.background*school expenditure on GDP }\end{array}$ & $\begin{array}{c}0.0222 \\
{[1.00]} \\
0.04 \\
{[2.06]^{\star \star}}\end{array}$ & $\begin{array}{c}0.0596 \\
{[5.14]^{\star \star \star}}\end{array}$ & $\begin{array}{c}0.0222 \\
{[0.96]} \\
0.043 \\
{[2.35]^{\star \star}} \\
-0.005 \\
{[0.48]}\end{array}$ & $\begin{array}{l}0.0412 \\
{[1.72]^{\star}} \\
0.0125 \\
{[0.54]} \\
\\
\\
0.0477 \\
{[1.38]} \\
0.0007 \\
{[0.83]} \\
\end{array}$ & $\begin{array}{c}0.0279 \\
{[0.91]} \\
0.043 \\
{[3.19]^{\star \star \star}}\end{array}$ & $\begin{array}{c}-0.0005 \\
{[0.01]}\end{array}$ & $\begin{array}{c}0.053 \\
{[1.11]} \\
0.0496 \\
{[2.24]^{\star \star}} \\
-0.013 \\
{[0.49]}\end{array}$ & $\begin{array}{c}0.0152 \\
{[0.63]} \\
-0.0005 \\
{[0.01]}\end{array}$ \\
\hline $\begin{array}{l}\text { controlling for private student share in secondary school } \\
\text { family background } \\
\text { fam.background*tracking length } \\
\text { fam.background*vocational share in upp.secondary } \\
\text { fam.background*tracking index }\end{array}$ & $\begin{array}{c}0.0681 \\
{[14.11]^{\star \star \star}} \\
0.034 \\
{[2.59]^{\star \star}}\end{array}$ & $\begin{array}{c}0.0719 \\
{[26.34]^{\star \star *}}\end{array}$ & $\begin{array}{c}0.0671 \\
{[11.61]^{\star \star \star}} \\
0.0275 \\
{[1.98]^{\star}} \\
0.0125 \\
{[0.95]}\end{array}$ & $\begin{array}{c}0.0618 \\
{[3.38]^{\star \star \star}} \\
-0.0386 \\
{[3.61]^{\star \star \star}} \\
\end{array}$ & $\begin{array}{c}0.0707 \\
{[17.24]^{\star \star \star}} \\
0.0368 \\
{[3.52]^{\star \star \star}}\end{array}$ & $\begin{array}{c}0.0723 \\
{[17.82]^{\star \star \star}}\end{array}$ & $\begin{array}{c}0.0709 \\
{[15.82]^{\star \star \star}} \\
0.02 \\
{[0.62]} \\
0.0199 \\
{[0.57]}\end{array}$ & $\begin{array}{c}0.073 \\
{[24.79]^{\star \star \star}} \\
-0.0271 \\
{[0.54]}\end{array}$ \\
\hline
\end{tabular}


Table 16. Students' competences, by school types. PISA 2003. Countries with secondary vocational programmes

\begin{tabular}{l|cccc|c} 
& \multicolumn{4}{|c}{ median score of students in general schools/ } & fraction of \\
& median score of students in vocational schools & 15-year-old \\
& mathematics & reading & $\begin{array}{r}\text { scientific } \\
\text { knowledge }\end{array}$ & $\begin{array}{c}\text { problem } \\
\text { solving }\end{array}$ & in vocational \\
schools
\end{tabular}

Note: students are restricted to belong to the modal grade in the country (except Indonesia, Ireland and Luxemburg, where students in vocational are typically one or two years ahead of the modal class) 
Table 17. Choice of vocational or private schools (probit) - PISA 2003

\begin{tabular}{|c|c|c|c|c|c|c|c|c|}
\hline & $\begin{array}{c}1 \\
\text { vocational }\end{array}$ & $\begin{array}{c}2 \\
\text { vocational }\end{array}$ & $\begin{array}{c}3 \\
\text { vocational }\end{array}$ & $\begin{array}{c}4 \\
\text { vocational }\end{array}$ & $\begin{array}{c}5 \\
\text { private }\end{array}$ & $\begin{array}{c}6 \\
\text { private }\end{array}$ & $\begin{array}{c}7 \\
\text { private }\end{array}$ & $\begin{array}{c}8 \\
\text { private }\end{array}$ \\
\hline \multirow[t]{2}{*}{ male } & 0.0789 & 0.0744 & 0.0808 & 0.0803 & -0.0232 & -0.0229 & -0.0211 & -0.0209 \\
\hline & {$[2.29]^{\star \star}$} & {$[2.10]^{\star \star}$} & {$[2.24]^{\star \star}$} & {$[2.29]^{\star \star}$} & {$[2.42]^{\star \star}$} & {$[2.42]^{\star \star}$} & {$[2.07]^{\star \star}$} & {$[2.08]^{\star \star}$} \\
\hline \multirow[t]{2}{*}{ age } & 0.1189 & 0.1215 & 0.1248 & 0.1263 & 0.0128 & 0.0125 & 0.0124 & 0.0121 \\
\hline & {$[1.73]^{\star}$} & {$[1.82]^{\star}$} & {$[1.83]^{\star}$} & {$[1.84]^{\star}$} & {$[2.86]^{\star \star \star}$} & {$[2.82]^{\star \star \star}$} & {$[2.79]^{\star \star \star}$} & {$[2.76]^{\star \star \star}$} \\
\hline \multirow[t]{2}{*}{ low marks in mathematics } & 0.047 & 0.0765 & 0.0438 & 0.0744 & -0.0089 & -0.0142 & -0.0053 & -0.0099 \\
\hline & {$[1.85]^{\star}$} & {$[2.15]^{\star \star}$} & {$[1.89]^{*}$} & {$[2.54]^{\star \star}$} & {$[3.16]^{\star \star \star}$} & {$[7.97]^{\star \star *}$} & {$[2.16]^{\star *}$} & {$[4.29]^{\star \star \star}$} \\
\hline \multirow[t]{2}{*}{ family background } & -0.0957 & -0.0498 & -0.037 & 0.0156 & 0.041 & 0.0464 & 0.0216 & 0.0258 \\
\hline & {$[2.83]^{\star \star \star}$} & {$[1.65]^{\star}$} & {$[2.04]^{\star \star}$} & {$[0.71]$} & {$[3.20]^{\star \star \star}$} & {$[2.61]^{\star \star \star}$} & {$[2.85]^{\star \star \star}$} & {$[2.11]^{\star \star}$} \\
\hline \multirow[t]{2}{*}{ books at home } & -0.0005 & -0.0005 & -0.0004 & -0.0003 & 0.0001 & 0.0001 & 0 & 0 \\
\hline & {$[17.32]^{\star \star \star}$} & {$[5.44]^{\star \star \star}$} & {$[9.10]^{\star \star *}$} & {$[3.39]^{\star \star \star}$} & {$[4.18]^{\star \star \star}$} & {$[4.49]^{\star \star \star}$} & [1.24] & {$[1.71]^{\star}$} \\
\hline \multirow[t]{2}{*}{ intact family } & -0.0045 & -0.0066 & 0.0019 & 0.0027 & 0.0185 & 0.0186 & 0.0132 & 0.0134 \\
\hline & {$[0.27]$} & {$[0.40]$} & {$[0.13]$} & {$[0.18]$} & {$[2.05]^{\star \star}$} & {$[2.05]^{\star *}$} & [1.53] & [1.54] \\
\hline \multirow[t]{2}{*}{ speaking dialect at home } & 0.0709 & 0.0823 & 0.0339 & 0.044 & 0.0052 & 0.0059 & 0.0187 & 0.0192 \\
\hline & {$[1.47]$} & {$[1.83]^{\star}$} & {$[0.69]$} & {$[1.00]$} & {$[0.16]$} & {$[0.18]$} & {$[0.67]$} & {$[0.69]$} \\
\hline \multirow[t]{2}{*}{ foreign born } & 0.0212 & 0.0146 & 0.0006 & -0.0136 & -0.0348 & -0.035 & -0.0311 & -0.0314 \\
\hline & {$[0.91]$} & {$[0.59]$} & {$[0.02]$} & {$[0.71]$} & {$[8.65]^{\star \star *}$} & {$[9.90]^{\star \star \star}$} & {$[6.01]^{\star \star \star}$} & {$[6.95]^{\star \star \star}$} \\
\hline \multirow{2}{*}{ low marks in mathematics*length*voc.share } & & -0.2145 & & -0.2098 & & 0.0537 & & 0.0446 \\
\hline & & {$[2.17]^{\star \star}$} & & {$[2.26]^{\star *}$} & & {$[2.75]^{\star \star \star}$} & & {$[2.80]^{\star \star \star}$} \\
\hline \multirow[t]{2}{*}{ fam.background*length*voc.share } & & -0.2591 & & -0.3 & & -0.0471 & & -0.0354 \\
\hline & & {$[3.79]^{\star \star \star}$} & & {$[4.65]^{\star \star \star}$} & & {$[0.93]$} & & {$[0.79]$} \\
\hline books at home*length*voc.share & & $\begin{array}{c}-0.0001 \\
{[0.51]}\end{array}$ & & $\begin{array}{c}-0.0002 \\
{[0.65]}\end{array}$ & & $\begin{array}{l}0.0001 \\
{[0.62]}\end{array}$ & & $\begin{array}{c}0 \\
{[0.58]}\end{array}$ \\
\hline \multirow[t]{2}{*}{ Highest parental occupational status } & & & -0.0047 & -0.0048 & & & 0.001 & 0.001 \\
\hline & & & {$[2.98]^{\star \star \star}$} & {$[2.98]^{\star \star *}$} & & & {$[7.74]^{\star \star \star}$} & {$[7.92]^{\star \star \star}$} \\
\hline \multirow[t]{2}{*}{ Index of home possessions (WLE) } & & & -0.0428 & -0.0457 & & & 0.0194 & 0.0191 \\
\hline & & & {$[2.27]^{\star \star}$} & {$[2.57]^{\star *}$} & & & {$[2.18]^{\star \star}$} & {$[2.25]^{\star \star}$} \\
\hline Observations & 72860 & 74903 & 72860 & 72860 & 77532 & 77532 & 77532 & 77532 \\
\hline Pseudo R-squared & 0.12 & 0.12 & 0.14 & 0.14 & 0.19 & 0.19 & 0.21 & 0.21 \\
\hline Log likelihood & -44326.75 & -45447.93 & -43503.46 & -43295.97 & -20791.21 & -20775.38 & -20487.35 & -20477.44 \\
\hline
\end{tabular}

Robust standard errors in brackets - * significant at 10\%; ** significant at 5\%; ${ }^{* *}$ significant at $1 \%$ - Country dummies included. 
Figure 1 - Intergenerational pełsistence in education and tracking

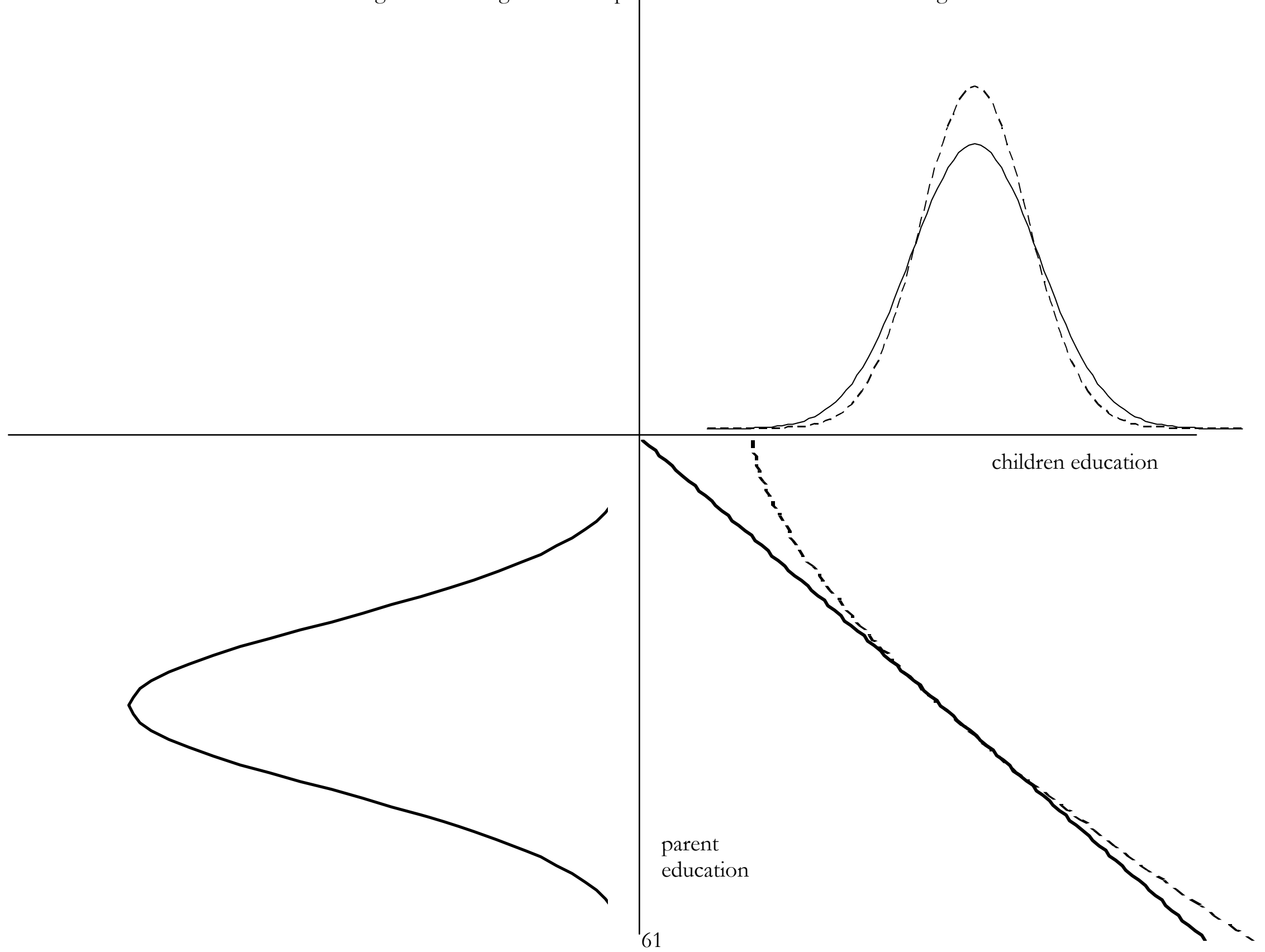




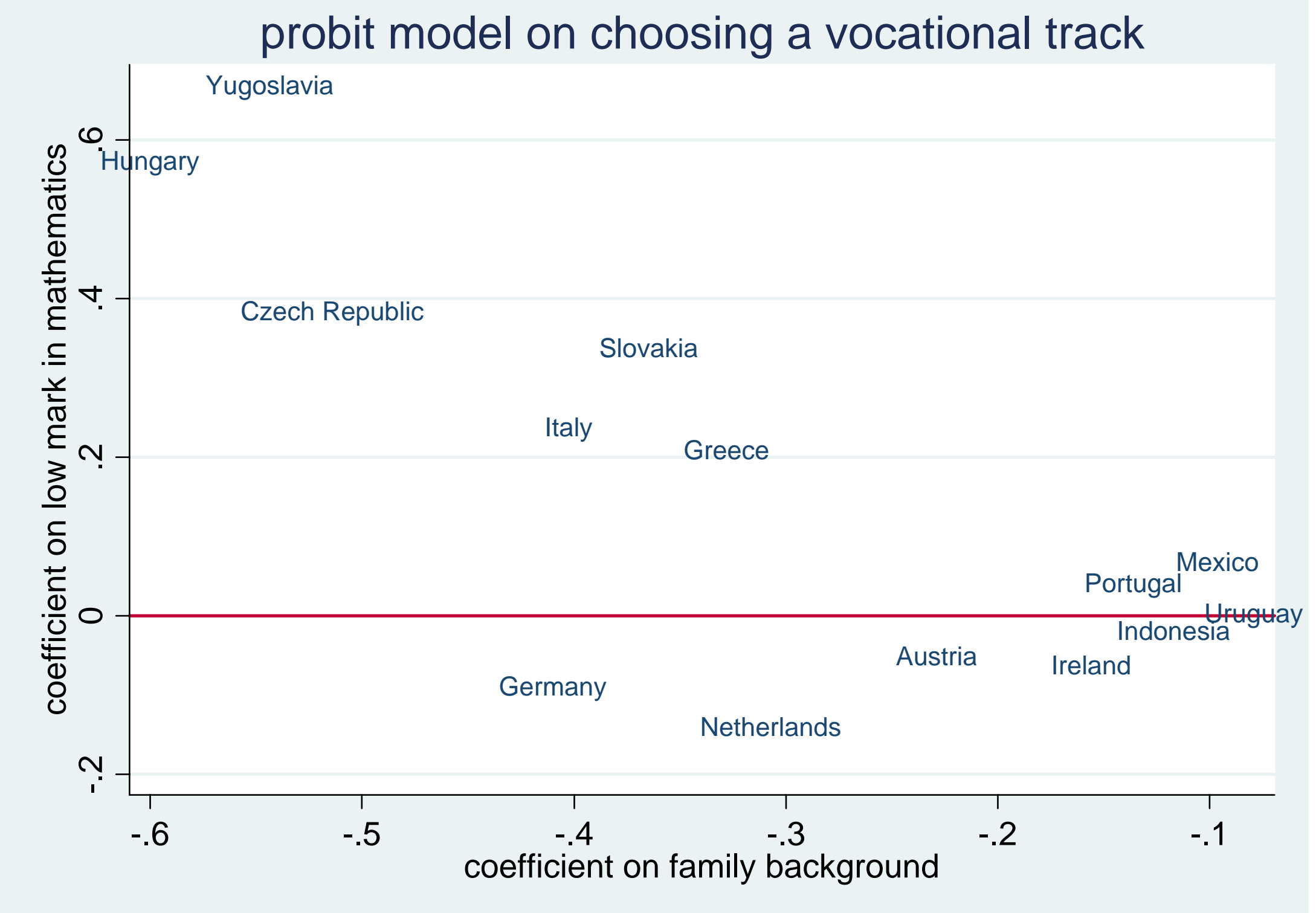

